\title{
11. OLIGOCENE TO HOLOCENE MASS-TRANSPORT DEPOSITS OF THE NEW JERSEY CONTINENTAL MARGIN AND THEIR CORRELATION TO SEQUENCE BOUNDARIES ${ }^{1}$
}

\author{
Cecilia M.G. McHugh,,${ }^{2,3}$ John E. Damuth, ${ }^{4}$ Stefan Gartner, ${ }^{5}$ Miriam E. Katz, ${ }^{3}$ and Gregory S. Mountain ${ }^{3}$
}

\begin{abstract}
The styles of soft-sediment deformation, mineralogy, and biostratigraphy of mass-transport deposits recovered from Leg 150 drill sites (902-906) provide important new information on the erosional and sedimentary history of the New Jersey continental slope and rise, and on the relationship of mass-wasting processes to changes in relative sea level. Nine distinct sedimentary facies are recognized within these mass-transport deposits, which mainly represent muddy slumps and debris flows, and to a lesser extent, sandy mass flows. These sedimentary facies, coupled with the ages of their clast and matrix material, reveal source areas, transport mechanisms, and depositional processes, and the relative contribution of downslope transport to the evolution of the continental rise.

Mass-wasting deposits compose $10 \%-15 \%$ of the total sediment recovered beneath the continental slope at Sites 902,903 , and 904. Upper Miocene and Pleistocene debris flows and slumps frequently correlate to sequence boundaries beneath the upper paleoslope at Site 903, and to a lesser extent, beneath the middle paleoslope at Sites 902 and 904. In contrast, upper Oligocene to upper Miocene sands and sandy mass flows correlate to sequence boundaries beneath the middle paleoslope at Sites 902 and 904 and not beneath the upper paleoslope at Site 903. Mass flows at these sites document shelf and coastal plain erosion and sediment transport to the basin during glacioeustatic lowering. These observations suggest a correlation between mass-transport deposits and sequence boundaries. However, this correlation is complex because preservation of mass-wasting deposits appears to have been significantly influenced by the morphology and gradient of the existing paleoslope. In addition, mass-transport deposits also occur within sequences especially during the upper Miocene and Pleistocene.

Site 906 was drilled in the floor of modern Berkeley submarine canyon. The sedimentary facies recovered from the middle Miocene section document an episode of canyon excavation and infilling. The Berkeley and middle Miocene canyon fill facies are different from the mass-transport deposits that characterize intercanyon regions of the slope (they contain debris flows with clasts of diverse ages and multiple turbidites). The middle Miocene canyon cutting event apparently occurred very rapidly $(\sim 1.1 \mathrm{~m} . \mathrm{y}$.) during a single third-order sea-level cycle (13.5-12.4 Ma) and the mass-transport deposits at the base of the canyon fill rest upon a Type I sequence boundary, which forms the canyon floor.

Downslope transport of sediment via mass movements has episodically contributed to the evolution of the upper continental rise. At Site 905 on the continental rise, approximately $30 \mathrm{~m}$ of mass-transport deposits were accumulated during the middle Miocene. Benthic foraminifer assemblages indicate that some deposits originated in the upper slope. The lithology of the clasts in these deposits indicates they were derived from canyon excavation on the continental slope and the age of the matrix material ( 13.5 Ma) suggests these deposits may correspond to initiation of canyon cutting events as the middle Miocene canyon at slope Site 906. During the upper Miocene sediment transported to the continental rise was derived from intercanyon regions as revealed by similar age of the clasts and matrix material. Downslope transport to the upper continental rise was especially significant during the lower Pleistocene when $\sim 215 \mathrm{~m}$ of mass-transport deposits were delivered to Site 905 . The lithologies and ages of clasts and matrix in some slumps and debris flows indicate that these deposits resulted predominantly from canyoncutting episodes, and to a lesser extent from localized slope detachments in intercanyon areas.
\end{abstract}

\section{INTRODUCTION}

Sediments deposited on a continental margin can provide a record of the erosional and depositional events that reveal the formation and evolution of that margin (Margins Steering Committee Members, 1993). Recent technological advances in seafloor mapping, seismic imaging, and deep sampling now permit scientists to study the sedimentary record in increasing detail and to deduce the geologic history of a margin better. Extensive surveys and studies of the U.S. Atlantic continental margin offshore New Jersey have revealed a dynamic

Mountain, G.S., Miller, K.G., Blum, P., Poag, C.W., and Twichell, D.C. (Eds.), 1996. Proc. ODP, Sci. Results, 150: College Station, TX (Ocean Drilling Program).

${ }^{2}$ Department of Geology, Queens College, City University of New York, 65-30 Kissena Blvd., Flushing, NY 11367, U.S.A. cmmqc@qcvaxa.acc.qc.edu U.S.A.

Lamont-Doherty Earth Observatory of Columbia University, Palisades, NY 10964,

${ }^{4}$ Earth Resource and Environmental Center and Department of Geology, University of Texas at Arlington, P.O. Box 19049, Arlington, TX 76019, U.S.A.

sDepartment of Oceanography, Texas A\&M University, College Station, TX 77843, U.S.A. sedimentary system where episodes of sediment accumulation were interrupted by intervals of widespread erosion (Schlee et al., 1979; Robb et al., 1981; Schlee, 1981; Poag, 1985; Embley and Jacobi, 1986; Laine et al., 1986; Farre and Ryan, 1987; Poag and Mountain, 1987; Poag, Watts, et al., 1987). The modern continental slope is predominantly an erosional setting incised by downslope-trending (diporiented) features, such as submarine canyons (Farre and Ryan, 1987; McHugh et al., 1991, 1993; Pratson et al., 1994). Large-scale mass wasting has led to the formation of complex submarine-canyon systems with intricate networks of tributaries (Farre et al., 1983). Intercanyon regions have been deeply excavated with gullies, amphitheater-shaped detachment surfaces, and grooved terrain (Farre and Ryan, 1987; Robb et al., 1983). Buried unconformities and erosional surfaces have also been identified in seismic reflection profiles and form major sequence boundaries, which have been correlated across the shelf and slope (Miller et al., 1990; G.S. Mountain et al., unpubl. data; Greenlee at al., 1992; Mountain and Tucholke, 1985; Mountain, 1987; Miller et al., 1987; Poag and Mountain, 1987). The continental rise is a thick depositional apron extending from the base of the continental slope, and its surface is dissected by channels and littered 
A 77

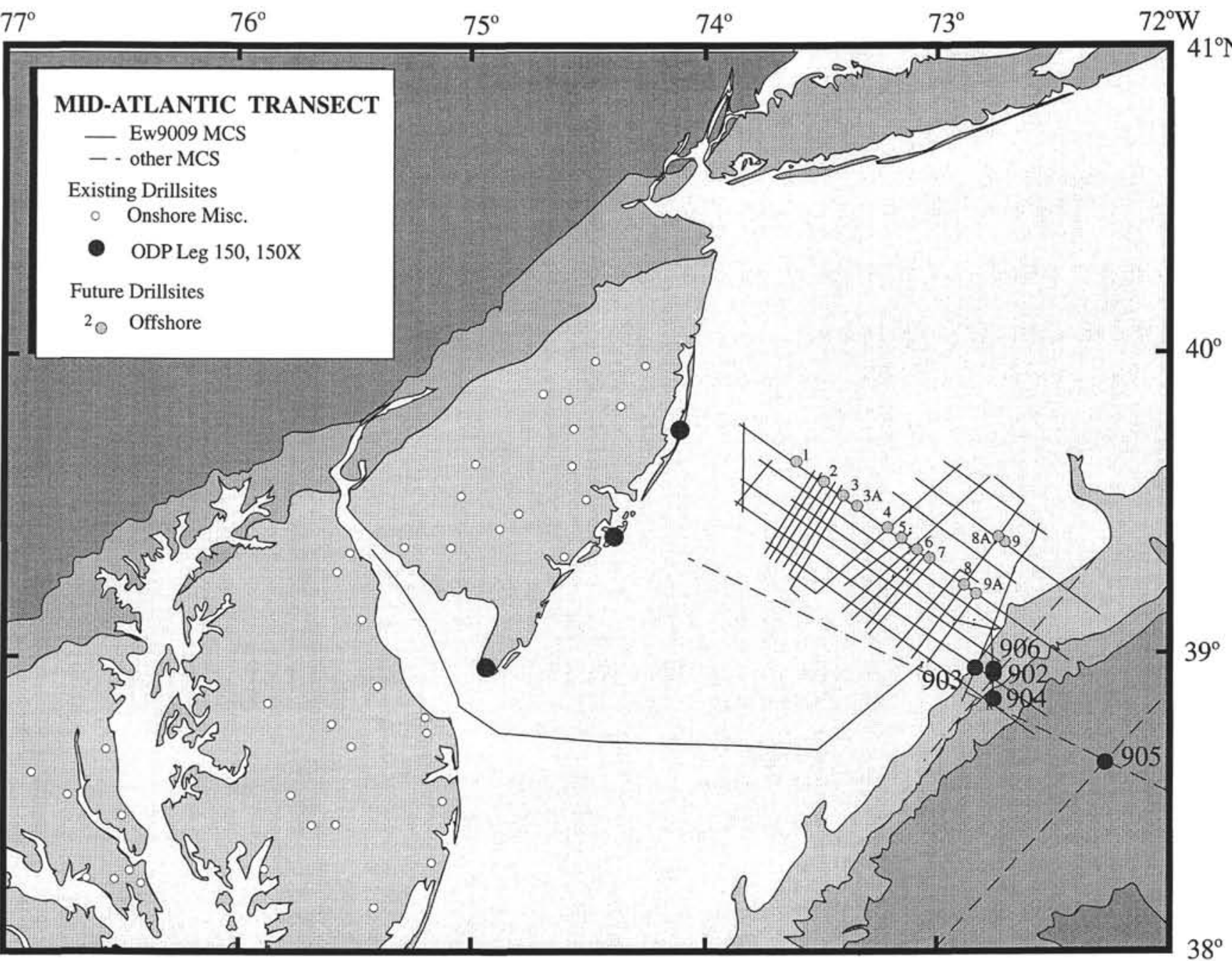

Figure 1. A. Location of the New Jersey continental margin multichannel seismic (MCS) profiles and Leg 150 drill sites (902-906). B. SeaBeam bathymetry of the New Jersey upper and middle slopes in the vicinity of Sites 902-904 and 906 showing major submarine canyon systems, DSDP Site 612, Cost B3 well, and Ewing 9009 seismic Lines 1005 and 1027 (dashed lines).

with displaced blocks (Poag, Watts, et al., 1987; Farre and Ryan, 1987; Mountain, 1987; Schlee and Robb, 1991). Analyses of regional seismic reflection profiles indicate that the sediments of the rise were deposited by both downslope and parallel-to-slope depositional processes (Mountain and Tucholke, 1985; Mountain, 1987). Although much is presently known about continental margins, especially the U.S. Atlantic margin, speculation continues as to the causal mechanisms for sediment failure, the history of sediment transport and deposition, and the timing of such events.

Vail and coworkers proposed a conceptual sea-level model based on seismic stratigraphic analysis to explain the processes responsible for the erosion, distribution, and accumulation of sediment on continental margins (Vail et al., 1977, 1991; Haq et al., 1987; Posamentier et al., 1988; Posamentier and Vail, 1988; Vail, 1987; Van Wagoner et al., 1990; Mitchum et al., 1993). In this model, accelerated sealevel lowering eventually exposes the continental shelf and permits intensified erosion and sediment transport to the slope and rise. Erosion on the shelf and upper slope leads to submarine-canyon incision and the development of prominent regional unconformities (i.e., sequence boundaries). Widespread mass wasting presumably occurs in association with the formation of these erosional unconformities and these events are expected to lead to extensive transport of sediments into the basin (lowstand systems tracts). In contrast, episodes of sediment deposition occur across the upper slope and shelf during times of sea-level rise (transgressive systems tract), highstand, and the beginning of sea-level fall (highstand systems tract). Although the Vail/Exxon conceptual model has been widely applied in some quarters, especially the petroleum industry, questions as to the timing of erosional and depositional events and control of facies deposition in response to sea-level cycles remains largely untested (Posamentier et al., 1988; Christie-Blick et al. 1990; Reynolds et al., 1991; Christie-Blick, 1991).

During Leg 150, a transect of five sites (902-906) was drilled: four on the slope and one on the upper continental rise (Fig. 1A, B). These holes provide an excellent opportunity to examine the indirect effects of relative sea-level changes on downslope sediment transport and deep-sea sedimentation patterns. The primary objective of the present study is to begin to evaluate the relationship between sealevel change and erosional and depositional events on a passive continental margin. To accomplish this objective, we conducted detailed studies that focus mainly on the styles of soft-sediment deformation, mineralogy, biostratigraphy, and depositional processes of mass- 


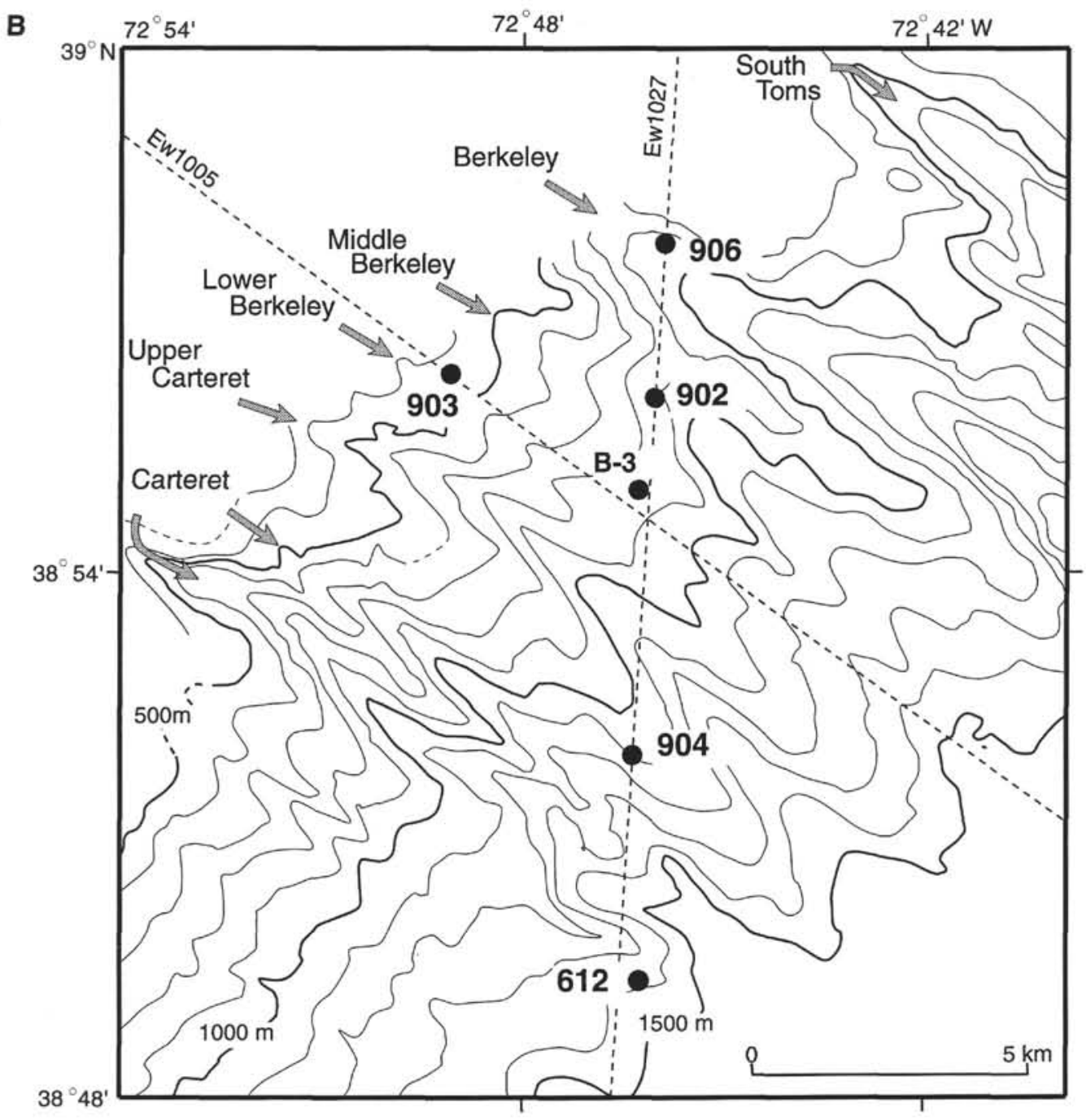

Figure 1 (continued).

transport deposits. The types of sedimentary facies present are described and classified, and a temporal correlation is established between sites based on seismic stratigraphy. Some of the mass-transport deposits sampled rest upon stratal surfaces or reflections on seismic profiles that are interpreted as sequence boundaries (Greenlee et al., 1992; G.S. Mountain et al., unpubl. data). These studies permit us to address (1) the source areas, transport mechanisms, and depositional processes of mass-wasting deposits that led to the construction and destruction of the continental slope, (2) the relative contribution and processes of downslope transport of sediment to the development of the continental rise, and (3) the timing of mass-wasting events and their correlation with eustatic sea-level fluctuations.

\section{METHODS OF SAMPLE ANALYSIS}

The matrix material and mud clasts of the mass-transport deposits recovered from all Leg 150 sites were sampled to study their provenance. The mass-wasting deposits used for seismic stratigraphic correlations in this study are the bottommost unit of the sequence located right above the unconformity as defined by Greenlee et al. (1992) and G.S. Mountain et al. (unpubl. data). The composition of the mud clasts within the mass-transport deposits was studied by X-ray dif- fraction analyses: bulk and clay mineralogy. The mineralogy was determined using the Phillips $\mathrm{X}$-ray diffractometer with $\mathrm{CuK} \alpha$ radiation (Ni filter). Instrument conditions were as follows: $40 \mathrm{kV}, 40 \mathrm{~mA}$, goniometer scan from $2^{\circ}$ to $60^{\circ}$, step size $=0.02^{\circ}$, count time $=0.2 \mathrm{~s}$, $0.1 \%$. Bulk sediments were crushed and mounted in random orientation in aluminum sample holders. The relative distribution of the identified minerals is plotted according to the intensity of their main diffraction peak. The minerals studied for bulk mineralogy and their respective main diffraction peaks are as follows: quartz $=3.34 \AA$, feldspar $=3.18-3.25 \AA$, amphibole $=8.4-8.5 \AA$, calcite $=3.03 \AA$, dolomite $=2.89 \AA$, siderite $=2.8 \AA$, pyrite $=2.71 \AA$, and graphite $=1.67$ $\AA$. Opal-A was identified by a very broad peak around $4 \AA$, and opalCT by a peak near $4.1 \AA$ (Kastner, 1981).

Samples were prepared for clay analyses by removing the carbonate present. This was accomplished by heating the crushed sample in a sodium acetate-acetic acid buffer at $\mathrm{pH} 5$. The $<2-\mu \mathrm{m}$ clay-sized fraction was separated by centrifugation. Preferred-orientation glass slides were prepared from the solution. Clay samples were analyzed in both the air-dried and ethylene-glycol-solvated conditions.

The clay mineral "groups" observed in this study (smectite, illite, glauconite, kaolinite, chlorite, and mixed layer illite/smectite) were identified by their characteristic basal X-ray diffraction maxima or peaks. Clays that expanded to a $17 \AA(001)$ peak upon glycolation 
were assigned to the smectite group. Illite, the micaceous clay mineral constituent of argillaceous sediment, was identified by basal reflections at $10,5,3.3$, and $2.5 \AA$, which are not affected by glycolation. Glauconite was differentiated from illite by its weak or nonexistent basal reflection at $5 \AA$. Mixed-layer smectite-illite was characterized by peaks of varying breadth between 10 and $14.2 \AA$. Chlorite was identified by the $14,7.1,4.72$, and $3.53 \AA$ reflections. Kaolinite reflections 7.2 and $3.57 \AA$ overlap the (002) and (004) chlorite peaks. Determination of their individual contributions is explained below.

Semiquantitative information about the relative proportion of clays present was obtained by measuring integrated peak areas above the background with a polar planimeter (Biscaye, 1965). Weighted peak areas were determined by relating the peak area of one mineral to other minerals present and to the total concentration. The glycolated areas of the 17 - $\AA$ peak of smectite were four times the 10 - $\AA$ peak area for illite and twice the $7-\AA$ peak area contributed by both kaolinite and chlorite. The individual kaolinite-chlorite contributions to the $7-\AA$ peak area were further resolved into separate components by determining the proportional fraction of each mineral from the total area under the kaolinite and chlorite $3.5-\AA$ peaks (Biscaye, 1965). The four weighted peak areas were summed. The percentage of each mineral was determined by multiplying the weighted peak area of each mineral by 100 and dividing it by the sum of the four weighted peak areas.

Petrographic thin sections were prepared from indurated clasts. The thin sections were stained with alizarin red and potassium ferricyanide for calcium carbonate and dolomite identification. Scanning electron microscope and electron diffraction X-ray analyses (SEM/ EDX) were conducted on selected clasts. The quantitative calcium carbonate content of each clast was estimated by coulometric analyses.

The ages of the clasts were determined from calcareous nannofossils using methods described in the Leg 150 Initial Reports volume. Benthic foraminifers were examined to determine paleobathymetry. The paleobathymetric zones and benthic foraminifer abundances used were also those described in the Leg 150 Initial Reports.

Seismic stratigraphic studies for Leg 150 initially used data collected by the USGS and Exxon Production Research (see "Seismic Stratigraphy" section, "Explanatory Notes" chapter in Mountain, Miller, Blum, et al., 1994). The sequence boundaries on these profiles were recognized on the basis of regional unconformities identified by top-discordant and base-discordant seismic reflection geometries (Mitchum et al., 1977). The sequence boundaries identified were related to those of Greenlee et al. (1988), who correlated them to the Haq et al. (1987) inferred global sea-level record. Additional seismic data were collected on cruise Ew9009 (G.S. Mountain, unpubl. data) and during Leg 150. Prominent seismic reflections and sequence boundaries previously identified beneath the continental shelf were traced to the slope using the Ew9009 seismic grid (Mountain, Miller, Blum, et al., 1994). In addition, several prominent new reflections were identified and named during Leg 150 and correlated to the Ew9009 profiles (Table 1). The seismic reflections were dated and correlated to sequence boundaries that had been previously identified.

\section{DEEP-MARINE GRAVITY-CONTROLLED SEDIMENTARY PROCESSES}

Deep-marine depositional processes are briefly discussed here to define and clarify terminology used in this report. Sediment failures generate a spectrum of gravity-driven processes whose end members are generally identified as slides, slumps, debris flows, and turbidity currents. Various classifications of these processes and their resulting deposits have been proposed and in this paper, we follow the terminology originally proposed by Varnes (1958), Dingle (1977) and Em- bley and Jacobi (1977) with slight modification by Shanmugam et al. (1994, 1995). Slumps and slides are sometimes not distinguished from each other in the literature (Woodcock, 1979) because both processes involve downslope movement of sediment as a coherent mass. However, in this paper we differentiate the two processes as follows. A slide is a mass or block that moves downslope on a planar glide plane or shear surface and shows essentially no internal deformation, whereas a slump is a block that moves downslope on a concave-up glide plane or shear surface (Dingle, 1977; Embley and Jacobi, 1977) and undergoes rotational movements causing minimal to substantial internal deformation. In summary, slides represent translational movements and slumps represent rotational movements along shear surfaces. Differentiation of slumps and slides based solely on seismic data is often impossible because the presence or degree of internal deformation is undetectable. However, when long, continuous cores through these deposits are available, slumps and slides can often be differentiated as explained below.

Although cores alone prohibit recognition of the types of glide planes, slump deposits can often be distinguished from slide deposits in cores by the presence of deformation features. Slump facies were identified in Leg 150 cores using the following criteria: (1) soft-sediment folds, (2) contorted or discordant bedding, (3) steeply dipping layers (up to $60^{\circ}$ ) with various orientations, (4) basal (primary) glide planes and shear zones, (5) internal (secondary) glide planes, (6) abrupt changes in lithology or fabric, (7) inclined dish structures, (8) brecciated zones, and (9) clastic injections (Helwig, 1970; Woodcock, 1976; Jacobi, 1976; Gawthorpe and Clemmey, 1985; Martinsen, 1989; Shanmugam et al., 1994, 1995).

If a slide or slump block continues to move downslope, mass disaggregation can result in mixing with water and transform these deposits into a debris flow, in which sediment is transported as an incoherent, viscous mass via plastic (laminar) flow. In debris flows, intergranular movements predominate over shear-surface movements. Debris-flow facies are characterized by (1) units with sharp upper and lower contacts, (2) floating or rafted mud and/or lithic clasts, (3) a planar clast fabric, (4) inverse grading of clasts, (5) basal shear zone, and (6) moderate to high matrix content (Johnson, 1970; Fisher, 1971; Hampton, 1972; Middleton and Hampton, 1973; Jacobi, 1976; Shanmugam and Benedict, 1978; Embley, 1980; Shanmugam et al., 1995).

If fluid content continues to increase as a debris flow moves downslope, the laminar, plastic flow may evolve into turbulent flows and form a fluidal turbidity current. In this paper, we follow the definition of turbidity currents in which sediment is supported by fluid turbulence (Middleton and Hampton, 1973). Deposits of turbidity currents (i.e., turbidites) are recognized by (1) normal size grading, (2) sharp basal contacts, (3) gradational upper contacts, and (4) Bouma divisions (Bouma, 1962; Middleton and Hampton, 1973).

\section{GEOLOGIC SETTING AND SEISMIC STRATIGRAPHY OF LEG 150 SITES}

The geologic setting and seismic stratigraphy of the Leg 150 drill sites (902-906) on the New Jersey continental slope and rise and the lithology of the cores are described in detail in the Initial Reports volume (Mountain, Miller, Blum, et al., 1994). The following is a very brief description for the purposes of this study. All continental slope sites (902-904) except for Site 906 were chosen to recover an especially complete and thick portion of the Oligocene to Holocene inter$\mathrm{val}$ and were located away from modern and ancient canyon thalwegs and other downslope transport pathways. This task was particularly difficult for the Pleistocene, where the slope is incised by numerous canyons and gullies.

The seismic stratigraphic interpretation of Sites 902-904 is based on Cruise Ew9009 MCS Lines 1027 and 1005, which provided direct ties from the slope to the adjacent continental shelf (Figs. 2, 3). Site 
Table 1. Tentative correlations of seismic reflectors at Site 903, New Jersey continental slope, Leg 150 (Mountain, Miller, Blum, et al., 1994).

\begin{tabular}{|c|c|c|c|c|}
\hline Name & Color & Stage & Age & Lithology \\
\hline $\mathrm{pl}^{\mathrm{a}}$ & Yellow & $\delta^{18} \mathrm{O}$ Stage $7 / 6$ transition $^{\mathrm{a}}$ & middle Pleistocene & Uncertain \\
\hline $\mathrm{p}^{\mathrm{a}}$ & Blue & $\delta^{18} \mathrm{O}$ Stage $9 / 8$ transition $^{\mathrm{a}}$ & middle Pleistocene & Facies 2 and 4 \\
\hline $\mathrm{p}^{\mathrm{a}}$ & Green & $\delta^{18} \mathrm{O}$ Stage 10 hiatus; Stage $11 / 10$ transition $^{a}$ & middle Pleistocene & Log density minimum \\
\hline $\mathrm{p}^{\mathrm{a}}$ & Purple & $\delta^{18} \mathrm{O}$ Stage $12.4 / 12.3$ transition $^{\mathrm{a}}$ & middle Pleistocene & Below Facies 1 and 2 -gamma peak \\
\hline $\mathrm{p5}^{\mathrm{a}}$ & Orange & $\delta^{18} \mathrm{O}$ Stage $13 / 12$ transition $^{\mathrm{a}}$ & middle Pleistocene & $\begin{array}{l}\text { Facies } 1 \text { and } 2 \text { - log and lab measured density } \\
\text { minimum }\end{array}$ \\
\hline$p 6^{\mathrm{a}}$ & Indigo & $\begin{array}{l}\text { Disconformity separating upper Pliocene } \\
\text { and Stage } 15^{a}\end{array}$ & $\begin{array}{l}\text { upper Pliocene/middle } \\
\text { Pleistocene }\end{array}$ & Facies 2 and 3 \\
\hline $\mathrm{m} 0.3$ & Yellow & Near base of $C 4 n$ & middle upper Miocene & Facies 2 \\
\hline $\mathrm{m} 0.5^{\mathrm{b}}$ & Red & C4Ar? & middle upper Miocene & Facies 2 \\
\hline $\mathrm{m} 1^{b}$ & Tuscan & C5r? & upper middle Miocene & Facies 1 and 2 \\
\hline $\mathrm{ml} .5^{\mathrm{c}}$ & Orange & C5r? & upper middle Miocene & Facies 1 and 2 \\
\hline $\mathrm{m} 2^{\mathrm{b}}$ & Yellow-2 & C5Ar? & upper middle Miocene & Below density maximum, at velocity maximum \\
\hline $\mathrm{m} 3^{b}$ & Blue & Older than C5Ar, NN7, and FO $G$. fohsi fohsi & middle middle Miocene & At core density maximum \\
\hline $\mathrm{m} 4^{\mathrm{b}}$ & Pink-2 & ?Near NN5/NN6 boundary & middle middle Miocene & Log velocity peak \\
\hline $\mathrm{m}^{\mathrm{b}}$ & Green & Near NN4/NN5 boundary; possibly upper NN4 & $\begin{array}{l}\text { near lower/middle Miocene } \\
\text { boundary }\end{array}$ & Facies 2 \\
\hline $\mathrm{m} 6^{\mathrm{c}}$ & Pink-3 & Unconformity NP25/NN2 & $\begin{array}{l}\text { near Oligocene/Miocene } \\
\text { boundary }\end{array}$ & $\begin{array}{l}\text { Hole 903C, uncertain poor recovery; Hole } \\
\text { 903D, no recovery }\end{array}$ \\
\hline $\mathrm{ol}^{\mathrm{C}}$ & Green-2 & Unconformity NP19-20/NP23 & upper Eocene/middle Oligocene & Facies 2 \\
\hline el & Yellow & Unconformity NP16/NP19-20 & middle/upper Eocene boundary & Not reached \\
\hline
\end{tabular}

"Based on GRAPE and magnetic susceptibility correlations to SPECMAP oxygen isotope time scale.

bPossibly equivalent to the shelf reflectors of this color (Greenlee et al., 1992).

'Possibly equivalent to the shelf reflectors of this color (G.S. Mountain et al., unpubl. data).

903 was drilled in an intercanyon region northeast of lower Berkeley Canyon and $2.2 \mathrm{~km}$ east-northeast of the thalweg of upper Carteret Canyon (Fig. 1A). Site 903 was drilled in $\sim 445 \mathrm{~m}$ of water depth on the upper continental slope; it is the shallowest of the four slope sites $(902,903,904$, and 906$)$. The 1150 -m-thick sedimentary section recovered is middle Eocene to late Pleistocene. At this as well as the other slope sites, the Eocene is characterized by pelagic carbonate deposition, whereas the Oligocene to Pleistocene sections are dominated by hemipelagic siliciclastic sedimentation. Seismic reflectors p1 through p6 were observed for the Pleistocene (Table 1). Reflectors $\mathrm{m} 0.3, \mathrm{~m} 0.5, \mathrm{~m} 1, \mathrm{~m} 1.5, \mathrm{~m} 2$ through $\mathrm{m} 5, \mathrm{~m} 5.2, \mathrm{~m} 5.4$, and $\mathrm{m} 6$ were correlated to the cores for the Miocene, and seismic reflector ol correlates to the contact between the upper Eocene biosiliceous chalks and Oligocene siliciclastics.

Site 902 was drilled on the upper-middle slope in $820 \mathrm{~m}$ of water depth near the southwest wall of middle Berkeley Canyon (Fig. 1A). The continental slope in the vicinity of Site 902 is incised with canyons and the topography of the region is relatively steep. The 740-mthick sedimentary sequence recovered at Site 902 is upper Eocene to Holocene. The upper Pleistocene and Holocene are 9 and $1 \mathrm{~m}$ thick, respectively. The lower Oligocene to Pleistocene section is $685 \mathrm{~m}$ thick and consists of siliciclastic sediment. The upper Eocene is $55 \mathrm{~m}$ thick and is composed of biosiliceous clayey chalks. Pleistocene seismic reflectors $\mathrm{p} 0$ through $\mathrm{p} 4$ were identified on profiles crossing or near Site 902 (Figs. 2, 3). Miocene seismic reflectors m0.5, m0.7, $\mathrm{m} 1$ through $\mathrm{m} 5, \mathrm{~m} 5.2, \mathrm{~m} 5.4, \mathrm{~m} 5.6$, and $\mathrm{m} 6$ were identified and correlated to Site 902 sediment, and seismic reflector o1, as at Site 903, was correlated to the contact between the upper Eocene biosiliceous chalks and Oligocene siliciclastics.

Site 904 was drilled on the lower middle slope in $1123 \mathrm{~m}$ of water depth in the north wall of Carteret Canyon (Fig. 1A). The Pleistocene topography at Site 904 is steeper than at the other slope sites. Because of erosional truncation and downlap, Oligocene to Pleistocene seismic correlations between Ew9009 Lines 1005 and 1027 at Site 904 are the least certain of the slope sites (Figs. 2, 3). Pleistocene seismic reflectors $\mathrm{p} 1$ through $\mathrm{p} 4$ and Miocene seismic reflectors $\mathrm{m} 0.7, \mathrm{~m} 1$ through $\mathrm{m} 3, \mathrm{~m} 5.2$, and $\mathrm{m} 6$ were tentatively identified. In contrast, seismic reflectors e1 and e 2 can be clearly correlated with the discomformable upper/middle Eocene boundary and with the top of the diagenetic horizon (Tucholke and Vogt, 1979). Seismic reflector ol, as at other slope sites, correlates to the contact between the upper Eocene biosiliceous chalks and Oligocene siliciclastics. A $570-\mathrm{m}-$ thick section of middle Eocene to the upper Pleistocene sediments was recovered at Site 904. The middle and upper Eocene sections are $227 \mathrm{~m}$ of biosiliceous chalks and porcellanites, which contain less clay than the Eocene sediments recovered from the upper slope. The upper Oligocene ( $30 \mathrm{~m}$ thick), Miocene ( $235 \mathrm{~m}$ thick), and the Pleistocene (106 m thick) are composed of siliciclastic sediment.

Site 906 was located on the middle continental slope at $\sim 923 \mathrm{~m}$ of water depth, and $3.3 \mathrm{~km}$ north of Site 902 . Site 906 was drilled in the thalweg of Berkeley Canyon and penetrated a Miocene submarine canyon that had been subsequently filled. The upper Oligocene to middle Miocene strata beneath the buried middle Miocene Canyon, and the middle to upper Miocene strata beneath modern Berkeley Canyon are relatively undisturbed. The $605-\mathrm{m}$-thick sedimentary sequence recovered is similar to that of other sites and contains middle to upper Eocene biosiliceous chalks and Oligocene to Holocene siliciclastic sediment. Cruise Ew9009 Lines 1027 and 1005 and seismic data collected during Leg 150 were used to interpret the seismic reflectors at Site 906. Because of erosion in the canyon setting, several reflectors documented at other slope sites are missing at Site 906. Seismic reflectors $\mathrm{m} 1, \mathrm{ml} .5$, and $\mathrm{m} 2$ were identified and correlated to Miocene strata at Site 906 (Figs. 2, 3). Two local reflectors, canyon-1 (can1) and canyon-2 (can2), mark a phase of canyon cutting and infilling. Middle Miocene reflector $\mathrm{m} 6$ marks the floor of the canyon, and seismic reflector ol marks the unconformity between the upper Eocene biosiliceous chalks and the upper Oligocene siliciclastics.

The upper continental rise Site 905 was drilled in $2700 \mathrm{~m}$ of water and is located $34.5 \mathrm{~km}$ from the base of the continental slope. Site 905 permitted us to evaluate the age and character of downslope transport deposits to the continental rise. Sediment recovered from the continental rise is $910 \mathrm{~m}$ thick and ranges from the middle Miocene to the lower Pleistocene. Mass-transport and gravity-flow deposits are volumetrically more important in the continental rise than at slope Sites 902-904. The sedimentary sequence is composed of $231 \mathrm{~m}$ of middle Miocene hemipelagic silty clays, $143 \mathrm{~m}$ of upper to middle Miocene sediment dominated by mass-transport deposits, $322 \mathrm{~m}$ of upper Miocene to lower Pleistocene predominantly hemipelagic silty clays, and $215 \mathrm{~m}$ of primarily mass-transport deposits. The seismic character of the upper continental rise is difficult to interpret because of poor borehole correlation and the lack of widely mappable seismic reflectors (Mountain, Miller, Blum, et al., 1994). Seismic reflectors Brown (lower Pleistocene), Blue (erosional unconformity during the middle 


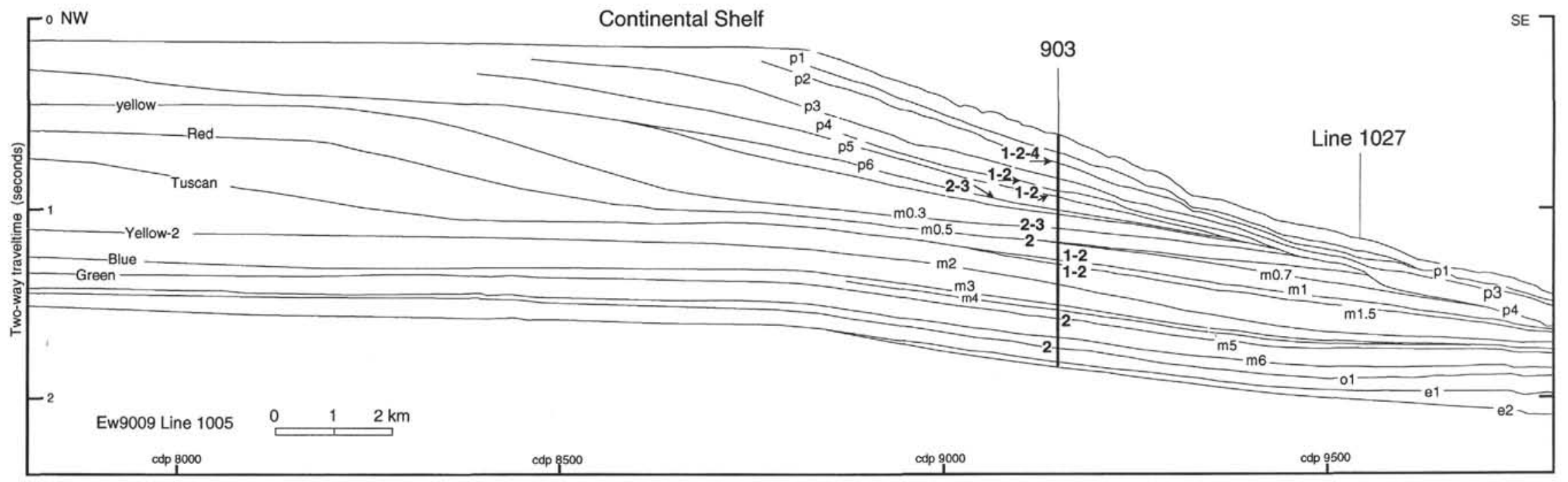

Figure 2. Line-drawing interpretation of dip-oriented MCS profile Ew9009 Line 1005 across the outer continental shelf and slope (Mountain, Miller, Blum, et al., 1994). See Figure IB for location of profile and Table 1 for explanation of seismic reflectors. Bold numbers indicate correlation of facies types described in this paper to seismic reflectors.

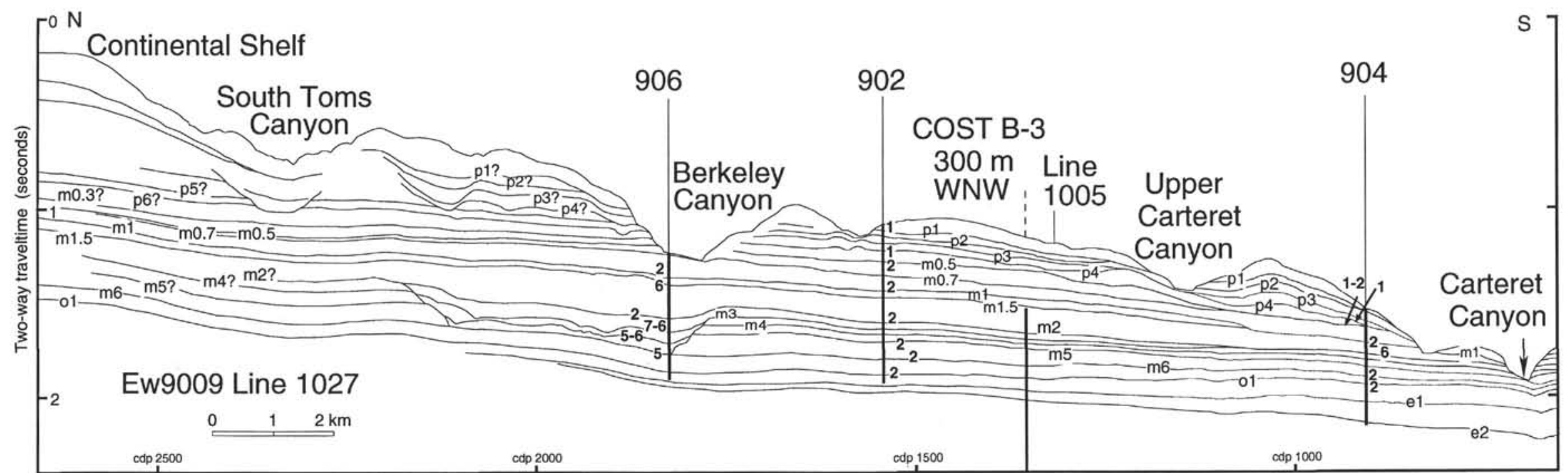

Figure 3. Line-drawing interpretation of strike-oriented MCS profile Ew9009 Line 1027 along the continental slope (Mountain, Miller, Blum, et al., 1994). See Figure 1B for location of profile and Table 1 for explanation of seismic reflectors. Bold numbers indicate correlation of facies types described in this paper to seismic reflectors. 
Table 2. Classification of sediment facies of the mass-transport deposits recovered during Leg $\mathbf{1 5 0 .}$

\begin{tabular}{|c|c|c|}
\hline Facies & Description & Sedimentary process \\
\hline 1 & $\begin{array}{l}\text { Contorted silty clay with clay clasts; matrix and clasts are the same age. Soft-sediment } \\
\text { deformation features include folds, dipping, discordant or truncated beds and layers. Mud } \\
\text { clasts up to } 8 \mathrm{~cm} \text { in diameter, commonly deformed. Sand- to cobble-sized lithic fragments } \\
\text { and clasts. Pleistocene mud clasts chlorite-rich; Miocene mud clasts kaolinite-rich. }\end{array}$ & $\begin{array}{l}\text { Matrix-supported muddy slumps and debris flows } \\
\text { formed an intercanyon slope environment. }\end{array}$ \\
\hline 2 & $\begin{array}{l}\text { Quartz- and glauconite-rich sands. Medium to fine; occur in discrete laminae and beds to }>2 \mathrm{~m} \\
\text { thick or disseminated through silty clay intervals. Beds have sharp bases and rarely normal } \\
\text { grading or Bouma divisions. Quartz predominant in Pleistocene; glauconite predominant in } \\
\text { the Oligocene and lower Miocene. }\end{array}$ & $\begin{array}{l}\text { Turbidity currents, related gravity-controlled flows } \\
\text { and sandy mass-flows. }\end{array}$ \\
\hline 3 & $\begin{array}{l}\text { Sands with lithic and mud clasts; matrix and clasts of variable ages. Matrix is fine to coarse } \\
\text { sand, poorly sorted, ranging from late Miocene to Pleistocene in age. "Floating" lithic clasts } \\
\text { are up to pebble sized; mud clasts are up to } 4 \mathrm{~cm} \text {. Mud clasts range from Paleocene to middle } \\
\text { Pleistocene in age. }\end{array}$ & Sandy debris flow. \\
\hline 4 & $\begin{array}{l}\text { Normally graded sand and mud clasts. Medium-sized quartz sand bed with graded mud clasts } \\
\text { in lower } 1 \mathrm{~m} \text {. Mud clasts are } 0.5-4 \mathrm{~cm} \text { in diameter. Sand above mud clasts contains scattered } \\
\text { quartz granules and shell fragments. }\end{array}$ & $\begin{array}{l}\text { Turbidity current and/or debris flow (has affinities of } \\
\text { both types of flow). }\end{array}$ \\
\hline 5 & $\begin{array}{l}\text { Clast-supported and matrix-supported conglomerates and breccias. Matrix is silty clay; mud } \\
\text { clasts are angular to subrounded and }<1 \text { to }>25 \mathrm{~cm} \text { in diameter. Soft-sediment deformation } \\
\text { includes folds, flow structures, clastic injections, and deformed clasts. Brittle deformation } \\
\text { includes microfaults, which often bound clasts, and extensive fracturing of clasts. }\end{array}$ & $\begin{array}{l}\text { Slumps in a canyon setting. Apparent clasts contained } \\
\text { within larger clasts suggest two or more cycles of } \\
\text { mass-wasting events. }\end{array}$ \\
\hline 6 & $\begin{array}{l}\text { Interbedded sands, silts, and silty clays with thin intervals of soft-sediment deformation. } \\
\text { Laminae and thin beds }(1-5 \mathrm{~cm}) \text { of fine sands and silty clays, which form a thinning-upward } \\
\text { and fining-upward cycle. Rare thin intervals of soft-sediment deformation with folds, } \\
\text { discordant laminae, and mud clasts. }\end{array}$ & $\begin{array}{l}\text { Turbidity currents and related gravity-controlled } \\
\text { flows; intervals of soft-sediment deformation are } \\
\text { localized slumps and debris flows. }\end{array}$ \\
\hline 7 & Laminated silty clays containing laminae of diagenetic siderite. & $\begin{array}{l}\text { Hemipelagic to pelagic deposition; siderite of } \\
\text { diagenetic origin. }\end{array}$ \\
\hline $8 \mathrm{a}$ & $\begin{array}{l}\text { Deformed silty clay with clay and lithic clasts; matrix and clasts are of variable ages. Matrix } \\
\text { rarely deformed or contorted. Mud clasts have diverse ages, are }<1 \text { to }>50 \mathrm{~cm} \text { in diameter and } \\
\text { are subrounded. Lithic clasts are rarely up to } 6 \mathrm{~cm} \text { in diameter. Pebble-sized shells and } \\
\text { bioclasts common. Glauconitic sands near base. }\end{array}$ & $\begin{array}{l}\text { Muddy debris flows. Sediments show both terrestrial } \\
\text { and marine sources and form fill in modern } \\
\text { Berkeley submarine canyon. }\end{array}$ \\
\hline $8 \mathrm{~b}$ & $\begin{array}{l}\text { Contorted silty clays with chalk, clay, and lithic clasts; matrix and clasts are of variable ages. } \\
\text { Contorted, discordant dipping beds and folds. White Eocene carbonate clasts commonly } \\
\text { deformed. Mud clasts are }<1 \text { to }>10 \mathrm{~cm} \text { in diameter. Lithic clasts are sand to pebble sized. } \\
\text { Clasts range from Eocene to Pleistocene in age. }\end{array}$ & $\begin{array}{l}\text { Muddy slumps and debris flows. One or more } \\
\text { episodes of transport. }\end{array}$ \\
\hline 9 & $\begin{array}{l}\text { Clast-supported conglomerate; clasts are of variable ages. Semi-indurated angular to } \\
\text { subrounded mud clasts of variegated color and lithologies from }<1 \text { to } .50 \mathrm{~cm} \text { in diameter, } \\
\text { which are commonly bounded by steeply dipping microfaults. }\end{array}$ & $\begin{array}{l}\text { Slumps and debris flows (possibly a transitional phase } \\
\text { from one to the other). Some clasts appear to } \\
\text { represent deformed matrix material that contains } \\
\text { smaller clasts and suggests two or more cycles of } \\
\text { mass-wasting events. }\end{array}$ \\
\hline
\end{tabular}

Pliocene), Merlin (late middle Miocene hiatus), and Yellow (middle Miocene) were interpreted by Mountain, Miller, Blum, et al. (1994) from USGS Line 25, BGR Line 201, Leg 150 Line 1, and from previous studies of the continental rise by Mountain and Tucholke (1985).

\section{FACIES CLASSIFICATION AND DESCRIPTION}

Nine sedimentary facies are recognized in the Leg 150 cores (Table 2) based on the styles of soft-sediment deformation, mineralogy of sediments, and biostratigraphic age of the deposits. Facies 1 to 4 are predominantly found on the slope, Facies 5 to $8 \mathrm{a}$ are characteristic of a slope canyon, and Facies $8 \mathrm{~b}$ and 9 occur on the continental rise.

\section{Facies 1: Contorted Silty Clay with Intervals of Clay Clasts of the Same Age as the Surrounding Matrix}

Facies 1 is characterized by deformed and contorted silty clay with intervals containing subrounded mud clasts (Fig. 4). A defining characteristic of Facies 1 is that these mud clasts are of the same age as their surrounding matrix. The ages of the clasts were determined from calcareous nannofossil biostratigraphy. Facies 1 occurs at Site 902 (12-22 mbsf, 44-47 mbsf, 98-106 mbsf, 110-122 mbsf), Site 903 (119-121 mbsf, 125-142 mbsf, 209-210 mbsf, 221-231 mbsf, 241-244 mbsf, 246-247 mbsf, 269-274 mbsf, 602-604.5 mbsf, 622-624.5 mbsf, 731-733 mbsf), Site 904 (95-98 mbsf, 104-106 mbsf), and Site 905 (41-72 mbsf, 554-573 mbsf, 618-623 mbsf). The matrix of Facies 1 deposits is primarily composed of silty clays, although sandy silts are also common. The clays of Facies 1 have variegated colors ranging from brownish gray to greenish gray. The greenish colors predominate in the Pleistocene-age clays, whereas the brownish colors are common in the Miocene-age clays. Thin, deformed silt and fine-sand laminae and thin beds are rarely present. Soft-sediment deformation features are common in the matrix of Facies 1 and include (1) recumbent, chevron, and isoclinal folds, (2) low- to high-angle dipping beds and laminae with various orientations, and (3) discordant or truncated beds. Quartz, glauconite, mica, shells, and wood fragments constitute the coarse-grained components that are randomly disseminated throughout the matrix and have, in some instances, been incorporated into the clasts. The organic and inorganic components range from sand- to granule-sized.

Mud clasts are rare in the Pleistocene, but where present are commonly are subrounded with elliptical to elongated shapes. These clasts commonly exhibit flowage or deformation, and clast boundaries are generally not well defined. In contrast, mud clasts in the Miocene section are more indurated, less deformed, and exhibit welldefined boundaries (Fig. 5). Clasts range in size from 2 to $8 \mathrm{~cm}$. The Miocene sediments also differ from the Pleistocene sediments in that they contain an abundance of coarse-grained components including sand- to cobble-sized lithic fragments and clasts. Soft-sediment deformation features are not as prevalent as in the Pleistocene section.

Kaolinite and chlorite are diagnostic of Facies 1. Kaolinite is dominant in the matrix and the clasts of the Miocene sediments, but is generally absent in the Pleistocene sediments (Fig. 6). Analyses of untransported hemipelagic clays from Sites 902 and 906 reveal that kaolinite is also the dominant clay in Oligocene sediment (Fig. 7). In 
A

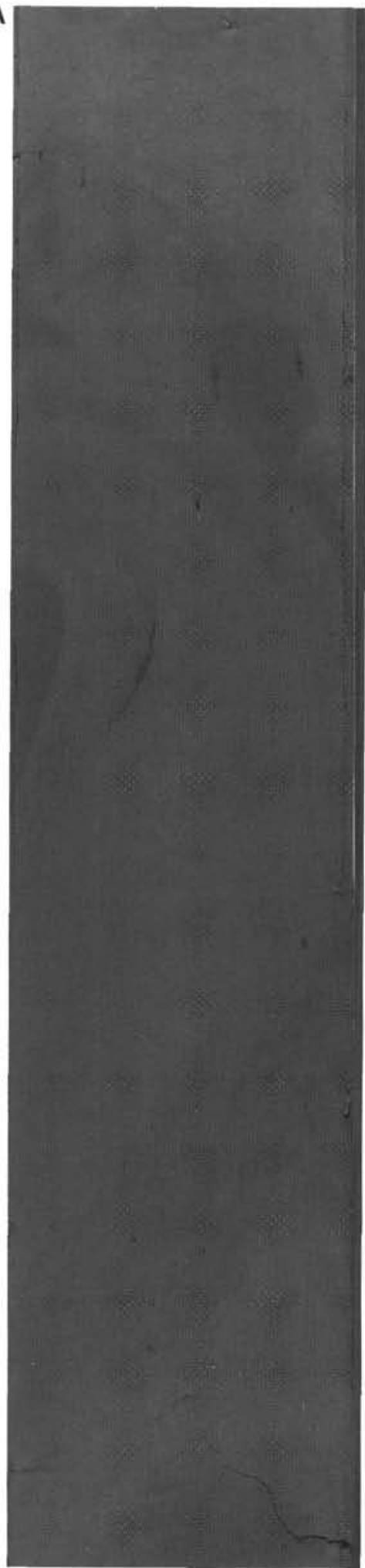

B

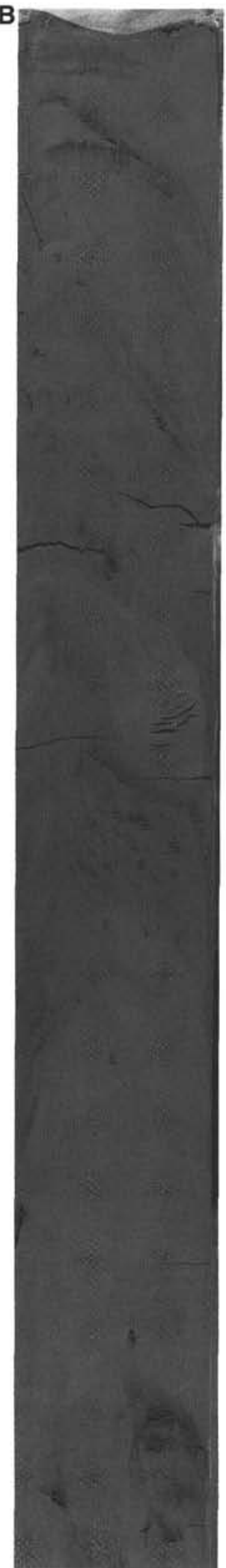

C

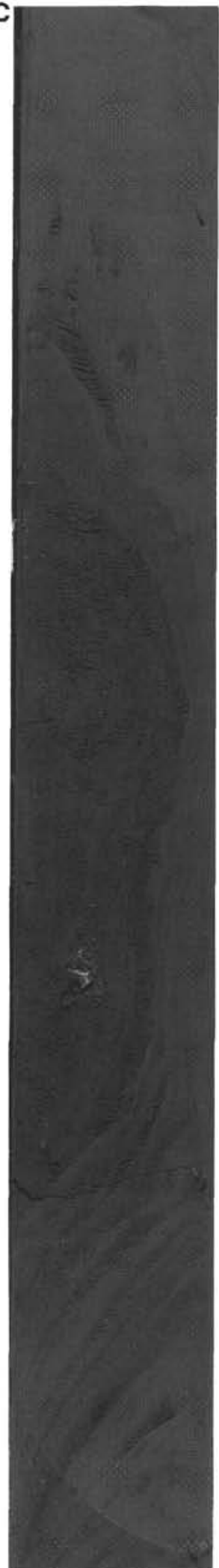

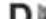

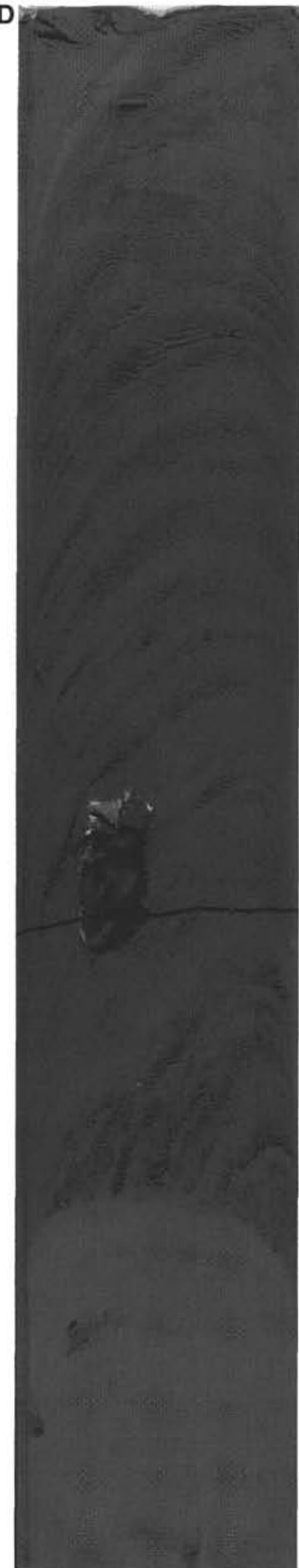

Figure 4. Examples of Facies 1: Pleistocene-age contorted silty clays with clay clasts. A. Soft-sediment deformation features with folds and flowage plus deformed clasts with elongated to elliptical shapes (Interval 150-902D-2H-3, 50-80 cm). B. Matrix with isoclinal folds and rare subrounded mud clasts; clast boundaries are commonly not well defined (Interval 150-902A-2H-4, 0-50 cm). C. Contorted sandy-clay matrix with steeply dipping and folded sand laminae (Interval 150-902A-2H-4, 100-150 cm). D. Gently to steeply dipping sand laminae truncated by an 8-cm-long clay clast. A 3-cm-diameter shell fragment also occurs in Interval $150-902 \mathrm{~A}-2 \mathrm{H}-5,0-35 \mathrm{~cm}$. 
A

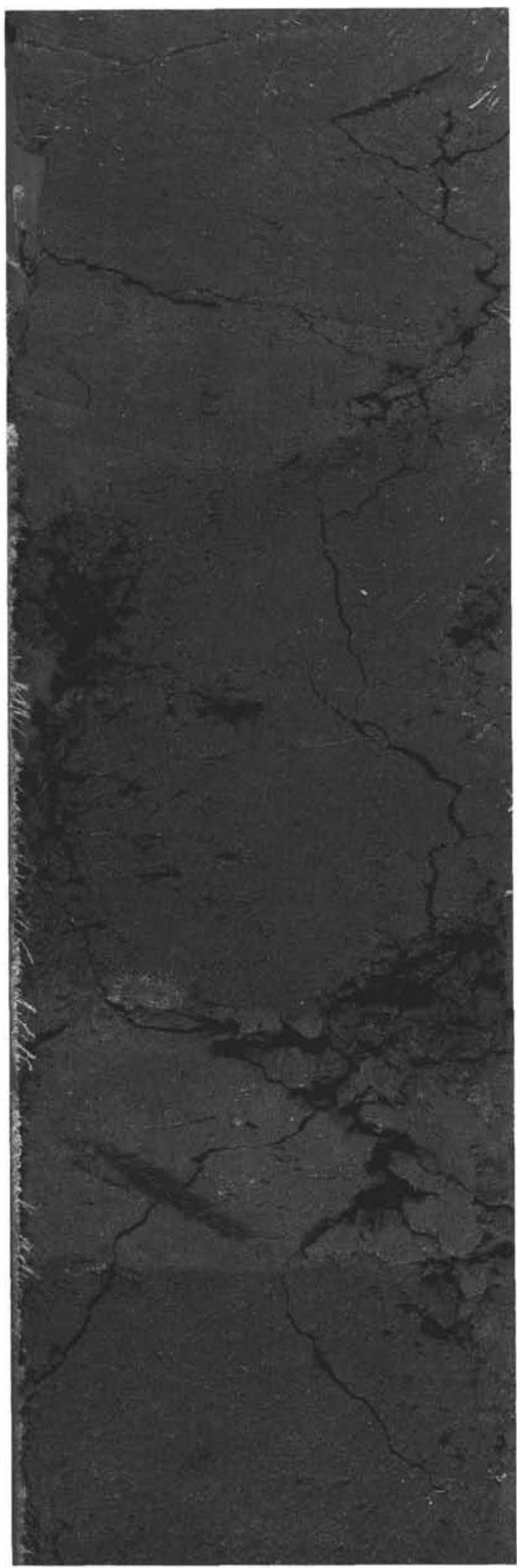

B

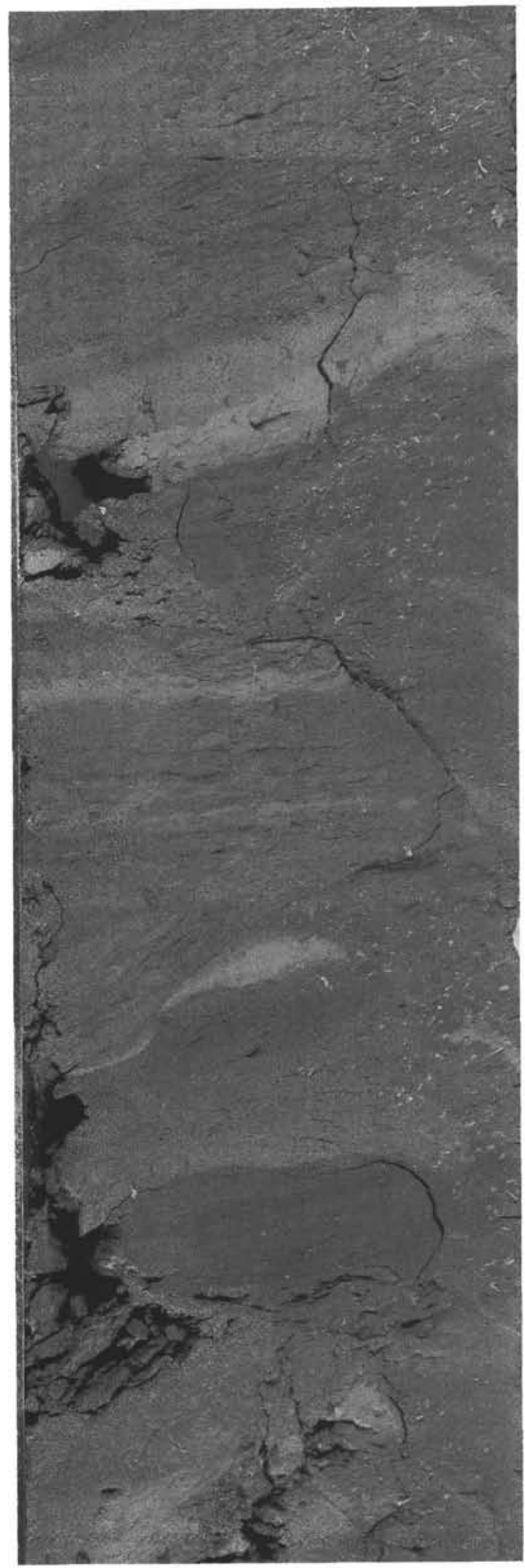

Figure 5. Examples of Facies 1: Miocene mass-transport deposits. A. Clasts exhibiting well-defined boundaries (Interval 150-903C-11R-1, 32-52 cm). B. Clasts of various sizes but of similar age and lithology, also with gently dipping beds (Interval 150-903C-16R-4, 50-70 cm). C. Contorted sandy-silty clay. Such soft-sediment deformation features are not common in Miocene deposits (Interval 150-903A-32X-1, 0-30 cm). 
C

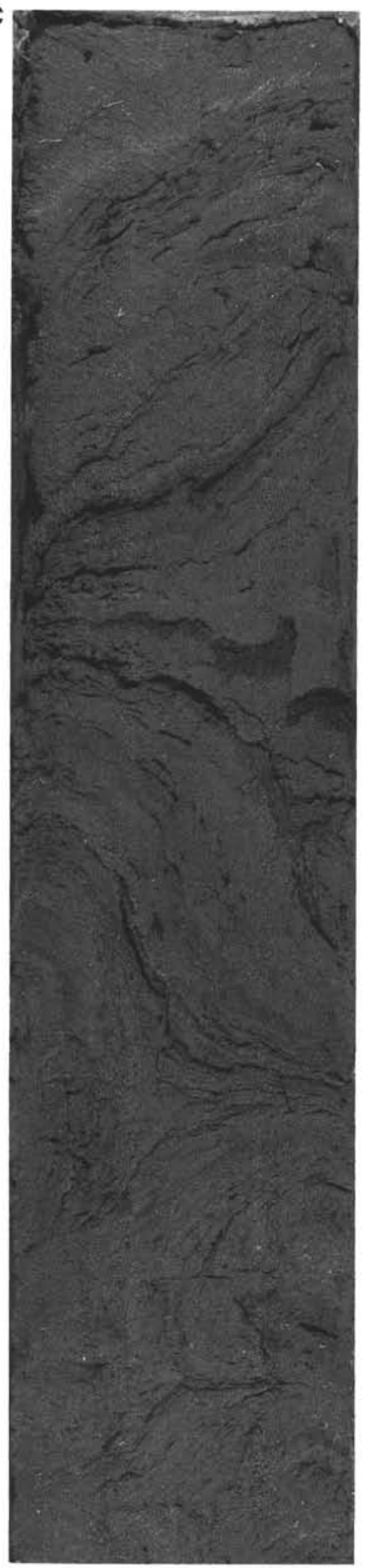

Figure 5 (continued). contrast, chlorite is abundant in the matrix and clasts of all Pleistocene sediment, where kaolinite is generally not present. Analyses of untransported hemipelagic clays from Sites 902 and 906 also reveal that chlorite is the dominant clay in Pleistocene and Pliocene sediments. Illite occurs in clasts of all ages with relative abundances that range up to $100 \%$.

The carbonate content of the clasts and the matrix is also used to identify Facies 1 because distinctive differences in the total carbonate content are observed for the Miocene and Pleistocene mud clasts (Fig. 6 ). The total carbonate content of middle Miocene-age clasts ranges from $2 \%$ to $5 \%$, whereas the upper Miocene clasts contain $<0.25 \%$ total carbonate. In contrast, the Pleistocene-age clasts contain from 5\% to $20 \%$ carbonate. Analyses of pelagic and hemipelagic (untransported) sediment reveal the same pattern as the clast and matrix of Facies 1 mass-transport deposits (Fig. 7) and are also in agreement with shipboard studies. The total carbonate content ranges from $10 \%$ to $30 \%$ in upper Oligocene-age to the lower Miocene-age sediments, but only $5 \%$ to $<0.25 \%$ in the middle to the upper Miocene-age sediments. In contrast, the Pleistocene-age sediments range from $5 \%$ to $20 \%$. Because of the lack of calcareous microfossils, clasts in middle to upper Miocene mass-transport deposits could not be dated and are classified as "barren." However, because clay composition is apparently such a reliable indicator of the age during which the sediment was deposited, and because middle to upper Miocene sediment recovered from all sites lack calcareous microfossils for dating, these barren clasts that contain kaolinite are presumably middle to upper Miocene in age.

\section{Interpretation}

Intervals of Facies 1 that show soft-sediment deformation features, such as contorted or folded beds, are interpreted as slumps. The less-deformed intervals of Facies 1 that contain abundant mud clasts are interpreted as muddy debris flows. The slumps of Facies 1 were apparently initiated while the sediment was soft, leading to extensive mixing, remolding, and partial destruction of initial depositional structures. At this stage the plastic deformation of layers could lead to the formation of mud clasts suspended in a muddy matrix and transformation into debris flows. Failure of slightly more indurated sediment may have initiated the Miocene slumps, some of which were transformed into debris flows containing angular clasts. In summary, the Pleistocene sediments of Facies 1 are mainly muddy slumps, whereas the Miocene sediments are mainly muddy debris flows.

These age and lithologic characteristics of the slumps and debris flows (i.e., matrix and enclosed clasts of equivalent age and similar clay mineralogy and carbonate content) indicate that these deposits represent failures from localized sources, which did not entrain allochthonous material during their transport and deposition. Detachment of sediment from the upper slope is a possible source for the Pleistocene slumps. Such localized slope detachments are a common type of failure observed in the Quaternary sediments seaward of New Jersey and Delaware (McGregor and Bennett, 1977, 1979, 1981; Malahoff et al., 1980; Farre and Ryan, 1987). Similar localized upper slope failures and detachments were also probably the source for the Miocene debris flows of Facies 1. The position of the paleoshelf edge during the Miocene was apparently beneath the modern middle shelf shoreward of the modern shelf break (e.g., Fig. 2). Gradients were probably much gentler than those of the modern slope. Miocene muddy debris flows were possibly transported for greater distances along gentler slopes than during the Pleistocene.

Kaolinite, chlorite, and illite are considered of detrital origin in marine sediment (Biscaye, 1965; Griffin et al., 1968; Singer, 1984). Chlorite in marine sediment is associated with mechanical weathering and glacial erosion of high-latitude climatic conditions. In contrast, kaolinite is associated with intense leaching and chemical weathering and is common today in the tropics. The occurrence of chlorite in the Pleistocene sediment offshore New Jersey reflects the change to the colder climatic conditions that prevailed in the northern 


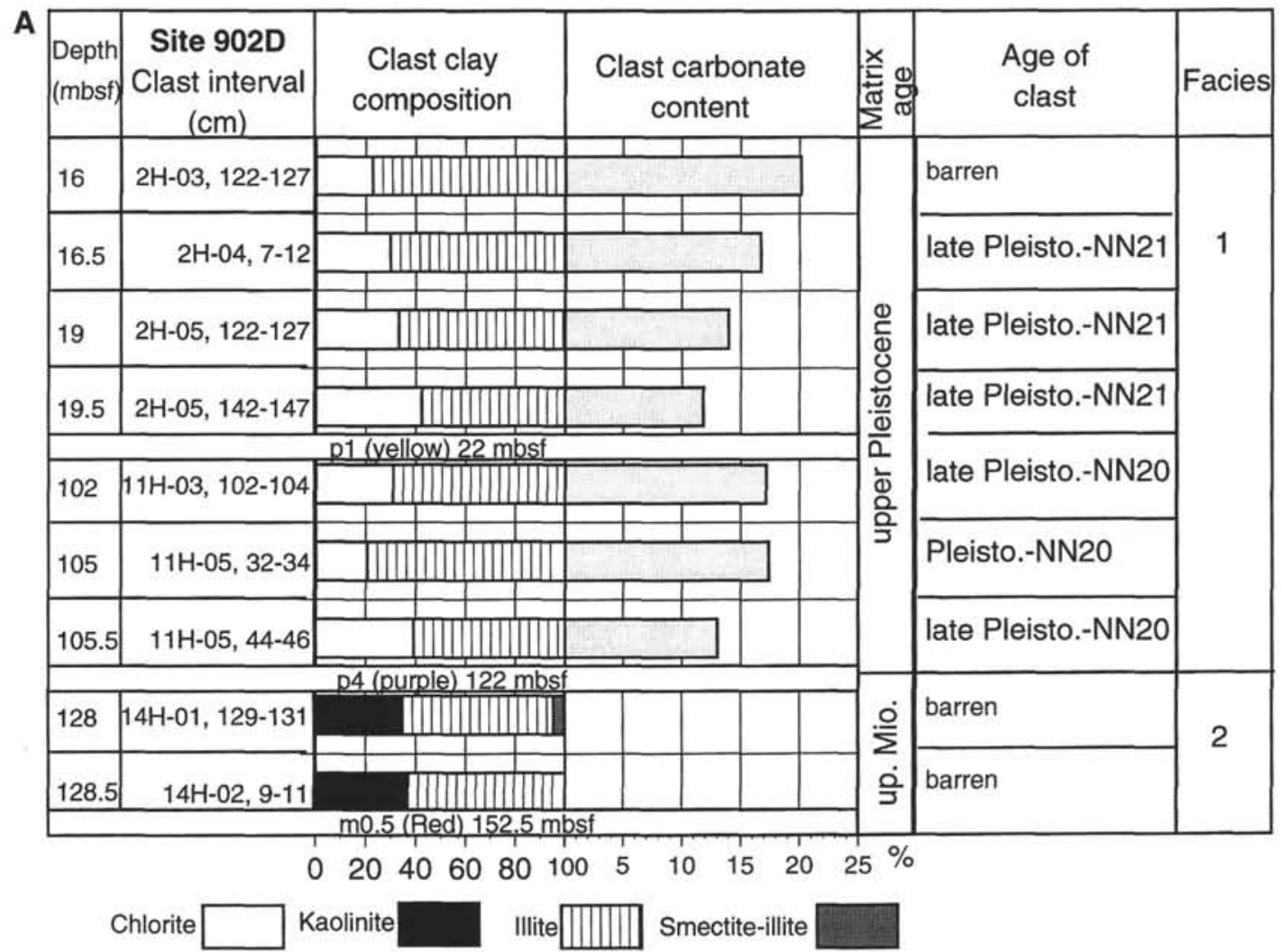

Figure 6. Analyses of clasts from mass-transport deposits in all slope sites showing (1) depth of sample in meters below the seafloor (mbsf), (2) clast interval (cm), (3) clast clay mineralogy, (4) clast carbonate content, (5) age of matrix, (6) age of clast, and (7) facies type. A. Hole 902D. B. Holes 903A, 903C, and 903D. C. Hole 904A. D. Site 906.

latitudes during the Pleistocene. The presence of kaolinite in Miocene and Oligocene sediments indicates weathering and erosion of continental sources. Illite in marine sediment is associated with river and eolian input. The fluctuations of carbonate content observed for the sediment may have resulted from very high organic carbon accumulation rates that occurred from the middle to the upper Miocene (Mountain, Miller, Blum, et al., 1994). It is likely that these events lowered the pore water $\mathrm{pH}$ that led to the dissolution of calcareous microfossils. A very high influx of terrestrial plant matter occurred from the middle to the upper Miocene and may be the source for the organic carbon.

\section{Facies 2: Quartz- and Glauconite-Rich Sands}

Medium- to fine-grained quartz- and glauconite-rich sands constitute Facies 2. These sands occur as discrete laminae and beds up to 8 $\mathrm{m}$ thick (on the continental rise), or as disseminated sands throughout some intervals of silty clays and clayey silts (Fig. 8). Facies 2 occurs at Site 902 (132-135 mbsf, 151-152.5 mbsf, 250-256 mbsf, 260262 mbsf, 278-290 mbsf, 394.6-395 mbsf, 402-404 mbsf, 453-465 mbsf, 511-512 mbsf, 52-523 mbsf, 564-568 mbsf, 609-612 mbsf, 680-681 mbsf), at Site 903 (119-121 mbsf, 125-142 mbsf, 209-210 mbsf, 221-231 mbsf, 241-244 mbsf, 246-247 mbsf, 269-274 mbsf, 298-307 mbsf, 326-327 mbsf, 337-359 mbsf, 369-392 mbsf, 403404 mbsf, 421-422 mbsf, 424-429 mbsf, 440-459 mbsf, 487-493 mbsf, 500-520 mbsf, 578-581 mbsf, 602-604.5 mbsf, 622-624.5 mbsf, 731-733 mbsf, 977-978 mbsf, 1060-1064 mbsf), at Site 904 (71-74 mbsf, 104-106 mbsf, 136-139 mbsf, 164-168 mbsf, 179180 mbsf, 225-221 mbsf, 225-231 mbsf, 240-272 mbsf, 279-341 mbsf), at Site 905 (41.5-48 mbsf, 72-80 mbsf, 165-170 mbsf), and at Site 906 (112-115 mbsf, 278.5-279 mbsf). Facies 2 sands rarely occur in the Pleistocene sections, but are common in the late middle to upper Miocene sections. Where present, the sands constitute up to $80 \%$ of the sediment. Most sand beds exhibit sharp bases, but normal grading or complete Bouma sequences are rarely observed. Quartz is predominant in the Pleistocene, whereas glauconite is predominant in the Oligocene and lower Miocene. Both quartz- and glauconite-rich sands occur in the upper Miocene. The glauconitic sands are generally very bioturbated (Fig. 9).

Sand- to pebble-sized quartz, mica, pyrite, lithic, shell, and wood fragments are common in Facies 2. The occurrence of feldspar, traces of amphibole, and carbonate (calcite and dolomite) corresponds to influxes of quartz and glauconite sands and suggests that the carbonates in these instances are detrital. This trend is quite evident in the Pleistocene sections. Calcite is rare to absent in sediments of middle to upper Miocene Facies 2 and carbonates are primarily diagenetic siderite and minor gypsum. Terrestrial plant material is abundant and composes up to $8 \%$ of the total sediment in the middle to upper Miocene sands of Facies 2 at the upper slope Sites 902, 903, and canyon Site 906. This material may be the source of the organic carbon that contributed to the dissolution of carbonates. Terrestrial plant matter also occurs, to a lesser extent, disseminated in the silty clays. Facies 2 sandy silts and silty sands rich in glauconite occur in the late Oligocene section just above the unconformity at the top of the late Eocene, and in the early Miocene section near the unconformity that separates the late Oligocene from the early Miocene at Sites 902, 903, and 904 (Fig. 10). 
B

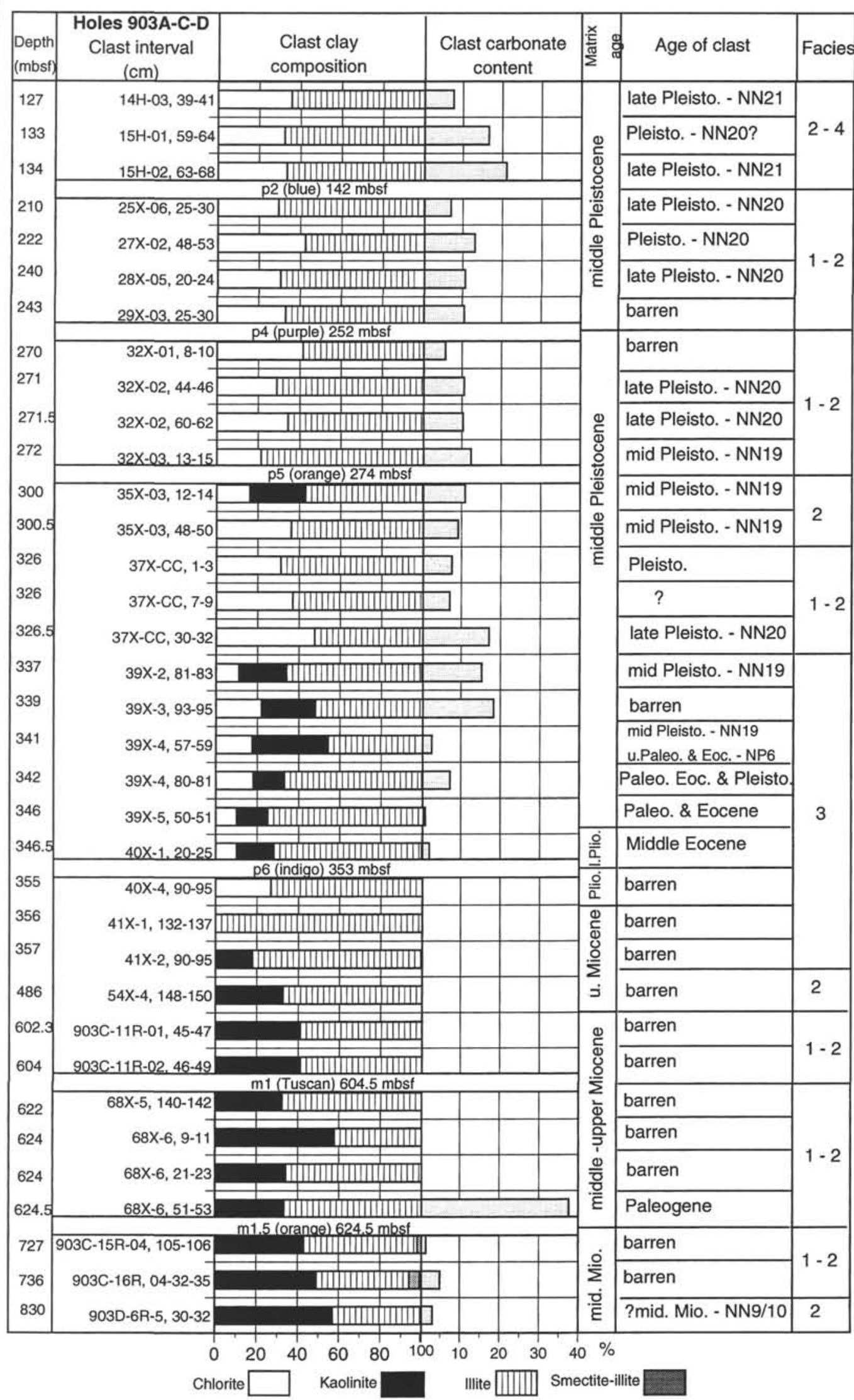

Figure 6 (continued). 


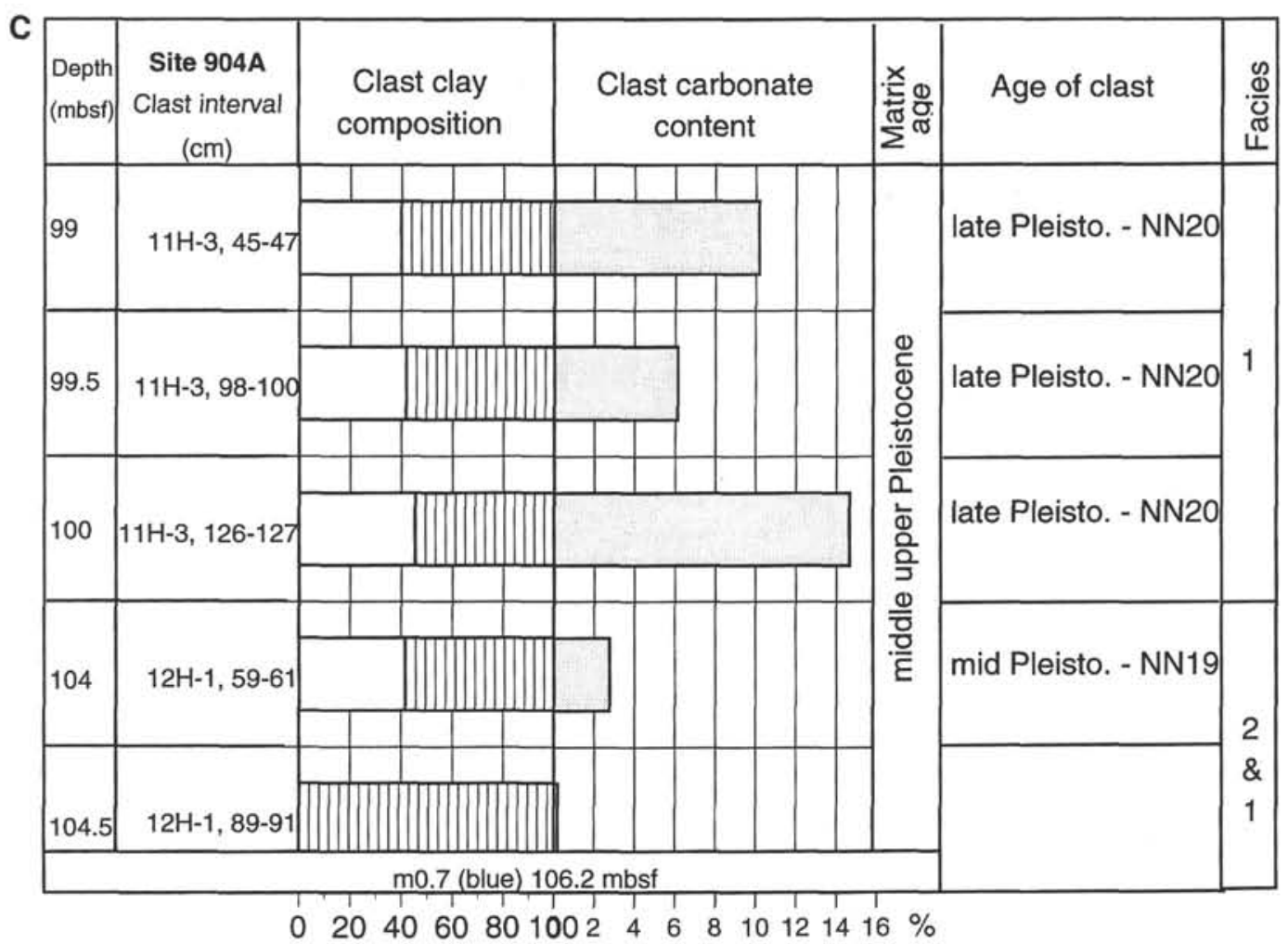

Chlorite $\square \quad$ Illite $\amalg$

Figure 6 (continued).

\section{Interpretation}

The sandy deposits of Facies 2 appear to have been deposited predominantly by turbidity currents and related gravity-controlled flows, and by mass flows. Disseminated sands could have been deposited by sand-rich flows supported by a clay matrix in which the flow rheology was plastic rather than fluidal. The association between mass flows and sands is evident (Figs. 4C, D, E; 5D; 8A, C.) in the sedimentary deposits in which sands of Facies 2 occur with mass flows of Facies 1. However, disseminated sands of Facies 2 are not always associated with deformation features, and in these cases the deposition of sands as a result of mass flows is not well established (Figs. 9A, B; 10A, B). The sand beds could have been deposited by low-density turbidity currents (Fig. 8B).

The occurrence of quartz, mica, feldspar, amphibole, and wood fragments indicates a terrestrial source, such as a river, whereas the presence of shells and glauconite suggests a shallow-marine origin, possibly the shelf (Griffin et al., 1968; Odin and Matter, 1981). The increase of Facies 2 in the deeper marine environment of the late middle to upper Miocene is consistent with the progradation of shallowwater facies.

\section{Facies 3: Sands with Lithic and Mud Clasts of Variable Ages}

Facies 3 is composed of fine- to coarse-grained sands that contain mud and lithic clasts. This facies is observed in only one 20 -m-thick interval in Hole 903A (338-358 mbsf) on the upper slope. The sands are poorly sorted, gray to brown in color and contain quartz, chert, mica, glauconite, shells, and wood fragments (Fig. 11). Inorganic and organic clasts range from coarse sand- to pebble-sized. Clay clasts are brown, green, and rust in color and up to $4 \mathrm{~cm}$ in diameter. The sand matrix of this interval shows variable ages including late Mio- cene ( $7 \mathrm{~m}$ thick), Pliocene ( $2.5 \mathrm{~m}$ thick), late Pliocene ( $\sim 4 \mathrm{~m}$ thick), and middle Pleistocene (5.5 m thick). One significant aspect is that the matrix of the upper $10 \mathrm{~m}$ of this interval is late Pliocene and middle Pleistocene in age, whereas the clasts within this matrix range in age from Paleocene to middle Pleistocene.

Both kaolinite and chlorite are contained within individual clasts and the carbonate content of the clasts varies from $<0.25 \%$ to $20 \%$. The occurrence of both these clays together (kaolinite characteristic of the Miocene and chlorite of the Pleistocene and Pliocene) is consistent with the occurrence of clasts of diverse ages (see Fig. 7 and discussion above). The clay clasts contain sand and granules near their rims, suggesting mixing with the sandy matrix. The lithic pebbles and clasts are randomly scattered ("floating") throughout the sands. The lower $9 \mathrm{~m}$ of this unit is composed of glauconitic sands, which constitute up to $80 \%$ of this interval. Quartz granules are also present. Four diagenetic calcite-cemented intervals up to $10 \mathrm{~cm}$ thick occur within the glauconitic sands. The content of terrestrial plant material is $16 \%$, which is higher than in any other interval at Sites 902 and 903 (up to 8\%) (Mountain, Miller, Blum, et al., 1994).

\section{Interpretation}

Facies 3 is interpreted as a sandy mass flow such as a debris flow. This interpretation is supported by the suspended or "floating" clay and lithic clasts in the sandy matrix which indicate plastic flow. The fact that Paleocene- to Pleistocene-age clasts have been incorporated into the Pleistocene matrix indicates deep erosion. Paleocene clasts have not been found anywhere else in the slope or rise mass-wasting deposits, and Paleocene strata are deeply buried beneath the shelf (Poag, Watts, et al., 1987). In contrast, deep erosion into the coastal plain has exposed Paleocene, Eocene, and Miocene deposits (Pazzaglia, 1993). Cretaceous through Eocene fluvial and marine deposits 
D

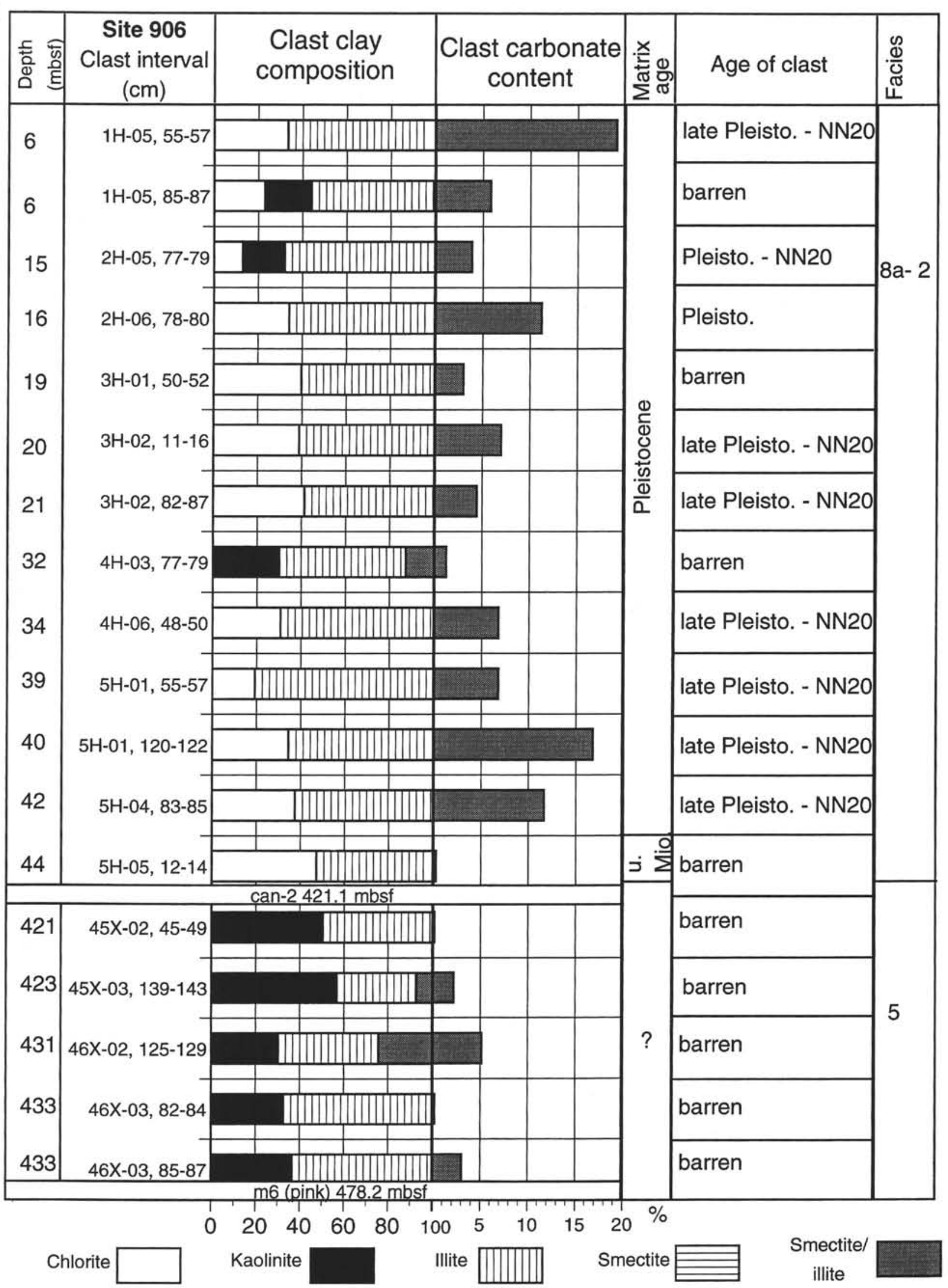

Figure 6 (continued). 

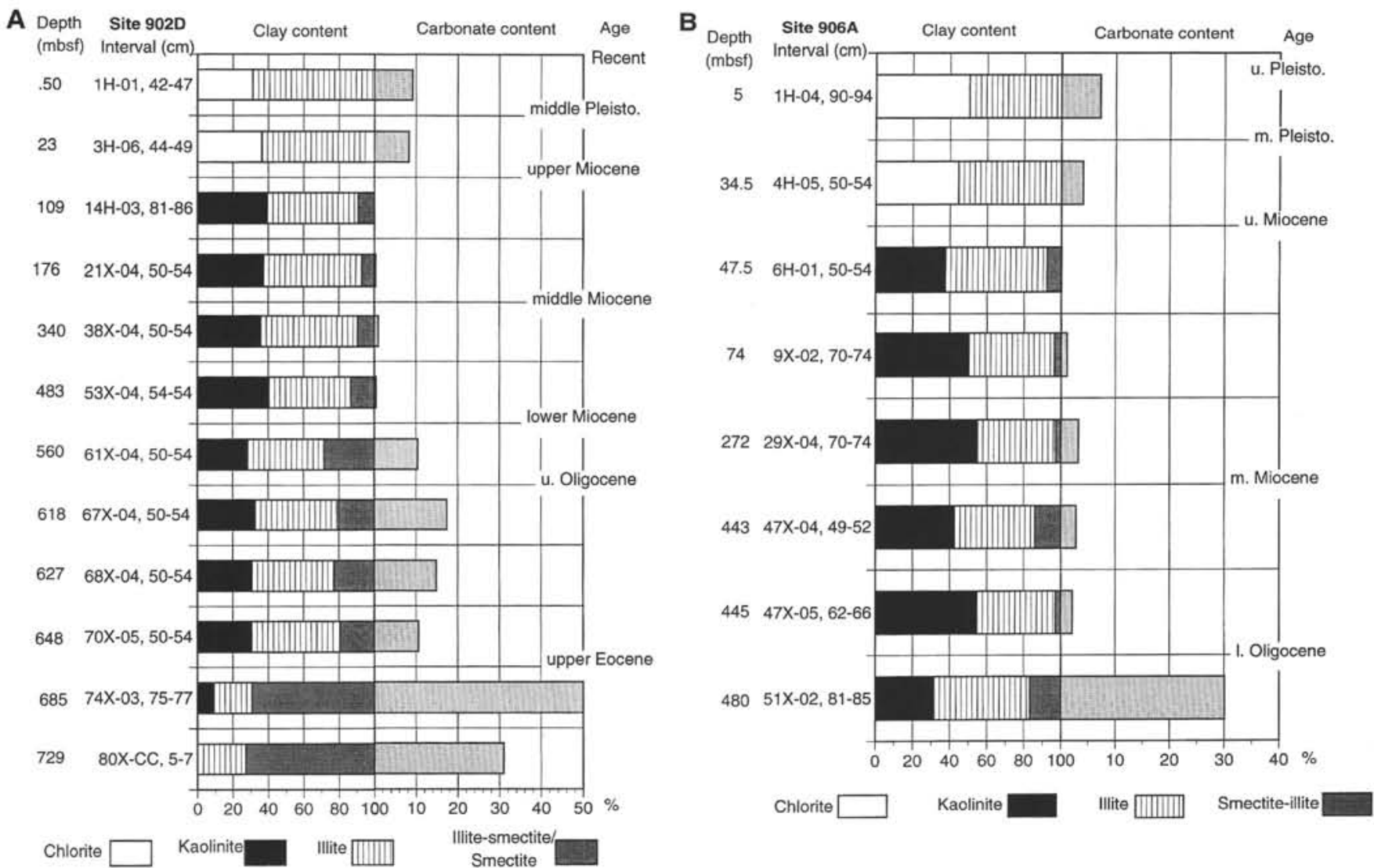

Figure 7. Comparison of in situ lithology vs. age. Note abrupt changes in the composition of the clays from the Miocene to the Pleistocene, as well as the large variations in carbonate content from late Eocene to Holocene. A. Hole 902D. B. Hole 906A.

dip basinward along the middle Atlantic Coastal Plain and fluvial terraces and alluvial sheets of late Miocene to Pleistocene age unconformably overlie these deposits (Pazzaglia, 1993). A possible source for Facies 3 deposits is the coastal plain, where the Paleocene and Eocene are exposed. Mass flows are known to travel hundreds of kilometers down slopes of less than $1^{\circ}$ (Embley and Jacobi, 1977; Damuth and Embley, 1981). Alternatively, deep erosion and/or canyon cutting into the continental shelf or upper slope could have exposed the Paleocene and Eocene. The high content of terrestrial plant material in Facies 3 strongly suggests a terrestrial source, possibly a river.

\section{Facies 4: Normally Graded Sand and Mud Clasts}

Facies 4 occurs only in one unusual 2.8 -m-thick interval in Hole $903 \mathrm{~B}$ on the upper slope (Sections 150-903B-16H-6 and 7; 144.5$142 \mathrm{mbsf}$ ). This bed consists of normally graded medium-sized, wellsorted quartz sand that contains subrounded to well-rounded reddish gray mud clasts in the lower meter (Fig. 12). These mud clasts are also normally graded and range from $5 \mathrm{~mm}$ to $4 \mathrm{~cm}$ in diameter (Fig. $12 \mathrm{~A}, \mathrm{~B}, \mathrm{C})$. The overlying sands are gray in color and rarely contain scattered quartz granules, shell fragments, and mica (Fig. 12D). Incomplete recovery above the unit suggests that perhaps the sand bed was much thicker. The age of the matrix is middle Pleistocene and the clasts are "barren."

\section{Interpretation}

Facies 4 has characteristics of both a turbidity-current deposit and debris-flow deposit. The generally medium sand of the upper part of the deposit has "floating" coarse sand and granules, which suggests plastic mass flow, whereas the lower portion contains normally graded mud clasts that suggest a fluidal turbidity flow. Clearly the transporting medium had to be viscous enough to suspend the clasts; how- ever, the medium also had to be fluid enough to allow the clast to settle by gravity. In the depositional sequence proposed by Hampton (1972), the transition between a debris flow and a turbidity current involves extensive dilution of the debris-flow material and a decrease in the density from $2.0 \mathrm{~g} / \mathrm{cm}$ to $1.1 \mathrm{~g} / \mathrm{cm}$. The clasts of Facies 4 were probably formed as part of a debris flow and were deposited during the transition from debris flow to turbidity current. The dilution of the sands in this case had to be sufficient to allow for the gravitational settling of the clasts.

\section{Facies 5: Clast-and Matrix-Supported Conglomerate and Breccia}

Facies 5 occurs only in one $~ 60$-m-thick interval at Site 906 (from 478 to $421 \mathrm{mbsf}$ ) in a canyon on the slope. This facies is characterized by the occurrence of intervals of clast- and matrix-supported conglomerates and breccias that range in thickness from $\sim 1 \mathrm{~m}$ to $6 \mathrm{~m}$ and are bounded by sharp, angular-dipping contacts (Fig. 13). Intervals of dark olive brown silty clays separate conglomerates and breccias. The matrix of the breccias and conglomerates is olive gray silty clay. The breccias and conglomerates have both matrix- and clast-supported intervals. Soft-sediment deformation features with isoclinal folds, flow structures, and deformed clasts are common in the olive-gray silty-clay matrix. Other sections show more brittle deformation including microfaults and extensive fracturing of the clasts. Zones of injected silty clay with smaller-sized clasts also occur. The mud clasts in this matrix are angular to subrounded and range from $<1 \mathrm{~cm}$ to $25 \mathrm{~cm}$ in diameter, although some could be much larger. The clasts are often bounded by angular, dipping microfaults and are commonly dark olive brown in color; however, shades of grays to olive browns also occur. Kaolinite is the dominant clay in the clasts, and carbonate content ranges from $<0.25 \%$ to $5 \%$. This suggests that the age of the clasts is middle to upper Miocene. 


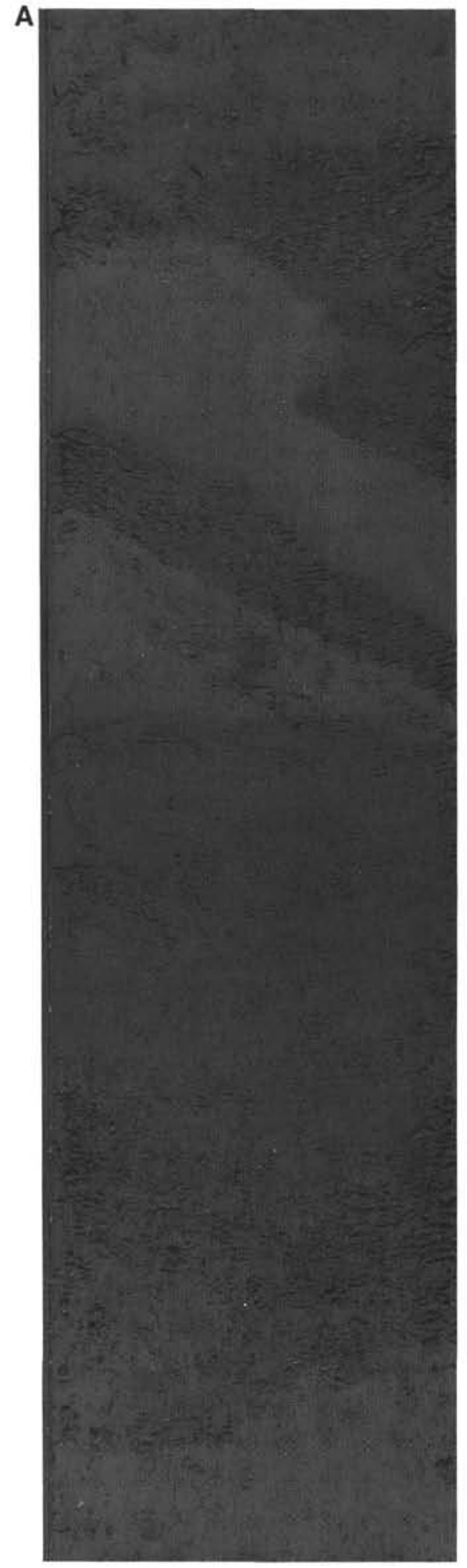

B

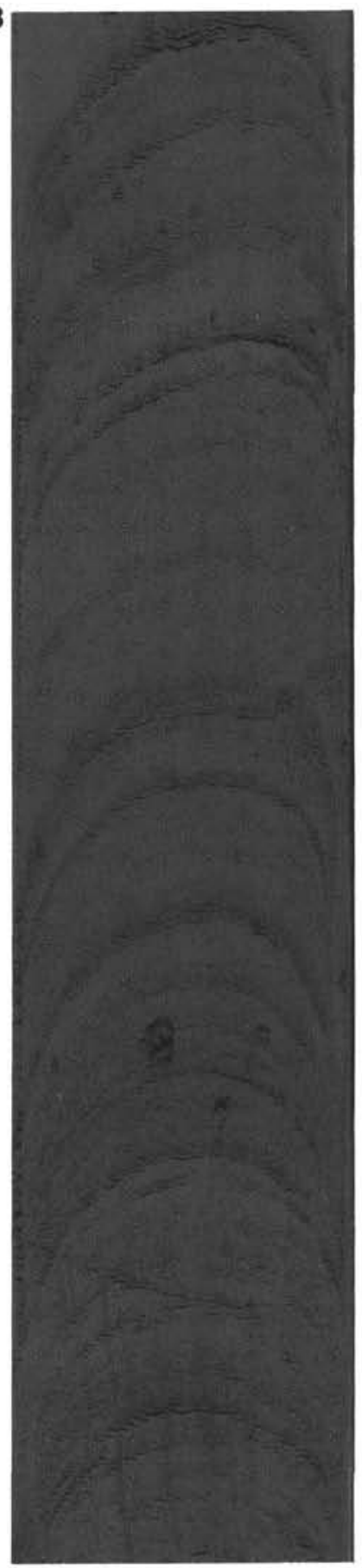

C

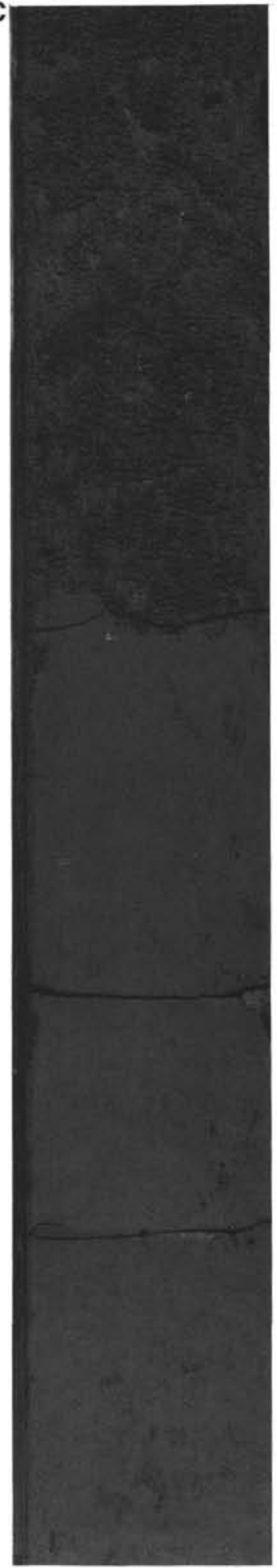

Figure 8. Examples of Facies 2: disseminated sands and sand beds. A. Disseminated quartz sands in Pleistocene mass-transport deposit (Interval 150-902D-9H3, 80-105 cm). B. Pleistocene sand laminae (Interval 150-902B-1H-6, 65-95 cm). C. Disseminated glauconitic sands (Interval 150-904A-12H-2, 50-90 cm). 


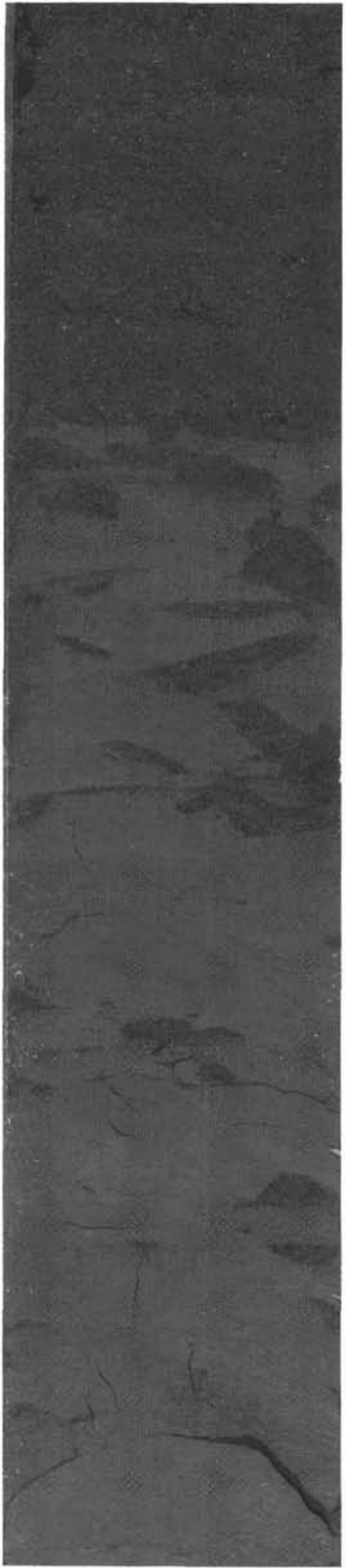

Figure 9. Examples of Facies 2: Miocene glauconitic sands are extensively burrowed (Interval 150-903A-64X-4, 65-95 cm).

\section{Interpretation}

Facies 5 is mainly composed of clast-supported deposits that appear to be the product of disaggregation of slump and/or slide blocks as they moved downslope. The occurrence of both matrix- and clastsupported intervals suggest that these deposits may represent the transitional phase from slumps/slides into debris flows. Some large clasts appear to be composed of matrix material containing smaller clasts. The occurrence of clasts within clasts suggests that at least some of the clasts in this deposit represent two or more cycles of mass-wasting events. The breccia and conglomerate deposits of Facies 5 are apparently debris eroded from the slope as a result of multiple failures.

Manned submersible observations, and deep-sea photography of the New Jersey and the Monterey, California, lower slopes revealed detachment surfaces and slope canyons with extensive talus deposits at the base of headwall scarps (McHugh et al., 1992, 1993). Talus blocks are piled on top of each other and range in size from very small $(1 \mathrm{~cm})$ to very large $(>10 \mathrm{~m})$. Blocks can be subrounded to angular in shape, and are extensively fractured. These observations are consistent with the features that characterize Facies 5-that is, fractured and angular blocks of different sizes, clast- and matrix-supported breccias, and abruptly dipping contacts.

Microfaults, as well as clastic injections, suggest that the deposits were overpressured and in a state of stress. High pore pressures could have resulted from rapid loading of the sediment by subsequent masstransport deposits. Facies 5 apparently shows that at least six consecutive mass-wasting events occurred during formation and widening of the canyon floor and walls (Fig. 3). A possible sequence of events for the deposition of Facies 5 is that once the initial slope failure occurred, later episodes of mass transport were directed by gravity toward the scar in the dissected slope leading to continued excavation and widening of the canyon. Some of the mass-transport deposits derived from the upper slope and/or the canyon walls were preserved on the floor of the canyon at Site 906.

\section{Facies 6: Interbedded Sands, Silts, and Silty Clays with Thin Intervals of Soft-Sediment Deformation}

Facies 6 occurs at Site 906 (421-376 mbsf) and consists of laminae and thin beds of sands and silty clay, which form one 45-m-thick thinning-upward and fining-upward unit. Sand beds are $1-5 \mathrm{~cm}$ thick at the base of the unit and thin upward to 1- to 10-mm laminae near the top (Fig. 14A, B). The sands are fine-grained and contain wellsorted quartz, mica flakes, and abundant wood fragments. The beds toward the base of the sequence have sharp, scoured bases, and possibly ripple cross-lamination. The sands are interbedded from the base to the top of the unit with silt, silty clay, and clay laminae. This unit also contains thin intervals of soft-sediment deformation with isoclinal folds, dipping contacts, and subrounded clay clasts a few millimeters to centimeters in diameter (Fig. 14C). The soft-sediment deformation features are highlighted by color variations in shades of greenish-gray to yellowish-gray. These thin intervals affected by softsediment deformation appear to represent small, localized masstransport events of slumping and debris flows. Terrestrial plant matter is abundant in Facies 6. Interbedded sands, silts, and silty clays of Facies 6 also occur at Site 904 between 216 and 221 mbsf.

\section{Interpretation}

Facies 6 is interpreted as having been deposited by multiple turbidity currents. The sand laminae and beds appear to show a finingand thinning-upward cycle. This cycle suggests a shoreward shift of the source area. Possibly, when the slope canyon was initially formed, turbidity currents bypassed this portion of the canyon and deposited sediment farther downslope or on the continental rise. As the source retreated shoreward or the strength of the flows diminished, turbidite deposition occurred at this location in the canyon. Because the turbidites have abundant quartz and plant matter, the source for the turbidity 
A

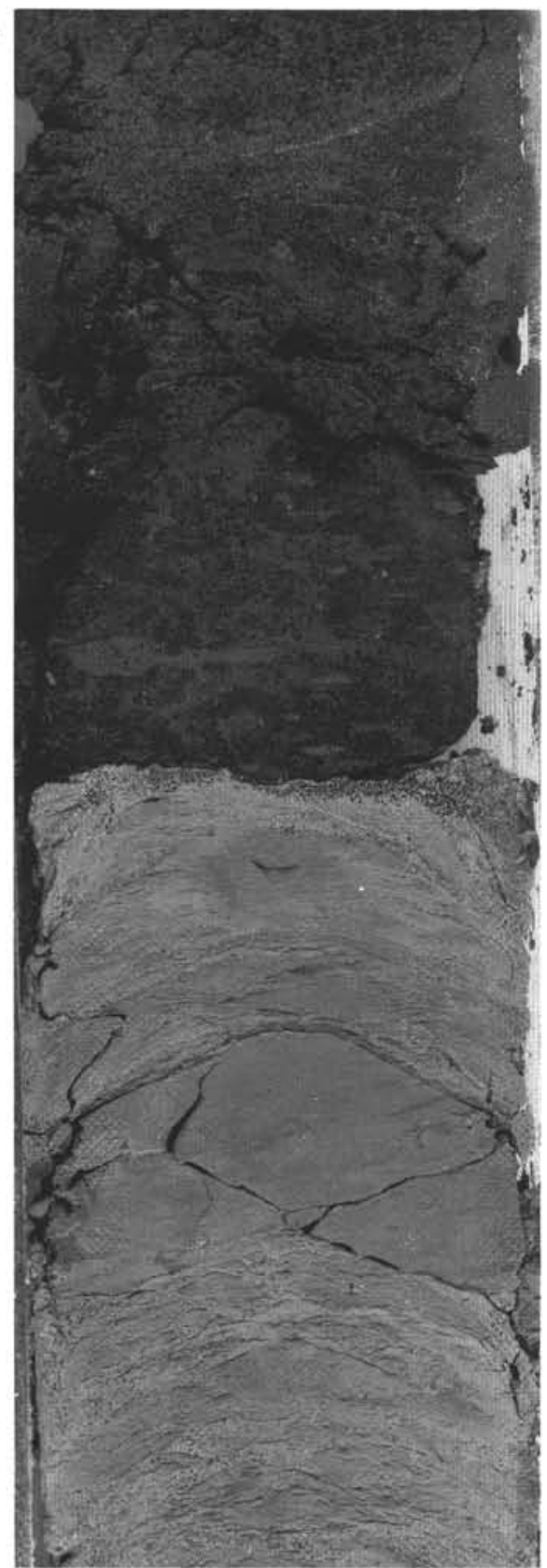

B

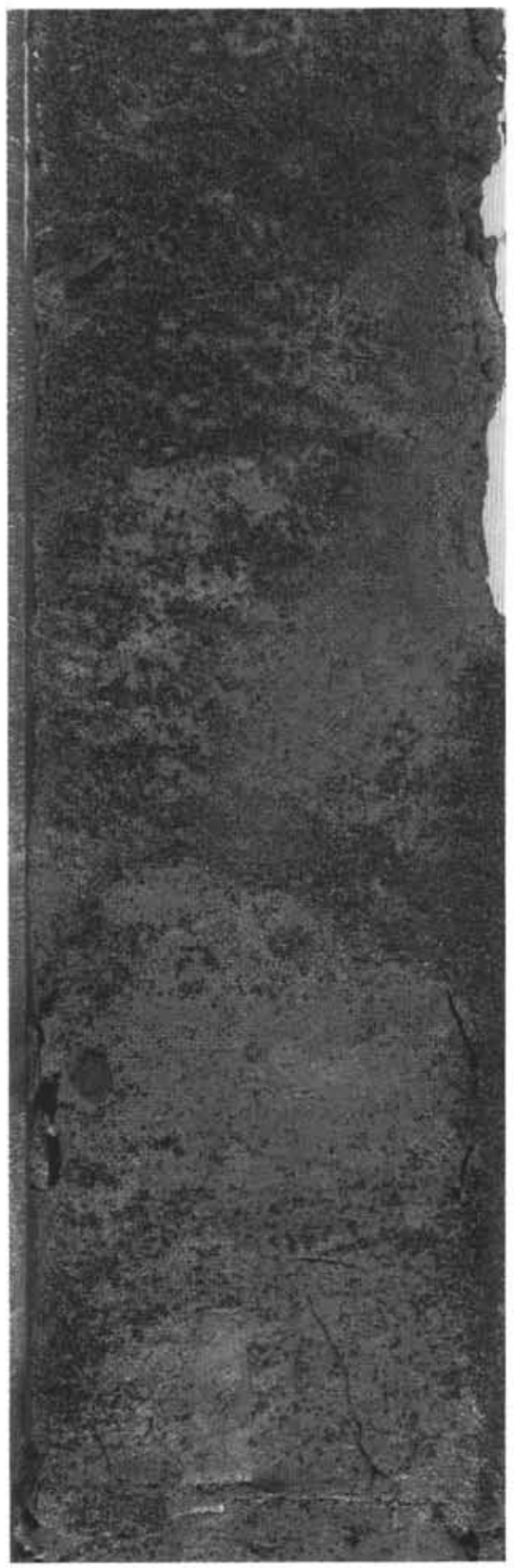

Figure 10. Some zones of disseminated glauconitic sands and silts of Facies 2 are associated with unconformities. A. A major erosional surface separates the late Eocene biosiliceous chalks from the late Oligocene terrigenous silty clays in Hole 902D. Disseminated glauconite is abundant in the late Oligocene sediment (Interval 150-902D-74X-1, 64-84 cm). B. The late Eocene to late Oligocene unconformity is not as abrupt in Hole 904A as it is in Hole 902D. Disseminated glauconite occurs above the unconformity in the late Oligocene sandy silty clays (Interval 150-904A-37X-3, 115-135 cm).

flows was terrigenous, possibly a river. Glauconites, which would indicate a shallow-marine environment, are rare to absent.

\section{Facies 7: Laminated Clays with Diagenetic Siderite}

Facies 7 also occurs only at Site 906 (from 376 to $300 \mathrm{mbsf}$ ) and is composed of one 65 -m-thick unit of olive gray silty clay with interbedded buff-colored siderite laminae of diagenetic origin (Fig. 15). Veins of quartz sand and microfaults crosscut the laminated clays. The silty clay intervals are 1 to $10 \mathrm{~cm}$ thick between siderite laminae. The siderite laminae are progressively less developed toward the top of the unit and gradually disappear. The transition from the underlying turbidites of Facies 6 to the silty clays takes place throughout a $7-\mathrm{m}$ interval, which also contains a few thin intervals with soft-sediment deformation features including contorted, folded laminae and zones of angular to rounded mud clasts.

\section{Interpretation}

The silty clays of Facies 7 are interpreted as hemipelagic and pelagic deposition. Sediment recovered from other Deep Sea Drilling Project legs along the North Atlantic continental margins reveals that siderite is quite common (von Rad and Botz, 1987; Jansa et al., 1979; Lancelot et al., 1972). In general, siderite is precipitated during early diagenesis in rapidly deposited hemipelagic clays rich in organic 
A

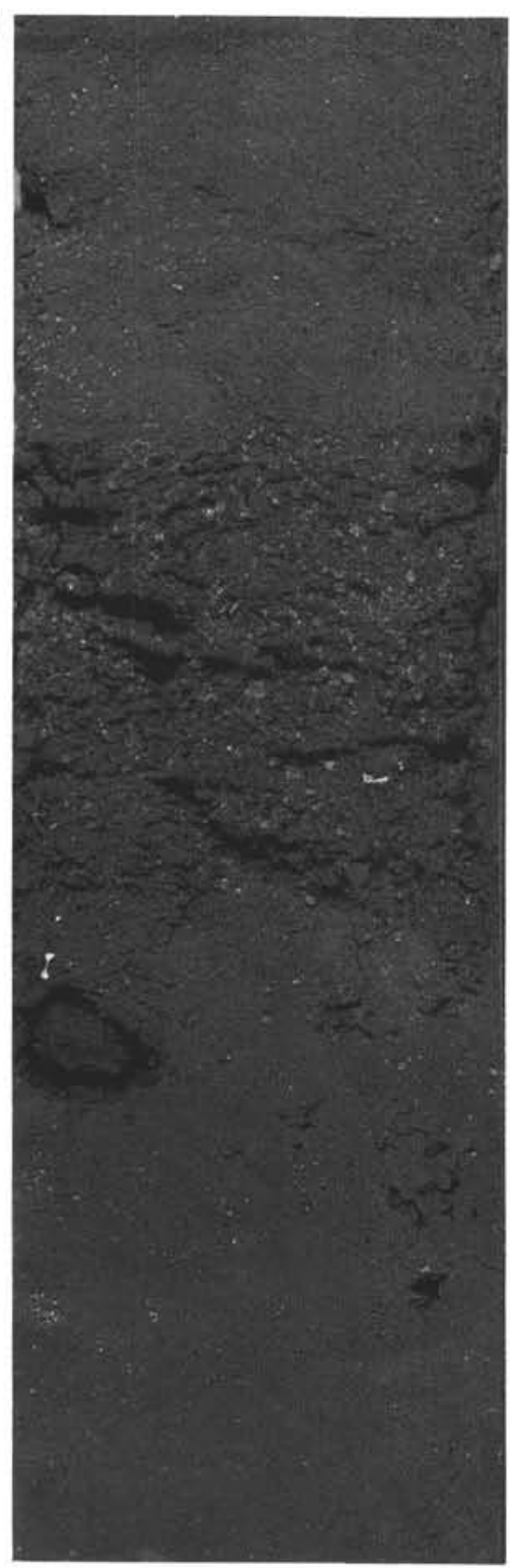

B

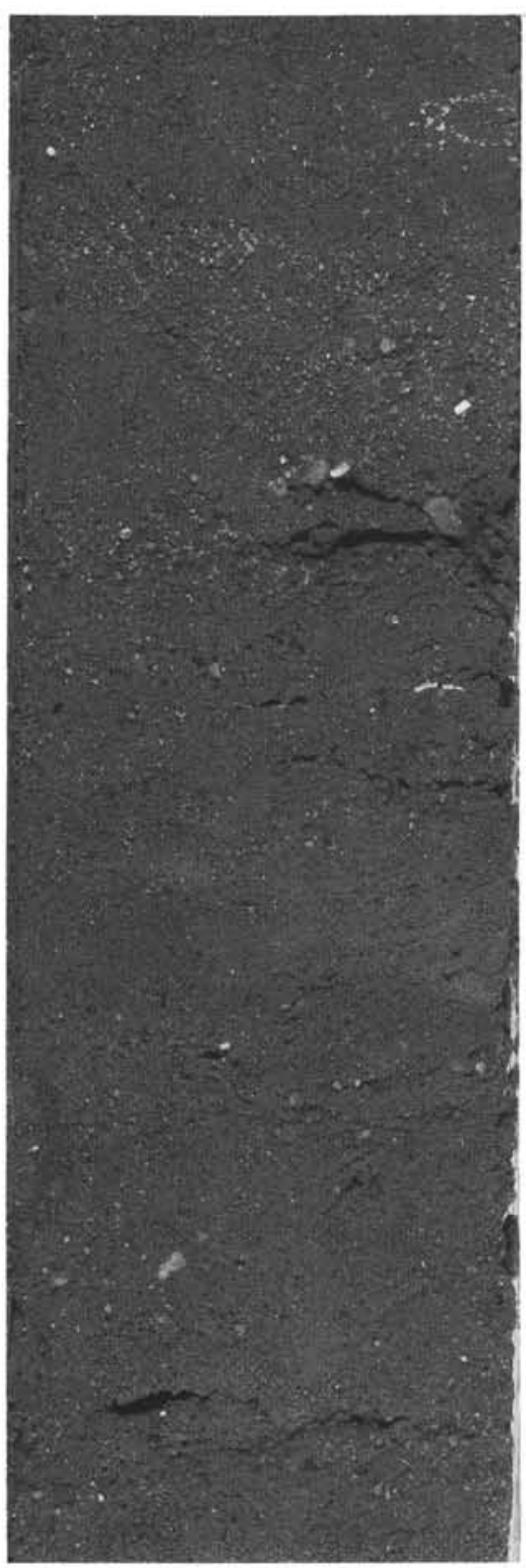

C

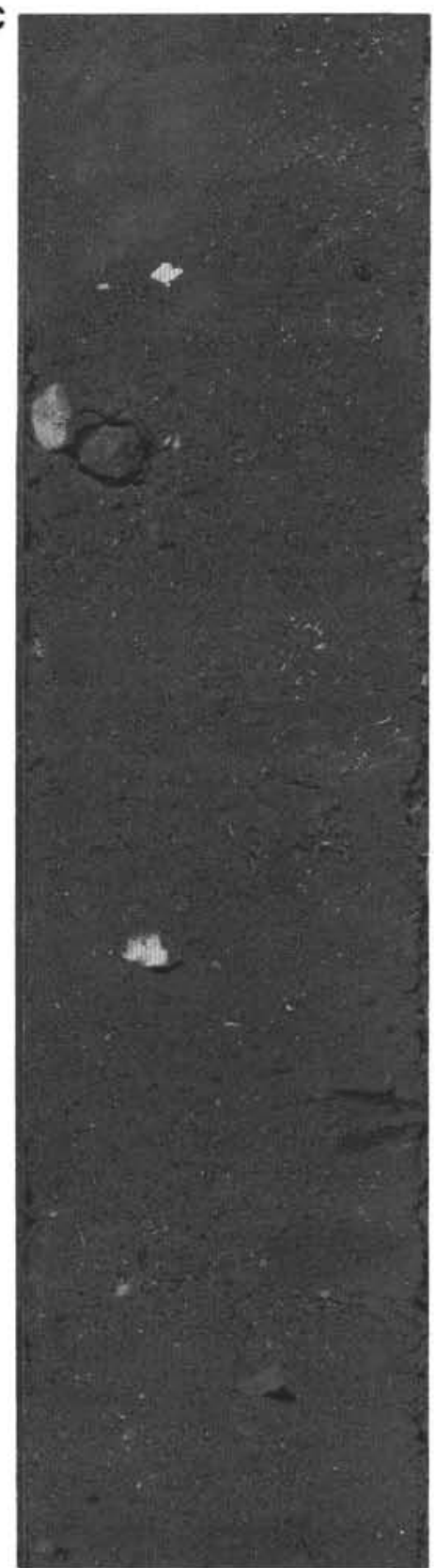

Figure 11. Examples of Facies 3: fine- to coarse-grained sands that contain clay and lithic clasts of Paleocene to Pleistocene age. A. Coarse-grained sands, granules, and clay clasts (Interval 150-903A-39X-2, 25-45 cm). B. Clay clasts of diverse ages "floating" in the sandy matrix; note clast rims contain fine- to coarsegrained sands (Interval 150-903A-39X-2, 55-75 cm). C. Quartz, chert, pyrite, and other detrital granules in sandy matrix (Interval 150-903A-39X-4, 45-70 $\mathrm{cm})$.

matter. This suggests that the siderite laminae of Facies 7 were formed as a result of high sedimentation rates and high organic contents. However, because of the laminated character of Facies 7, it is possible that the rapidly deposited, organic-rich sediment was accumulated episodically or in pulses. This suggests that the episodic influxes of organic-rich sediment were related to a continued shoreward shift of the terrigenous source that contributed to the deposition of the Facies 6 turbidites. Continued shoreward retreat of the source or diminishing strength of the flows would explain the fining-upward sequence from sandy turbidites of Facies 6 to laminated clays of Facies 7. The occurrence of clastic dikes and microfaults suggests that the sediment was overpressured, perhaps as a result of high sedimentation. The thin intervals affected by soft-sediment deformation ap- pear to represent small, localized mass-transport events of slumping and debris flows.

\section{Facies 8a: Deformed Silty Clay with Clay and Lithic Clasts of Variable Ages Different from the Age of the Matrix}

Facies $8 \mathrm{a}$ consists of a single 50-m-thick unit at Site 906 (55-5 mbsf) composed of predominantly deformed silty clay with clay and lithic clasts (Fig. 16). A defining characteristic of Facies 8a is that the clasts have variable ages that are different from the age of the surrounding matrix. This diversity of clast vs. matrix ages is a major difference between this facies and Facies 1 (above), which has clasts and matrix of the same age. Other main differences between Facies 8a 

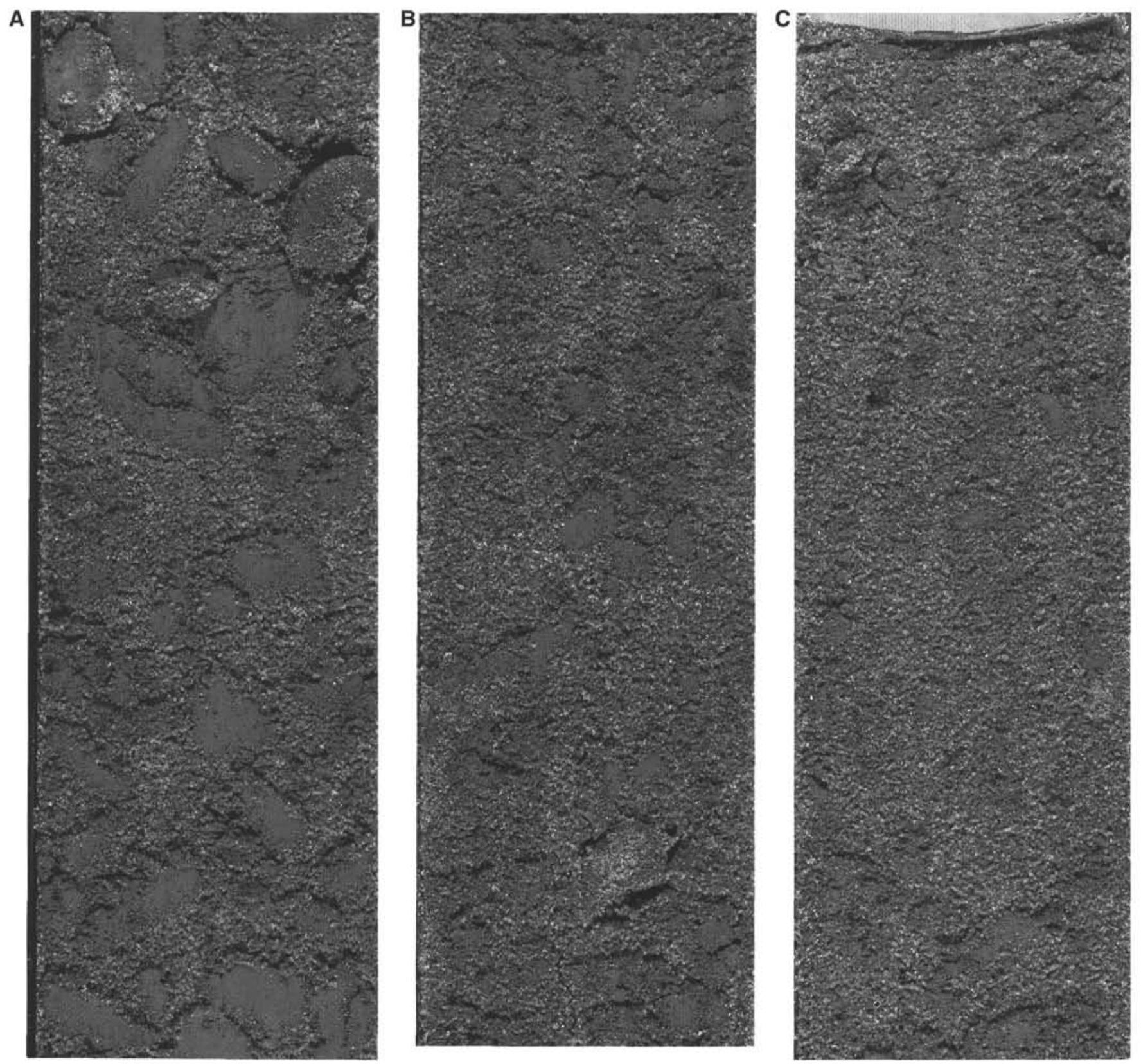

Figure 12. Examples of Facies 4: normally graded sand and mud clasts. A. Subrounded to well-rounded clay clasts in a coarse sand matrix (Interval 150-903B$16 \mathrm{H}-7,60-80 \mathrm{~cm}$ ). B, C. Normally graded mud clasts (Intervals 150-903B-16H-7, 20-40 and 0-20 cm, respectively). D. Sands containing "floating" granules (Interval 150-903B-16H-6, 110-130 cm).

and 1 are that (1) kaolinite and chlorite (diagnostic of the Miocene and Pleistocene sediments, respectively) occur mixed in Facies 8a, (2) the carbonate content of the clasts of Facies 8a varies (from up to $20 \%$ for the Pleistocene to $<0.25 \%$ for presumably the upper Miocene), and (3) the matrix of Facies 8a is rarely deformed or contorted, especially compared to the matrix of Facies 1 . The top $40 \mathrm{~m}$ of this unit is composed of Pleistocene silty clays, glauconitic silty clays, and sandy silts that contain clay and lithic clasts. Clay clasts range in size from $<1$ to $>50 \mathrm{~cm}$ in diameter. The clay clasts are predominantly subrounded, with well-defined boundaries and contain kaolinite, chlorite, and mixed kaolinite and chlorite. The clasts, as well as the matrix, range in color from dark gray to olive gray to greenish gray. The lithic clasts in Facies $8 \mathrm{a}$ are the largest recovered, and range from 1 to $6 \mathrm{~cm}$ in diameter. Clay clasts can also be very large (up to $60 \mathrm{~cm}$ ).
Pebble-sized bioclasts, such as gastropod and bivalve shells, are also common. Silt-sized quartz and feldspar are common in the uppermost portion of the unit. The bottom $10 \mathrm{~m}$ of Facies $8 \mathrm{a}$ consist of predominantly glauconitic silts and sands of late Miocene age.

\section{Interpretation}

Facies 8a is interpreted as a series of muddy debris flows that filled Berkeley Canyon. The mixing of ages and lithologies of the clasts and matrix of Facies 8a sediment suggests that these masstransport deposits were derived from deep excavation in a canyon setting. The occurrence of large and undeformed clay clasts suggests that some of the material found in Facies $8 \mathrm{a}$ is locally derived from the canyon walls. The sources of the sediments in the debris flows are terrigenous and shallow marine. Because the terrigenous compo- 


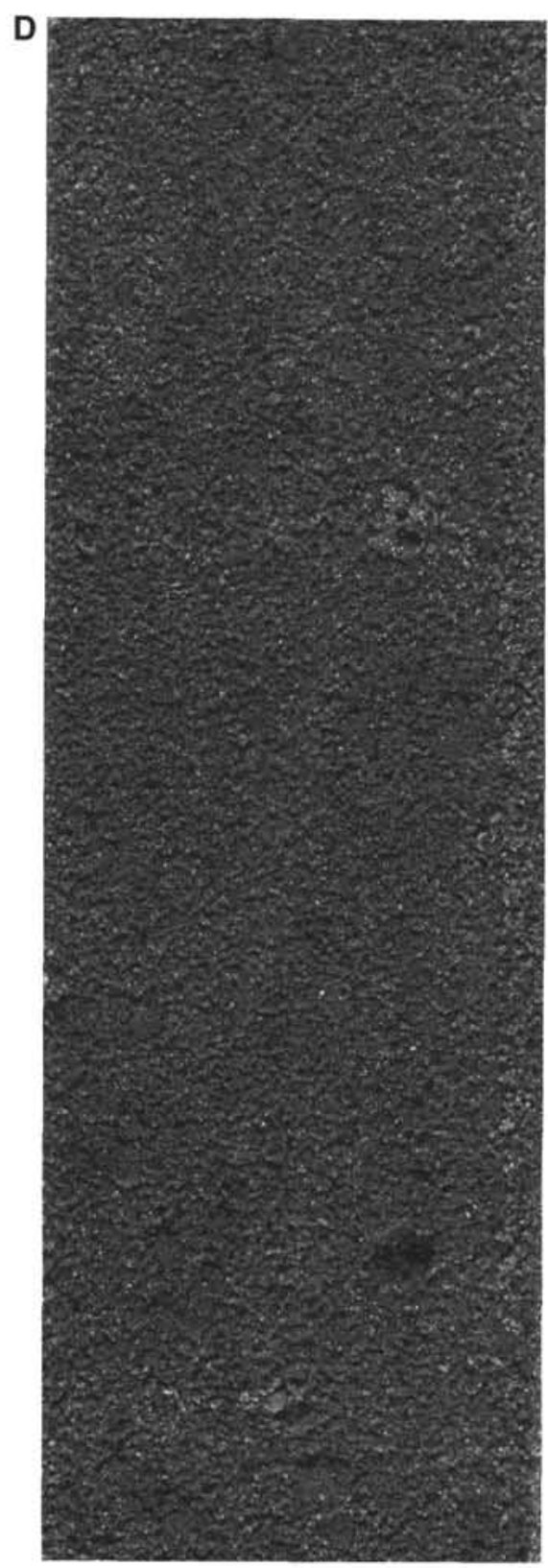

Figure 12 (continued).

nents, such as quartz and feldspar, are dominantly silt-sized, the terrigenous source was probably not near this drill site.

\section{Facies 8b: Contorted Silty Clays with Chalk, Clay, and Lithic Clasts of Variable Ages Different from the Age of the Matrix}

Facies $8 \mathrm{~b}$ is characterized by a silty-clay matrix with well-developed soft-sediment deformation features and clasts of diverse lithologies, ages, sizes, and degrees of induration (Fig. 17). Facies $8 \mathrm{~b}$ is common at continental rise Site 905 from 220 to 20 mbsf. Deformation features include contorted, discordant, and dipping beds of variegated colors that range from light to dark grays, green to greenish grays, and brown to brownish grays. Isoclinal and recumbent folds, as well as diffuse features, are common. Facies $8 \mathrm{~b}$ differs from Facies $8 \mathrm{a}$ in that it (1) contains white Eocene carbonate clasts, (2) shows a much higher degree of soft-sediment deformation, (3) has some clasts involved in more than one episode of transport, and (4) contains a much greater range in clast age, size, and mineralogy.

Clasts range in size from $<1 \mathrm{~cm}$ to $>10 \mathrm{~cm}$. Clasts are composed of a variety of grain sizes ranging from clay to sand. The clay content within the clasts is representative of all clays sampled in the slope holes including kaolinite, chlorite, illite, minor smectite, and mixed clay illite-smectite and the carbonate content of the clasts varies from $<0.25 \%$ to $40 \%$. This variety of mineralogies is indicative of the wide range of sediment ages and lithologies observed on the slope. Indurated clasts range in size from sand to pebble and are primarily composed of quartz and pyrite. Bioclasts include shell fragments. A quartz sandstone clast is cemented with aragonite, indicating an unusual (possibly gas-mediated) diagenetic history. Some clasts appear to be enclosed in larger clasts and, thus, show evidence of having been involved in at least two episodes of mass transport. Clay and chalk injections are common.

The clasts in the Pleistocene mass-transport deposits are middle Eocene, middle Pliocene, late Pliocene, and Pleistocene in age. Some kaolinite-rich clasts are barren, which suggests a late middle to late Miocene age. The age of the matrix in these deposits is consistently early Pleistocene. Episodes of mass transport are separated by silty-clay intervals $2.5 \mathrm{~m}$ thick at $45 \mathrm{mbsf}, 8 \mathrm{~m}$ thick at $99 \mathrm{mbsf}$, and $6 \mathrm{~m}$ thick at $126 \mathrm{mbsf}$. Sand is not abundant, but rarely occurs as discrete laminae, $1 \mathrm{~mm}$ to $1 \mathrm{~cm}$ thick, and disseminated in some intervals of sediment. Only two thick sand beds were recovered: an 8$\mathrm{m}$-thick bed at $72 \mathrm{mbsf}$ and a 5 -m-thick bed at $185 \mathrm{mbsf}$.

\section{Interpretation}

Facies $8 \mathrm{~b}$ is interpreted as muddy slumps and debris flows that were transported through a slope canyon, where they entrained an abundance of clasts of diverse age, size, and mineralogy. Based on the soft-sediment folds, injections, and other structures two or more episodes of mass-transport occurred in some of the Facies 8b deposits.

\section{Facies 9: Clast-Supported Conglomerate}

Facies 9 comprises an interval of clast-supported conglomerate that is approximately $15 \mathrm{~m}$ in thickness at Site 905 on the continental rise (680-665 mbsf; Fig. 18). Most clasts are angular to subangular, but subrounded to rounded clasts also occur. Sizes range from $<1 \mathrm{~cm}$ to $>50 \mathrm{~cm}$. Clasts represent a variety of lithologies and exhibit a wide variety of colors. Clasts are often bounded by steeply dipping microfaults. Ages of clasts range from middle Eocene to middle Miocene. Some clasts are composed of gray sandy clay, which show evidence of soft-sediment deformation and contain smaller clasts within them. These features suggest that the sandy clay clasts were originally derived from the matrix material of an older mass-transport deposit; hence, some of the material in Facies 9 may have been involved in at least two episodes of mass transport.

The benthic foraminiferal assemblages contained in the clasts could have been deposited in water depths anywhere within the neritic to lower bathyal zones. The predominant faunal assemblages indicate deposition in the middle and lower slopes (600-2000 m). However, some faunal components indicate more than one episode of transport from the neritic zone $(<200 \mathrm{~m})$, and others are similar to the depauperate Miocene assemblages from the upper slope at Site $903(450 \mathrm{~m})$.

\section{Interpretation}

The clast-supported nature of this facies, along with the microfaults and soft-sediment deformation, suggests that this facies represents a slump or debris-flow deposit, possibly a transitional phase from one to the other. The occurrence of smaller clasts within larger clasts indicate two, or in some cases, three separate episodes of masswasting events are recorded. Benthic foraminifer assemblages indi- 
A

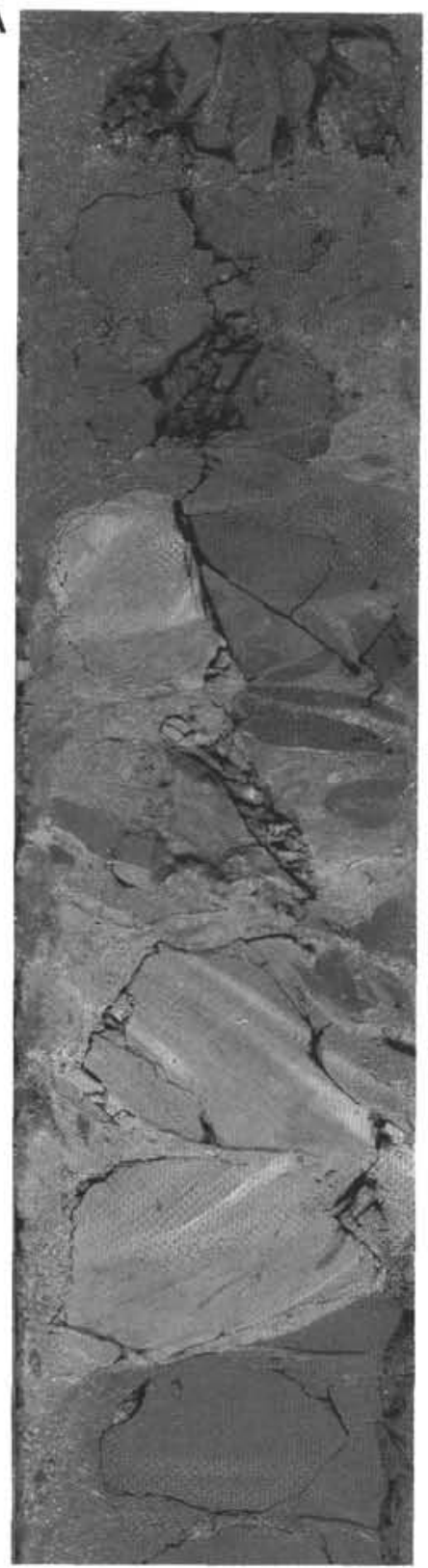

B

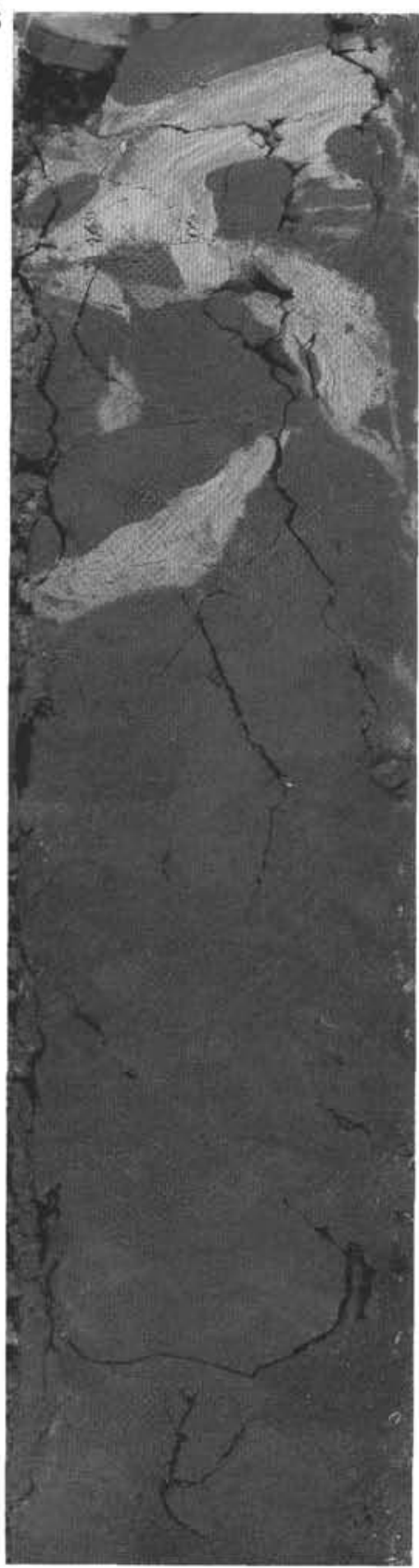

C

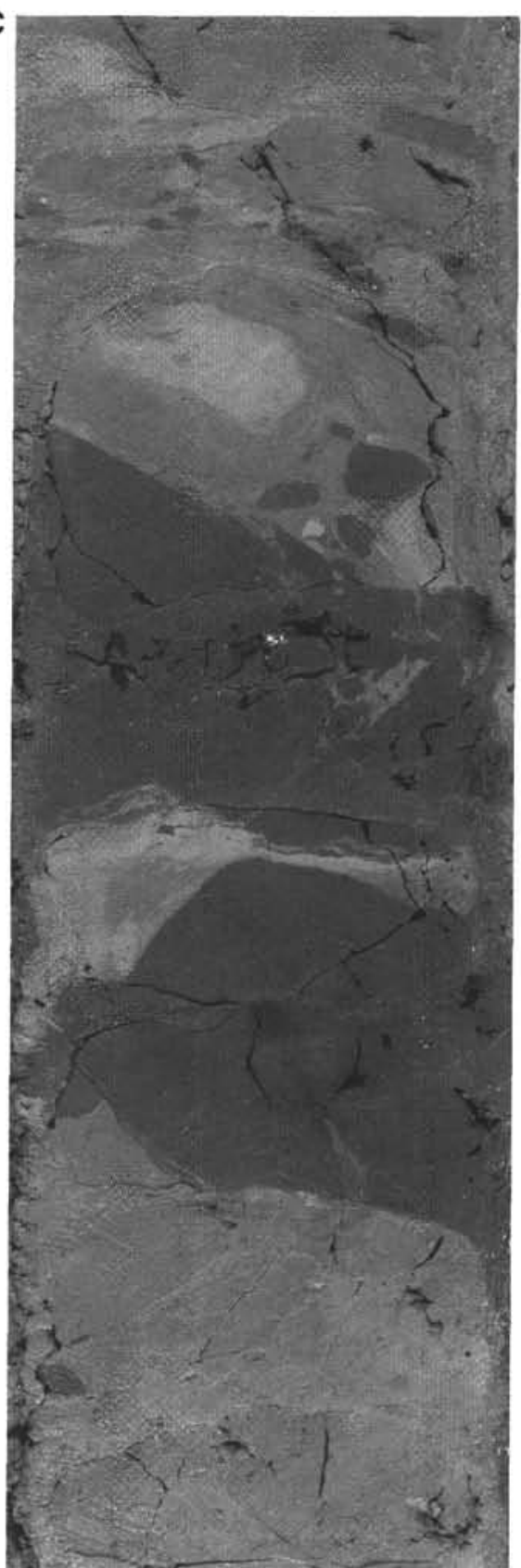

Figure 13. Examples of Facies 5: breccias and conglomerates. A. Angular-dipping contacts separate breccias from dark brown silty clays. Note the light gray breccia clast contains soft-sediment deformation features and angular dark brown silty clay clasts. This occurrence of clasts within the breccia clast indicates more than one episode of mass wasting (Interval 150-906A-48X-3, 75-100 cm). B. Zones of injected material with smaller clasts (Interval 150-906A-48X-4, 0$25 \mathrm{~cm}$ ). C. Angular and fractured clasts bounded by angular-dipping microfaults (Interval 150-906A-46X-3, 70-90 cm).

cate that these deposits could have been transported from the upper to the middle slope and then to the continental rise or from the middle and lower slopes to the continental rise.

\section{CORRELATION OF DEPOSITS TO SURFACES AND BOUNDARIES BENEATH THE CONTINENTAL SLOPE AT SITES 902-904}

The sources and transport processes of the mass-wasting deposits and their implications for the erosional history of the New Jersey Margin can be interpreted based on these nine sedimentary facies ob- served. In many cases, these sedimentary facies can apparently be correlated to sequence boundaries interpreted from seismic reflections at slope Sites 903, 902, 904, and 906. This leads to the possibility that the relationship between mass-transport deposits and eustatic sea-level changes (Tables 1, 3; Figs. 2, 3) can be evaluated. On the continental rise the sedimentary facies of Site 905 are related to seismic reflections of Mountain and Tucholke (1985).

\section{Site 903}

Mass-wasting and gravity-flow deposits are best preserved, thicker, and more numerous in Site 903 beneath the upper slope than in 


\section{A}

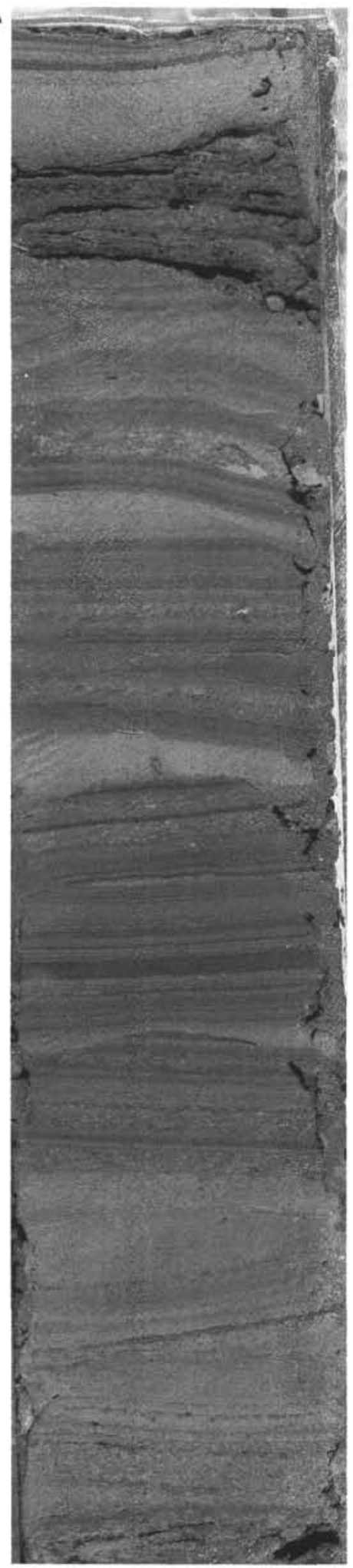

B

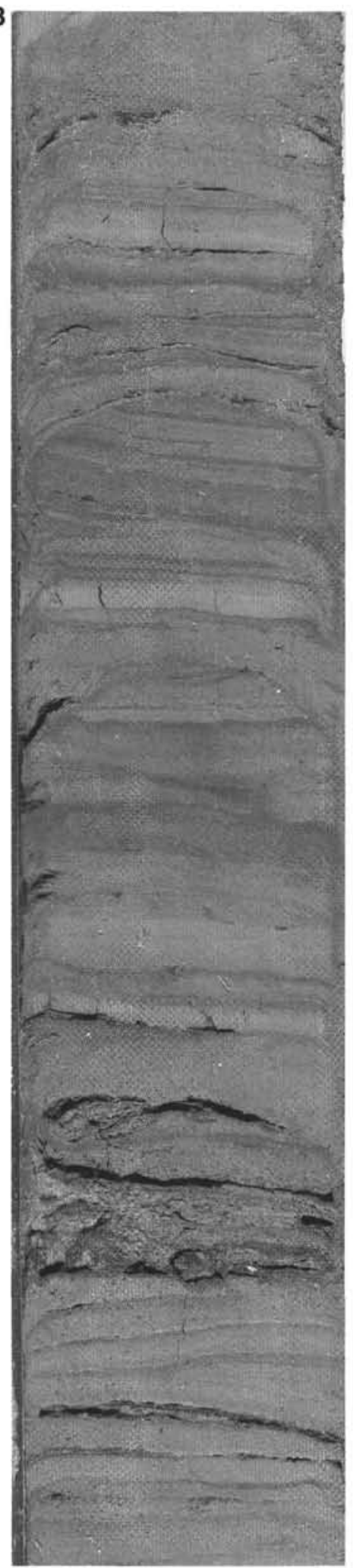

C

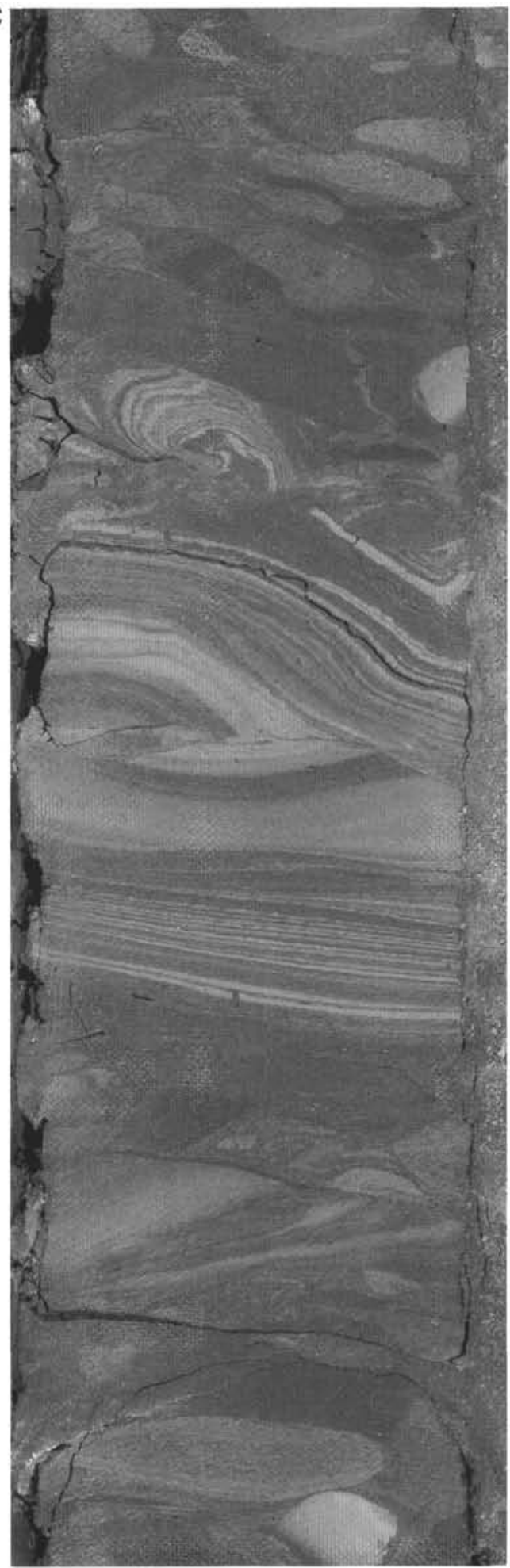

Figure 14. Examples of Facies 6: sand, silt, and silty clay laminae and beds. A. Laminated sands, silts, and silty clays. Sand beds are 2 to $5 \mathrm{~cm}$ thick ( $25-30 \mathrm{~cm}$ and 3-5 cm) (Interval 150-906A-45X-2, 0-30 cm). B. Rare thin sand laminae characterize upper part of the unit (1 cm thick at 73-74 cm); silt and clay laminae predominate (Interval 150-906A-41X-2, 50-80 cm). C. Thin intervals of soft-sediment deformation (Interval 150-906A-40X-3, 100-120 cm). 

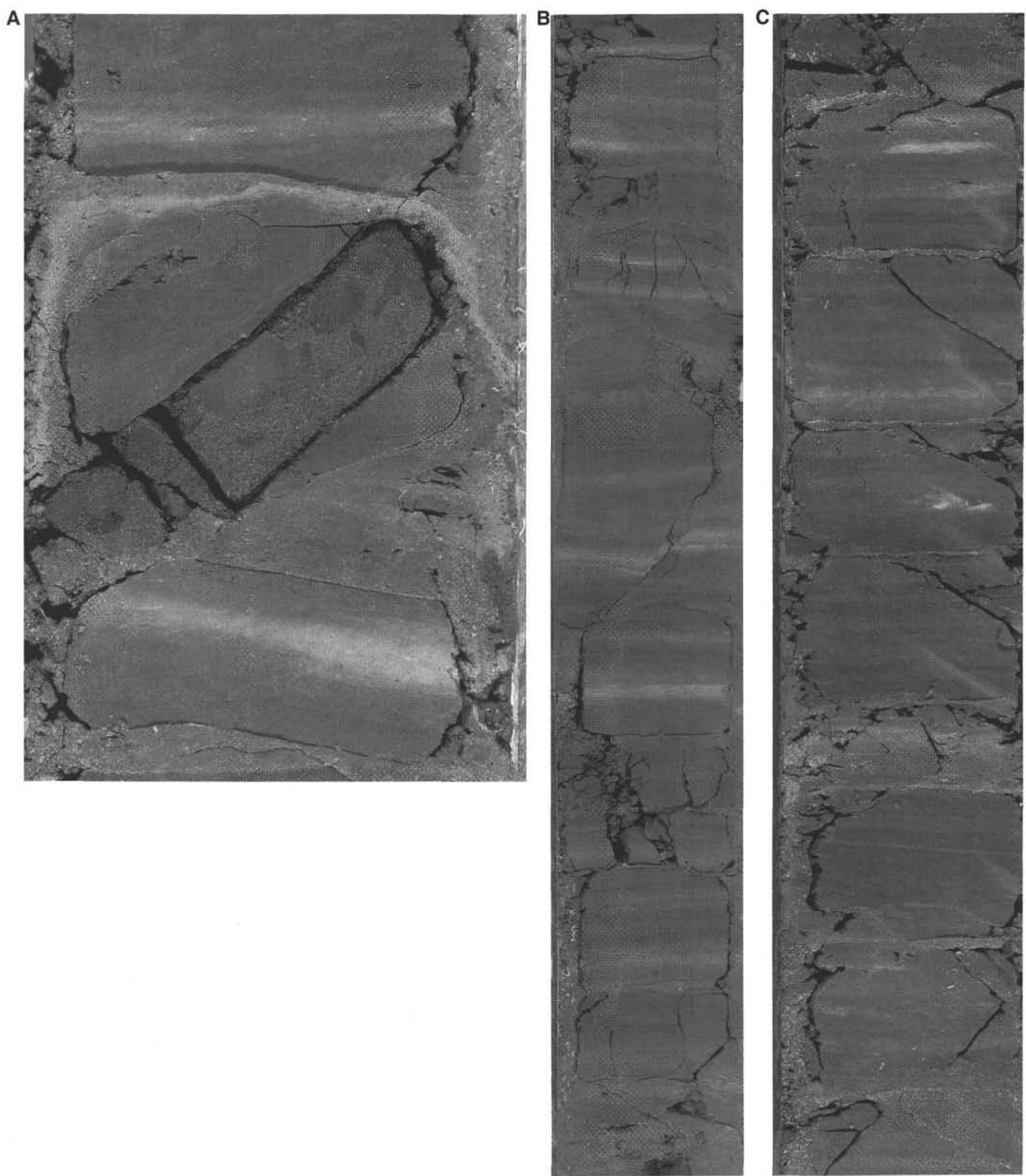

Figure 15. Examples of Facies 7: laminated clays. A. Clays with interbedded siderite laminae. A vein composed of coarse sand and clay chasts cross-cuts the laminated clays (Interval 150-906A-35X-4, 75-85 cm). B. Steeply dipping microfaults in laminated clays (Interval 150-906A-34X-5, 50-90 cm). C. Siderite laminae gradually disappear toward the top of the section (Interval 150-906A-33X-2, 105-135 cm). 
A

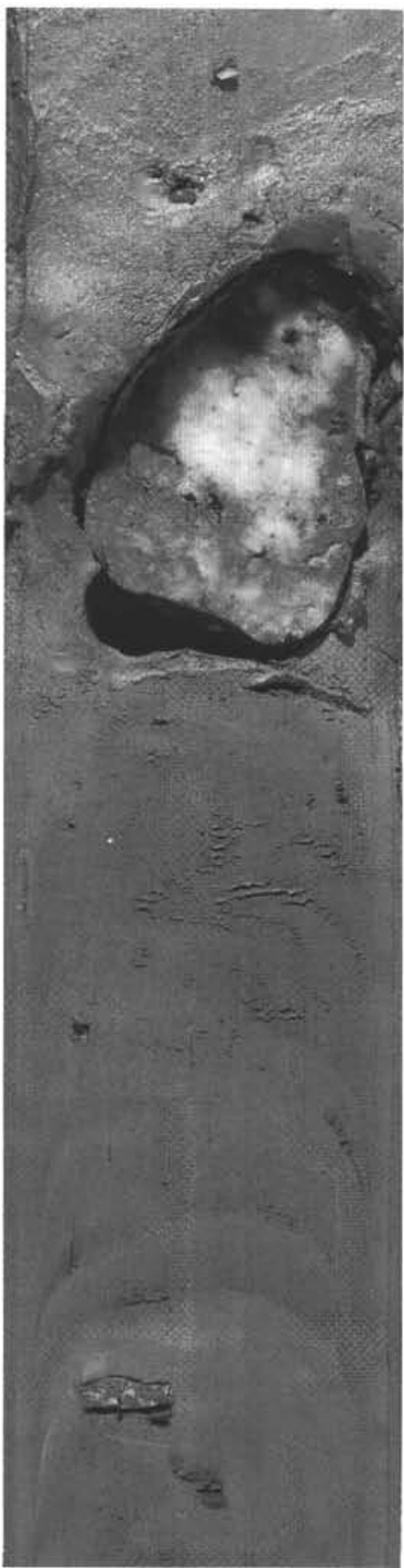

B

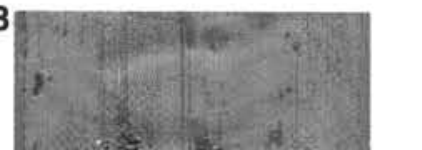

\section{.}
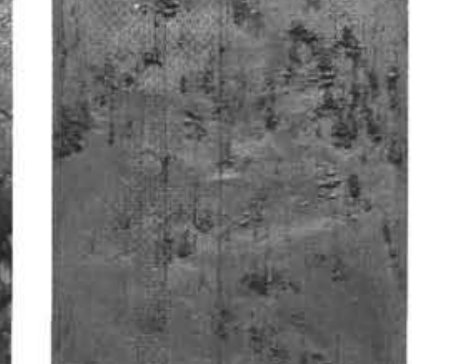

A sandy mass-flow consisting of Facies 3 occurs from 337 to 359 mbsf. The matrix of this unit was dated successively upward from the base as upper Miocene, Pliocene, late Pliocene, and middle Pleistocene. These ages suggest that this unit actually represents a series of mass-transport events separated by erosional intervals. The New Jersey coastal plain or shelf is thought to be the source of these deposits. Seismic reflection, p6 (359 mbsf), correlates with a sandy mass flow at the base of the Pliocene.

Middle to upper Miocene deposits of Facies 2 are present in the intervals of 369-392 mbsf, 403-404 mbsf, 421-429 mbsf, 440-459 mbsf, 487-493 mbsf, 500-520 mbsf, and 578-581 mbsf (Figs. 2, 19). The sandy deposits of Facies 2 correlate to seismic reflectors m0.3 yellow (405 mbsf), and $\mathrm{m} 0.5 \mathrm{Red}$ ( $520 \mathrm{mbsf}$ ).

Slump and debris-flow deposits of Facies 1 are volumetrically less significant in the $554 \mathrm{~m}$ section of middle to upper Miocene sediment than in the Pleistocene. Middle Miocene deposits are present in the intervals 602-604.5 mbsf, 622-624.5 mbsf, and 731-733 mbsf. Mass-transport deposits of Facies 1 and 2 occur at the bases of sequences and rest upon sequence boundaries correlated to seismic reflections $\mathrm{ml}$ (604.5 mbsf) and $\mathrm{ml} .5$ (624.5 mbsf). Disseminated sands of Facies 2 occur sporadically through the middle to upper Miocene, and in some instances, intervals with these disseminated sands appear to correlate with prominent seismic reflections. Facies 2 correlates with $\mathrm{ml} .5$ orange at $624.5 \mathrm{mbsf}, \mathrm{ml}$ Tuscan at 604.5 mbsf.

Sands of Facies 2 are the only type of deposit preserved in the early Miocene ( $67 \mathrm{~m}$ thick) and in the late Oligocene ( $58 \mathrm{~m}$ thick). Glauconitic silty sandstone of Facies 2 occurs disseminated near seismic reflections $\mathrm{m} 6$ and o1. Except for an influx of silt-sized particles, mass-wasting and gravity-flow deposits were not observed in the Eocene ( $86 \mathrm{~m}$ thick).

A correlation between mass-transport deposits of Facies 1-4 to sequence boundaries occurs in the upper Miocene and Pleistocene. However, mass-transport deposits of Facies 1-3 also occur within the sequences. The correlation between mass-transport deposits of $\mathrm{Fa}$ cies 1-2 and sequence boundaries is minor from the upper Oligocene to the upper Miocene. Mass-transport deposits of Facies 1-4 are a small component, $\sim 13 \%$, of the total sediment recovered at Site 903 $(1150 \mathrm{~m})$. The rest of the sediment predominantly consist of hemipelagic clays, silty clays, sandy silts, and pelagic biosiliceous chalks.

\section{Site 902}

Mass-transport deposits of Facies 1 predominate in the Pleistocene section at Site 902 beneath the middle slope (Figs. 3, 20; Table 3 ). The middle Pleistocene section is $126 \mathrm{~m}$ thick and Facies 1 deposits occur in the intervals 7-19 mbsf in Hole 902C; 12-22 mbsf, 4447 mbsf, and 98-106 mbsf in Hole 902D; 110-122 mbsf in Hole 902C; and 113-121 mbsf in Hole 902D. The bases of these deposits were correlated to seismic reflections p1 ( $22 \mathrm{mbsf}), \mathrm{p} 2$ ( $47 \mathrm{mbsf})$, and p4 (122 mbst).

Facies 2 is rare in the Pleistocene, but where present, consists pre-

Figure 16. Examples of Facies 8a: silty clays with clay and lithic clasts. A. Large (7 cm diameter) lithic fragment in fine-grained matrix (Interval 150$906 \mathrm{~A}-2 \mathrm{H}-5,40-65 \mathrm{~cm})$. B. Large clast $(47-63 \mathrm{~cm})$ separated by a sharp contact from the rest of the debris flow (Interval 150-906A-2H-7, 30-60 cm).

any other slope site. The middle to upper Pleistocene section in Site 903 is 359 m thick and contains mass-transport and gravity-flow deposits of Facies 1 and 2 in the following intervals: 119 to $121 \mathrm{mbsf}$, 125 to $142 \mathrm{mbsf}, 209$ to $210 \mathrm{mbsf}, 221$ to $231 \mathrm{mbsf}, 241$ to $244 \mathrm{mbsf}$, 246 to $247 \mathrm{mbsf}, 269$ to $274 \mathrm{mbsf}, 298$ to $307 \mathrm{mbsf}$, and 326 to 327 mbsf (Figs. 2, 19; Table 3). Facies 4 occurs between 142 and 145 mbsf. The bases of mass-transport deposits of Facies 1, 2, and 4 appear to correlate with the prominent seismic reflections (sequence boundaries) p2, p4, and p5 (Fig. 19). dominantly of disseminated quartz sands and these sand beds occur in association with mass-transport deposits. In contrast, Facies 2 is predominant in the Miocene where it is characterized by glauconite during the lower, lower middle, and upper Miocene (Figs. 3, 20). Facies 2 appears to correlate to seismic reflections ml Tuscan ( 290 mbsf), m2 Yellow-2 (407 mbsf), m5 Green (523 mbsf), m5.4 sand (568 mbsf), and $\mathrm{m} 6$ pink-3 (614 mbsf). Late Miocene quartz and glauconite deposition is volumetrically less significant $(30 \%)$ in this location than beneath the upper slope, where abundances reach $80 \%$. The middle to upper Miocene is characterized by abundant plant matter, which correlates with a decrease in carbonate content of the sediment, and sporadic glauconite sand deposition. Intervals of sandy silt and glauconite sandy silt deposition correlate with some seismic reflections in the lower to upper Miocene. Glauconite sandy silt also 

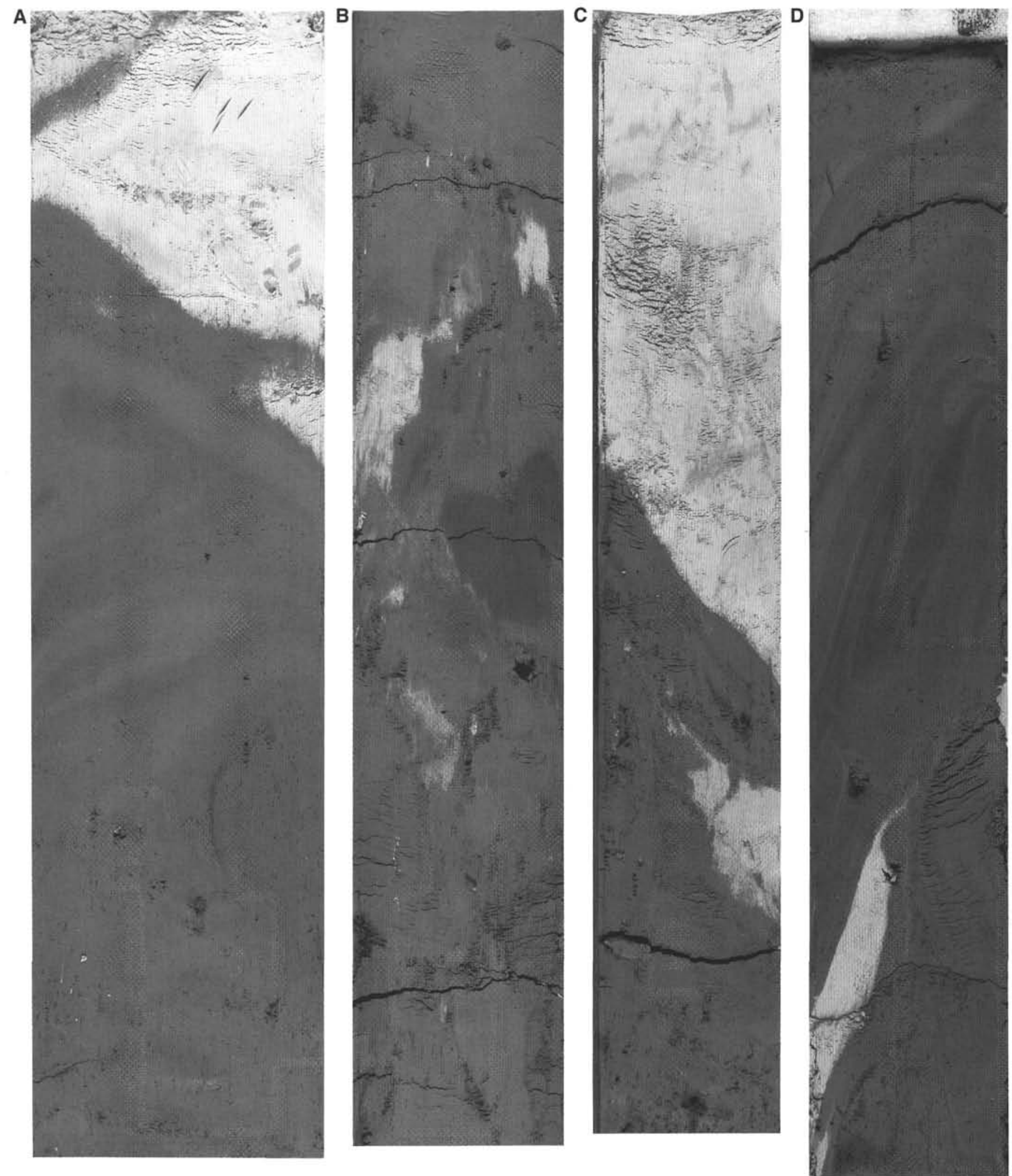

Figure 17. Examples of Facies 8b: contorted silty clays with clasts of diverse ages, lithologies, sizes, and degrees of induration. A. Isoclinal folds, flowage features, and large middle Eocene chalk clast (Interval 150-905A-3H-2, 0-25 cm). B. Deformed clasts of various ages and lithologies (Interval 150-905A-9H-4, 65-100 cm). C. Large middle Eocene clasts in lower Pleistocene matrix (Interval 150-905A-9H-5, 0-40 cm). D. Flowage features, isoclinal folds, and deformed Eocene chalk clast (Interval 150-905A-21H-2, 42-80 cm). 

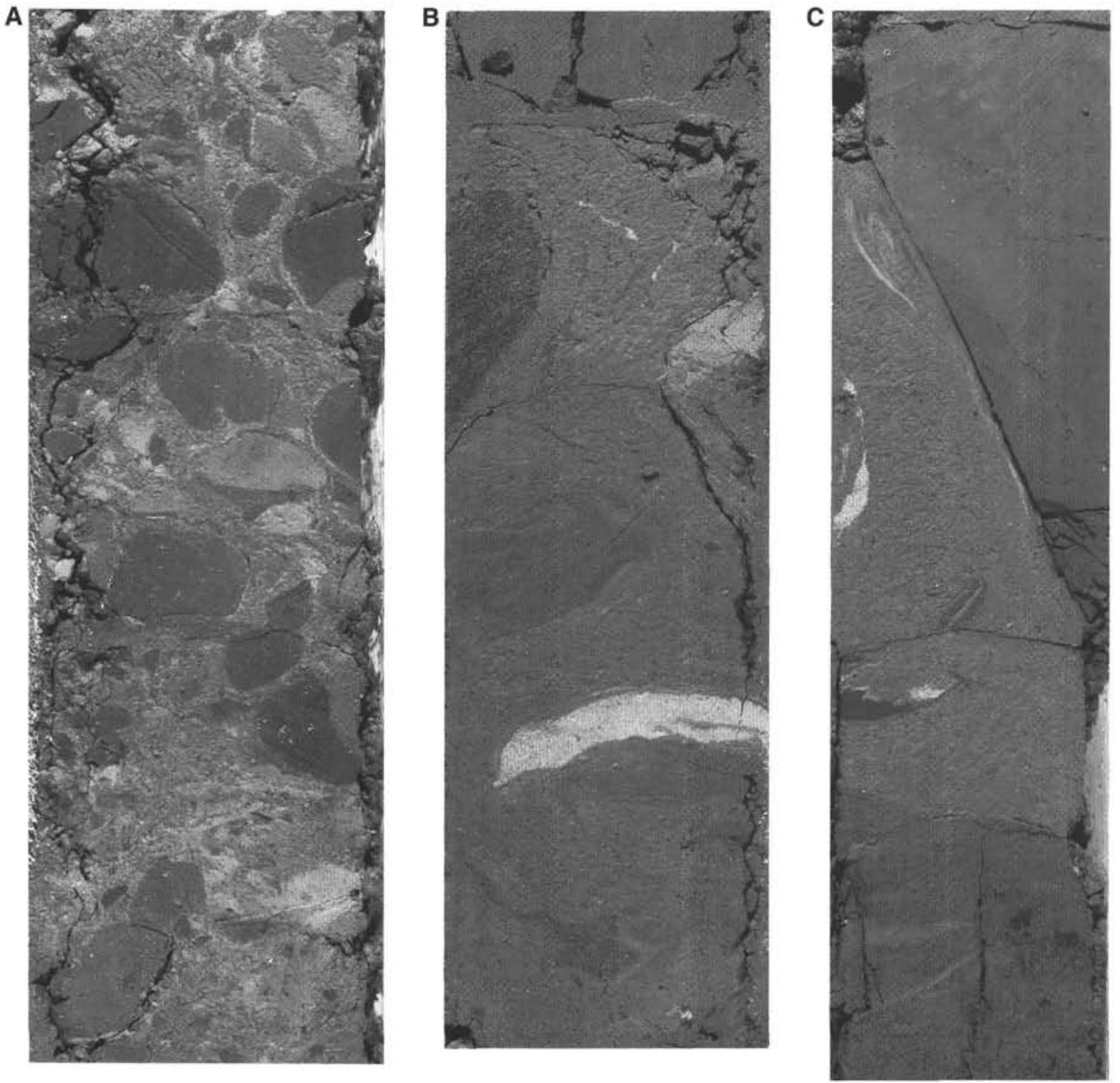

Figure 18. Examples of Facies 9: clast-supported conglomerates. A. Clasts of diverse ages (middle Eocene, Oligocene, and Miocene), sizes, lithologies, and degrees of induration (Interval 150-905A-73X-2, 100-120 cm). B. Abrupt contact between large clasts and underlying debris flow (Interval 150-905A-73X-6, $130-150 \mathrm{~cm}$ ). C. Steeply dipping faults and angular contacts are common (Interval 150-905A-74X-5, 35-60 cm). D. Deformed clasts within clasts indicate that some clasts have been involved in at least three episodes of deformation (note clast at $40-46 \mathrm{~cm}$ ) (Interval 150-905A-75X-3, 35-60 cm).

occurs in the upper Oligocene above an unconformity with the upper Eocene that corresponds to seismic reflection ol green-2 (681 mbsf).

In contrast to Site 903 , the correlation between mass-transport deposits of Facies 1-2 and sequence boundaries is not strong for the upper Miocene and Pleistocene. Unlike Site 903, sands of Facies 2 have a higher correlation to sequence boundaries at Site 902 from the upper Oligocene to the upper Miocene. Generally, Faciés 2 dominates the mass-transport deposits preserved at Site 902. Mass-transport deposits of Facies 1 and 2 represent only a small component $(\sim 11 \%)$ of the total sediment recovered at Site $902(736 \mathrm{~m})$. The remaining sediment is composed of predominantly hemipelagic sandy silts, silty clays, clayey silts, clays, and pelagic biosiliceous chalks.

\section{Site 904}

Mass-transport deposits of Facies 1 are rare beneath the lower middle slope at Site 904 (Figs. 3, 21; Table 3). A slump deposit (Facies 1) occurs at the base of the middle Pleistocene (96-98 mbsf) and correlates with seismic reflection $\mathrm{p} 4$. A bright green glauconite sandy mass flow with characteristics of Facies 2 and 1 occurs from 104 to $106 \mathrm{mbsf}$ and can be correlated to seismic reflection m0.7. Disseminated sands of Facies 2 are common in the Pleistocene and Miocene (Figs. 3, 21; Table 3). The major difference between Facies 2 at this location and the other upper slope sites is the abundance of glauconite at Site 904. Glauconite is especially abundant in the upper Oligocene to the middle Miocene and averages $20 \%$ to $40 \%$, and some intervals contain up to $80 \%$ glauconite.

Turbidites are rare to absent in the slope; however, a spectacular 4-m-thick unit of Facies 6 turbidites occurs in the middle Miocene at Site 904 . These turbidites are characterized by interbedded sand and silt layers. The sand laminae are a few centimeters thick and have sharp, scoured bases. The sands are composed of fine-grained, wellsorted quartz containing mica and abundant plant fragments. The silt layers are a few centimeters thick, greenish gray in color, and contain minor sand. The base of these turbidites correlates with seismic reflector $\mathrm{m} 2$ at $220 \mathrm{mbsf}$.

As at Site 902 the correlation between mass-transport deposits of Facies 1-2 and sequence boundaries is minor for the upper Miocene 


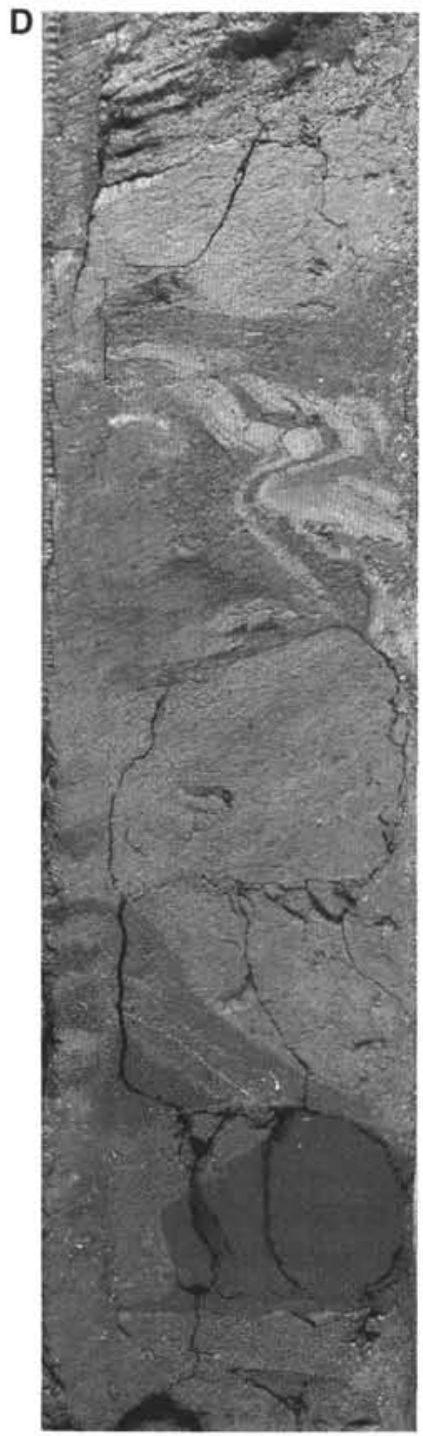

Figure 18 (continued).

and Pleistocene at Site 904. In contrast, all sequence boundaries are correlated to sands of Facies 2 and 6 from the upper Oligocene to the upper Miocene. Fewer seismic reflections were correlated to sequence boundaries at Site 904 than at Sites 903 and 902 . Mass-transport deposits constitute a minor component $(-15 \%)$ of the total sediment $(570 \mathrm{~m})$ recovered at 904 .

Generally, slumps and muddy debris flows of Facies 1 occur in the upper Miocene and Pleistocene, are best preserved at the upper paleoslope (Site 903), and they are least preserved at the middle paleoslope, Sites 902 and 904 . Sands of Facies 2 are most abundant from the upper Oligocene to the upper Miocene at Sites 902 and 904. Sandy debris flows of Facies 3 and 4 are unusual deposits that are only preserved at upper slope Site 903 .

In summary, correlation between mass-transport deposits and sequence boundaries is complex at the slope sites. In the Pleistocene and upper Miocene, mass-wasting deposits most frequently occur at sequence boundaries beneath the upper slope, but this correlation is less frequent downslope. In contrast, from the upper Oligocene to the upper Miocene the occurrence of sands of Facies 2 at sequence boundaries is greatest beneath the middle slope and is less frequent upslope. These observations suggest that there is a correlation between erosion and mass-transport deposition to sequence boundaries;

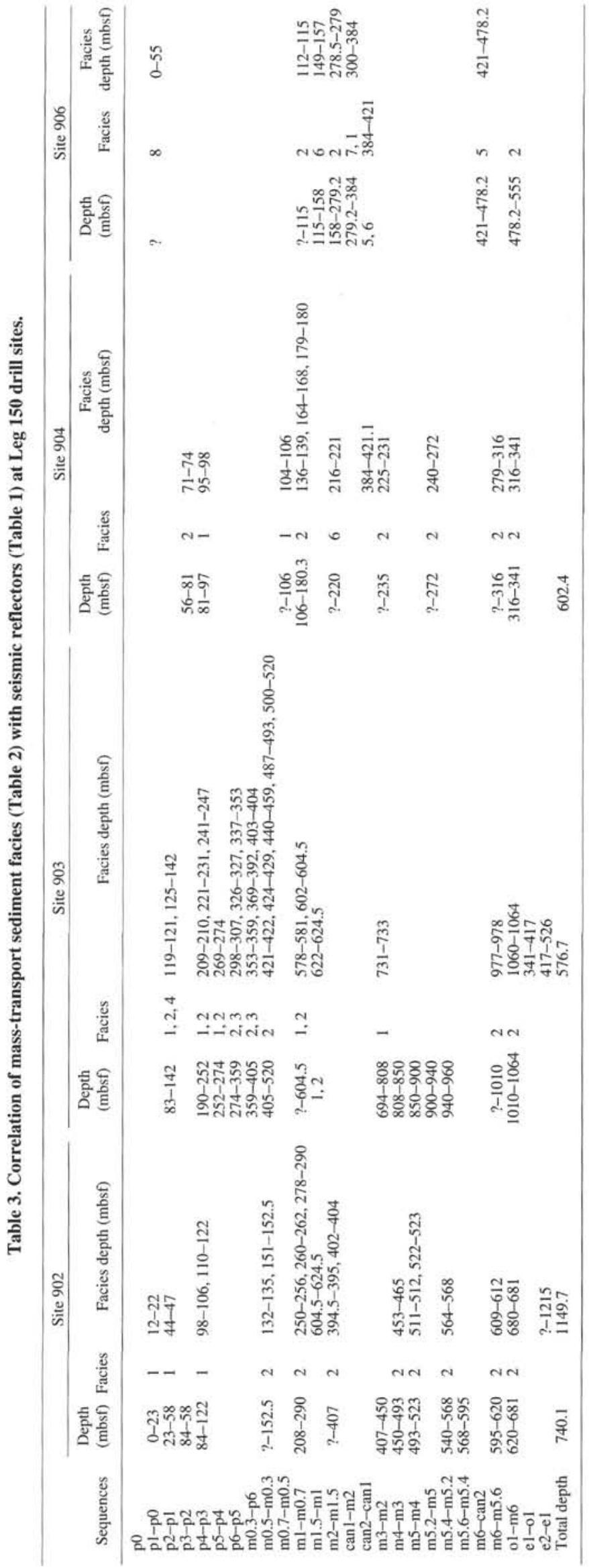




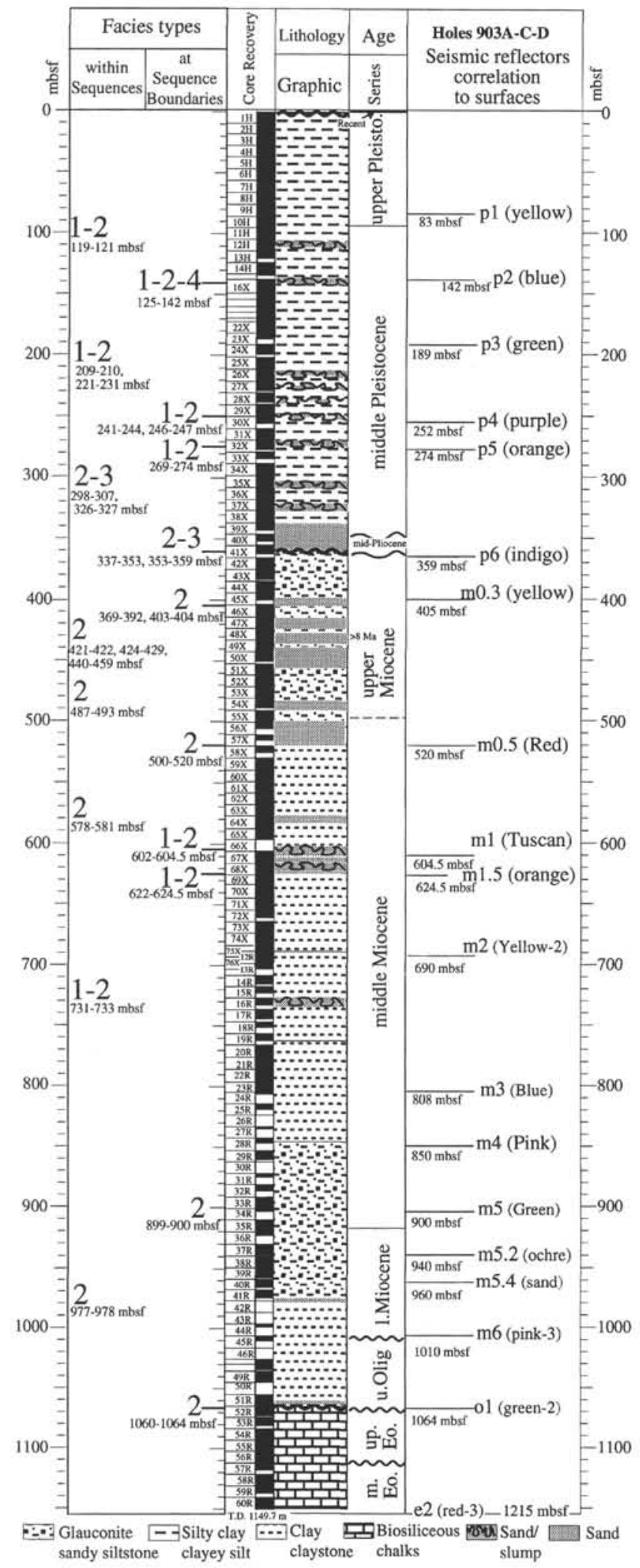

Figure 19. Site 903 lithology showing facies types at sequence boundaries and within sequences. Facies 1-4 frequently correlate to sequence boundaries in the upper Miocene and Pleistocene. However, Facies 1-3 also occur within sequences. The correlation between Facies 1-2 and sequence boundaries is minor from the upper Oligocene to the upper Miocene. Facies 1 predominates during the Pleistocene. In contrast, Facies 2 dominates from the upper Oligocene to the Pleistocene. however, preservation of mass-wasting deposits was influenced by the morphology and gradient of the existing paleoslope at the time of deformation. Steepening of the slope in response to sediment progradation in the late Miocene and Pleistocene may have led to masstransport further out into the continental rise (e.g., Site 905; see below). In contrast, the more gentle gradients of the Oligocene and lower and middle Miocene may have resulted in increased deposition and preservation of mass-transport deposits on the upper to middle paleoslope (Figs. 2, 3).

\section{RELATIONSHIP OF CANYON EXCAVATION AND FILLING TO BOUNDARIES AT SITE 906}

According to the Vail/Exxon conceptual sequence stratigraphic model, accelerated relative sea-level fall leads to exposure and intensified erosion of the shelf and slope to form a Type 1 sequence boundary (Vail et al., 1977, 1991; Haq et al., 1987; Posamentier et al., 1988; Posamentier and Vail, 1988; Vail, 1987; Van Wagoner et al., 1990). During these erosional episodes of sea-level lowering, submarine canyons are incised and act as conduits for sediment transport to the continental rise. Thus, drilling through the thalweg of a mature canyon, such as Berkeley (Pratson et al., 1994), and through a youthful canyon in its initial stages of development at Site 906, should permit better evaluation of the processes and timing of canyon formation and evolution. This may permit testing of the Vail/Exxon conceptual sealevel model.

The in situ lower Eocene to middle Miocene sediment (600-478.2 mbsf) at 906 is composed of pelagic biosiliceous chalks and hemipelagic siliciclastic sediment (Fig. 22). Seismic reflections ol (555.5 $\mathrm{mbsf})$ and $\mathrm{m} 6$ (478.2 mbsf) apparently correlate to sequence boundaries (Mountain, Miller, Blum, et al., 1994). The interval above seismic reflector ol ( $555.5 \mathrm{mbsf}$ ) appears to have been disturbed by drilling because the sediment contains pebbles of cemented sandstone, fractured zones of glauconitic silty sands, and drilling breccia. In addition, the age of the material is a mixture of early middle Eocene, early middle Oligocene, early Miocene, and late Pliocene. Seismic reflection $\mathrm{m} 6$ represents the deepest level of the Miocene slope canyon incision (Mountain, Miller, Blum, et al., 1994).

The stratal surface on which the initial slope failure occurred has been correlated to seismic reflection $\mathrm{m} 3$. Seismic reflector $\mathrm{m} 3$ was traced along Ew9009 Line 1027 to Line 1005 and correlated to other seismic lines along the shelf to a major Type 1 sequence boundary at $\sim 13.5 \mathrm{Ma}$ (Mountain, Miller, Blum, et al., 1994) and, thus, may correlate with a glacioeustatic lowering. The top of the canyon fill has been correlated to seismic reflection $\mathrm{m} 2$ and has an estimated age of 12.4 Ma. Thus, the entire episode of canyon excavation and infilling apparently occurred extremely rapidly $(\sim 1.1 \mathrm{Ma})$ within the time frame of a single third-order sea-level cycle (Mountain, Miller, Blum, et al., 1994).

The Miocene canyon-fill sequence is $199 \mathrm{~m}$ thick. Detailed studies of Facies 5 deposits indicate that the clast- and matrix-supported conglomerates and breccias have not been transported for long distances, and that they originated nearby, possibly from the canyon walls. Seismic reflection profiles across Site 906 indicate that during deposition of Facies 5, the canyon widened (Fig. 3). Six consecutive episodes of mass wasting are recorded in this interval, which is $57 \mathrm{~m}$ thick and extends between seismic reflections $\mathrm{m} 6$ and can 2 (canyon fill 2; Fig. 22). Microfaults, as well as clastic injections, suggest that the deposits were overpressured, possibly as a result of rapid loading of the sediment by subsequent mass-transport deposits. Therefore, Facies 5 is interpreted as the initial stages of the slope-canyon excavation. The base of this sequence is correlated to seismic reflection $\mathrm{m} 6$, which is the deepest level that was excavated during the canyon cutting episode. Seismic reflections can 2 and can 1 are local within the canyon and could not be correlated to other slope seismic reflections (Mountain, Miller, Blum, et al., 1994). 
Figure 20. Site 902 lithology showing facies types at sequence boundaries and within sequences. Some correlation occurs between Facies 1-2 and sequence boundaries in the upper Miocene and Pleistocene; however, Facies 1-2 also occur within sequences, and fewer seismic reflectors were correlated to the lithology than at Site 903. Correlation between Facies 2 and sequence boundaries occurs more frequently from the upper Oligocene to the upper Miocene.

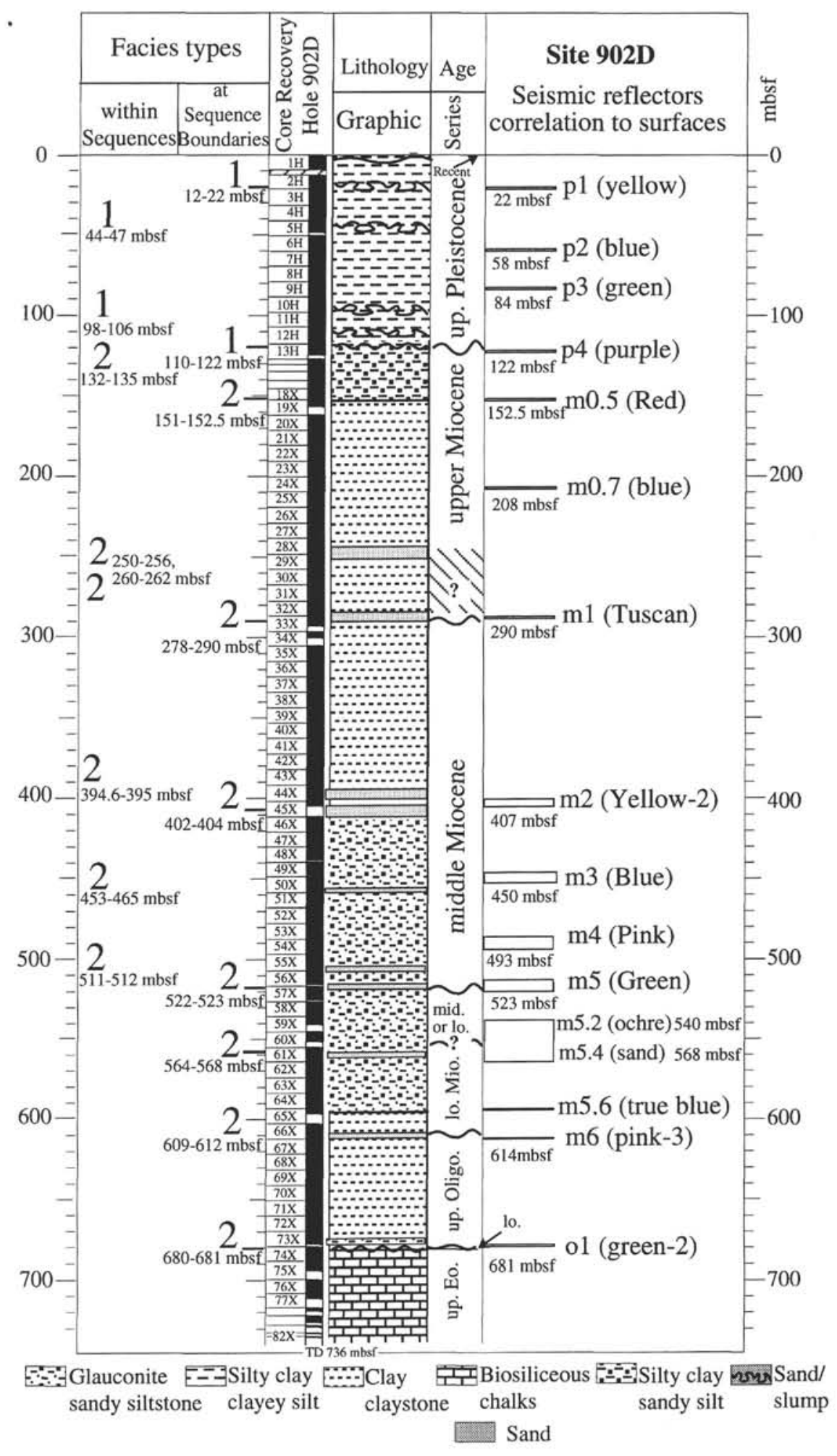

The overlying sequences, can 2 to can 1 (canyon fill 1 ) and can 1 to $\mathrm{m} 2$, are composed of laminated sands and silts of Facies 6 and laminated clays of Facies 7, respectively. These depositional events are interpreted as episodes of canyon filling, first by turbidity currents and then by pelagic and hemipelagic clays as the sediment source moved farther shoreward or the turbidity flows diminished in intensity. The thinning-upward and fining-upward unit of Facies 6 and the gradual disappearance of the siderite laminae toward the top of Facies 7 are consistent with the shoreward retreat of the source. Seismic mapping by Mountain et al. (this volume) showed that the head of the canyon was filled on the upper slope (5 km landward of Site 906) apparently by laminated clays of Facies 7 , which lapped out against the turbidites and breccias of Facies 5 and 6, respectively, $7 \mathrm{~km}$ seaward of Site 906. These stratal relations suggest that the head of the canyon filled first (Mountain et al., this volume).

This episode of Miocene Canyon incision and infilling lends support to the Vail-Exxon sequence stratigraphic conceptual model. A possible sequence of events is that canyon excavation, represented by 


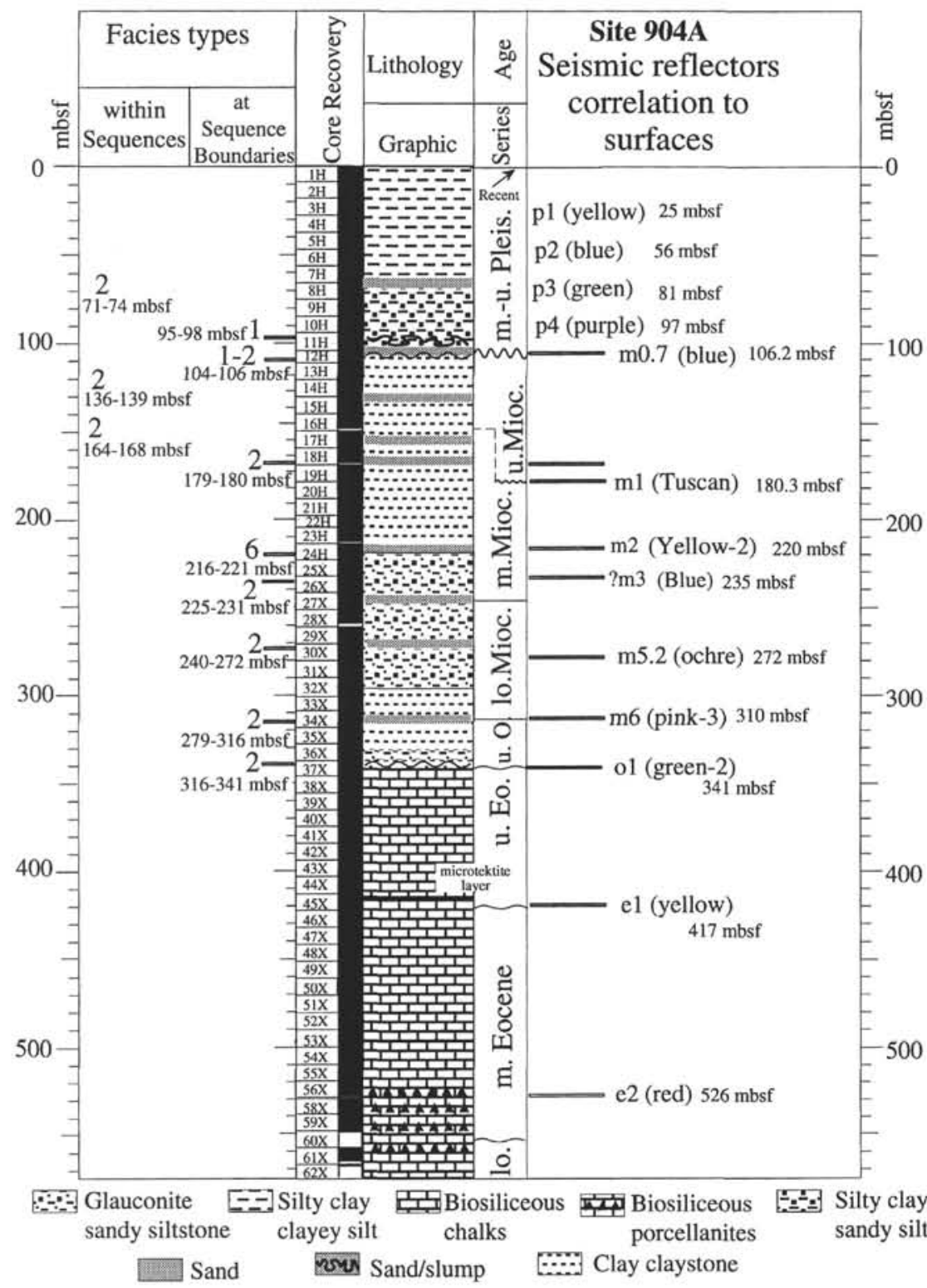

Figure 21. Site 904 lithology showing facies types at sequence boundaries and within sequences. Correlation between sequence boundaries and Facies 1-2 is minor for the upper Miocene and Pleistocene section. In contrast, Facies 2 and 6 correlate to all seismic reflectors identified from the upper Oligocene to the upper Miocene.
Facies 5, was accentuated as a result of a major relative sea-level lowering (lowstand systems tracts) at $\sim 13.5 \mathrm{Ma}$. Erosion and sediment transport to the slope and rise intensified as a result of sea-level lowering. Some of the material eroded during this episode of canyon excavation was preserved on the slope (Facies 5), while other was transported basinward. Middle Miocene slumps and debris flows recovered at Site 905 on the continental rise could have been derived from this or similar slope erosional/depositional episodes. Seismic profiles have not at this point been traced from Site 905 to Site 906 . Episodes of sediment deposition and canyon filling manifested by Facies 6 and 7 occurred across the slope and shelf as sea-level rose (transgressive systems tract), reached maximum highstand, and then began to fall (highstand systems tract). A new erosional unconformity (lowstand systems tracts), manifested by seismic reflector $\mathrm{m} 2$, with an estimated age of $12.4 \mathrm{Ma}$. developed at the top of the canyon fill.

Approximately $306 \mathrm{~m}$ of middle to upper Miocene hemipelagic siliciclastic sediment separates the buried Miocene slope canyon fill from the floor of modern Berkeley Canyon, which incises the present slope (Fig. 22). The sediment is predominantly in situ and the $\mathrm{m} 1$ and $\mathrm{ml} .5$ seismic reflections apparently correlate to sequence boundaries
(Mountain, Miller, Blum, et al., 1994). Gravity-flow processes occur in association with these upper Miocene seismic reflectors. An 8-m interval of sand laminae and beds of Facies 6 correlate to seismic reflection $\mathrm{ml} .5$ at $158 \mathrm{mbsf}$. Glauconitic sandy silts of Facies 2 correlate to seismic reflection $\mathrm{ml}$ ( $115 \mathrm{mbsf}$ ). The depositional character of this unit, which separates the Miocene canyon fill and Berkeley Canyon, indicates that the formation of Berkeley Canyon was not influenced by the Miocene canyon.

The topmost unit at Site 906 is $55 \mathrm{~m}$ thick and constitutes the fill of modern Berkeley Canyon. The sediment is Pleistocene in age and dominated by a series of muddy debris flows of Facies $8 \mathrm{a}$. The dominant fine-grained character of Facies $8 \mathrm{a}$ debris flows suggests that the terrestrial source for these deposits was not close by and that canyon infilling must have occurred during a sea-level highstand or as a result of the source moving farther north or south. The canyon fill sequence could not be correlated to the shelf or other slope sites (Mountain, Miller, Blum, et al., 1994).

At Site 906 there is a strong correlation between mass-transport deposits and sequence boundaries; however, only a few seismie reflections can be correlated to other slope sites and the shelf. The can- 
Figure 22. Site 906 lithology showing facies types at sequence boundaries and within sequences. Seismic reflection correlation to facies type was only possible in the intervals of hemipelagic deposition (in situ sediment) where a strong correlation occurs between Facies 2 and 6 and sequence boundaries. There is no correlation of seismic reflectors to sequence boundaries in the Berkeley and the middle Miocene canyon fills.

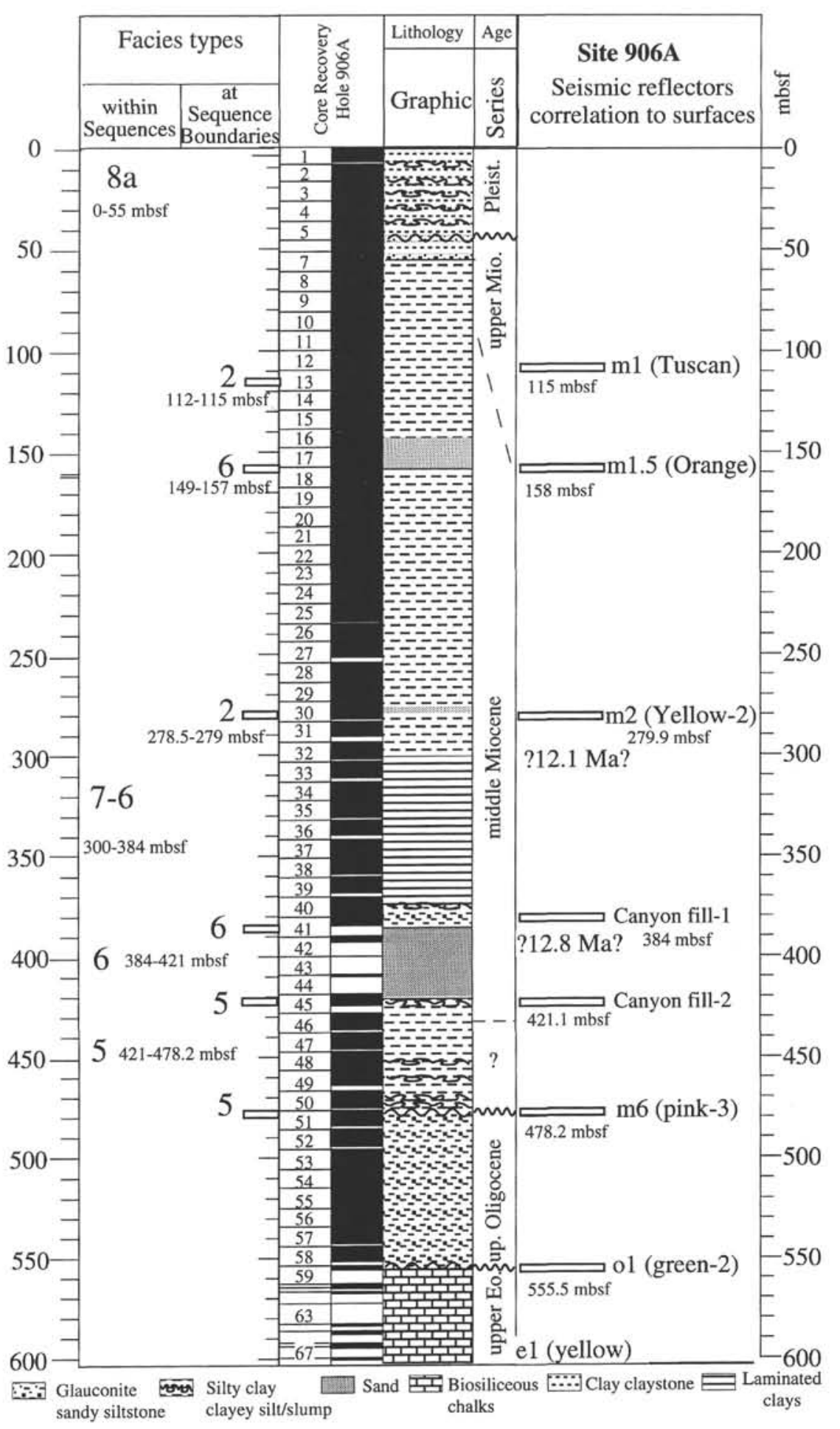

yon setting has the thickest preserved sections of mass-transport deposits of all slope sites ( $36 \%$ of the total sediment recovered at Site 906).

\section{ORIGIN OF DEPOSITS ON THE CONTINENTAL RISE IN THE VICINITY OF SITE 905}

The mass-transport deposits at Site 905 can be subdivided into a series of specific events based on the ages and compositions of the mud clasts contained in the deposits (Fig. 23). The oldest mass-transport unit is composed of middle Miocene slump deposits (Facies $8 \mathrm{~b}$ and 9) and comprises the interval 655-680 mbsf (Fig. 23B). This deposit apparently rests upon an erosional unconformity and possible sequence boundary marked by Reflector Yellow (Mountain, Miller, Blum, et al., 1994; Fig. 24). The clasts are of variable ages and mineralogy, which includes middle and late Eocene biosiliceous chalks, late Oligocene silty clays, and early and middle Miocene silty clays. Kaolinite (diagnostic of the Miocene and Oligocene) and smectite (characteristic of the Eocene) are the predominant clay minerals in 
these clasts (Fig. 23B). This mass-transport deposit apparently is the result of canyon cutting events upslope as evidenced by the variable ages and mineralogy of the clasts. The Eocene is exposed on the lower slope ( 1500 to $2200 \mathrm{~m}$ ), where canyons have deeply excavated into biosiliceous chalks and porcellanites. This mass-transport deposit at 655-680 mbsf, as well as any other continental rise mass-wasting deposits which contain Eocene clasts, must have moved downslope through canyons or the lower slope where they entrained exposed Eocene material.

A middle Miocene slump/debris-flow deposit composed of Facies 1 occurs from 618 to $620 \mathrm{mbsf}$. The clasts in this deposit are uniformly middle Miocene in age (Fig. 25). In contrast to the Facies $8 \mathrm{~b}$ and 9 deposit at 655-680 mbsf (above), this deposit is interpreted to have resulted from localized slope failure and detachment in an intercanyon area of the slope because of the uniform age of the clasts and matrix. This deposit is overlain by two more slump/debris flow deposits of late Miocene age (553-567 mbsf and 568-573 mbsf) that are also composed of Facies 1 and contain clasts of late Miocene age. These deposits are also interpreted as localized slope detachments from intercanyon areas because of the uniform age of the clasts and matrix. Reflector Merlin, a major regional seismic reflection, occurs between the top of the middle Miocene deposit and the lower portion of the oldest upper Miocene deposit (Mountain, Miller, Blum, et al., 1994; Fig. 24). The clasts of all three of these deposits are characterized by abundant kaolinite, which is the characteristic clay of the Miocene. This clay mineralogy reinforces the interpretation that these deposits are intercanyon slope detachments that have not been transported through canyons. Mass-transport deposits derived and transported through canyons would have entrained clasts of diverse lithology such as the Eocene biosiliceous chalks contained in the mass-transport deposit from 655 to $680 \mathrm{mbsf}$ described above.

The Pleistocene section at Site 905 is composed mainly of masstransport deposits of Facies $8 \mathrm{~b}$ and 1 (Fig. 24). These deposits are characterized by abundant chlorite, whereas chlorite is absent from the Miocene deposits below (Fig. 23). The two lowermost masstransport units ( $80-98$ and 106-215 mbsf) are characterized by muddy slumps and debris flows of Facies $8 \mathrm{~b}$ and contain clasts of variable ages, including middle and late Eocene, Pliocene, and Pleistocene (Fig. 23A). The interval from 106 to 215 mbsf may actually contain multiple events because some of the mass-transport deposits are separated by a 6-m-thick interval of silty clay and by a 5-m-thick sand layer. The interval from 80 to $98 \mathrm{mbsf}$ is separated from the deposits above and below by an 8 -m-thick sand interval and an 8 -m-thick silty clay interval, respectively. These Pleistocene slump/debris-flow deposits are interpreted as canyon-cutting events because of the multiple ages and variable lithology of the clasts within them. The base of this Pleistocene sequence of deposits coincides with the prominent regional Reflector Brown (Mountain, Miller, Blum, et al., 1994; Fig. 24).

In contrast, the interval from 45 to $72 \mathrm{mbsf}$ contains a slump/debris-flow deposit composed of Facies 1, which contains clasts of Pliocene and possibly upper Miocene age. The clasts contain chlorite and kaolinite clays, which are characteristic of the Pliocene and Miocene, respectively. This deposit is separated from the mass-transport deposits above and below by a 2.5 -m-thick silty clay interval and an 8-m-thick sand layer, respectively. This deposit is interpreted as a localized intercanyon slope detachment because of the uniform lithology and age of the clasts and the matrix (upper Miocene to lower Pleistocene).

The uppermost slump/debris-flow deposit in the Pleistocene section occurs from 20 to 42 mbsf and is composed of Facies $8 \mathrm{~b}$ (Fig. 23A). Clast ages include middle Eocene, Pliocene, and Pleistocene. The diverse mineralogy of the clasts that contain kaolinite and chlorite clays, and biosiliceous chalks, is also consistent with Facies $8 \mathrm{~b}$. This deposit is interpreted to have originated as a result of canyoncutting event (s) because of the mixture of ages and mineralogy associated with the clasts.
The uppermost $20 \mathrm{~m}$ of sediment ( $0-20 \mathrm{mbsf})$ were not cored because of safety concerns; however, $3.5-\mathrm{kHz}$ echograms and watergun seismic profiles $(<150 \mathrm{~Hz})$ across Site 905 indicated that masstransport deposits are present in the top $20 \mathrm{~m}$ (see fig. 5, "Site 905" chapter in Mountain, Miller, Blum, et al., 1994). In addition, a television and sidescan sonar survey conducted within a $100-\mathrm{m}$ radius of the drilling site showed large, semirounded boulders or blocks at least $3 \mathrm{~m}$ in diameter partially buried in the seafloor. Even larger blocks up to $10 \mathrm{~m}$ in diameter have been previously observed in sidescan sonar images in the vicinity of Site 905 (Farre and Ryan, 1987). In these instances, the blocks are deposited at the end of long downslope-trending lineations that can be traced to the lower slope. Talus blocks of up to $10 \mathrm{~m}$ in diameter commonly occur scattered in the lower slope canyon floors (McHugh et al., 1993). The linear tracks that head on the lower continental slope suggest that the blocks were transported from the lower slope canyons to the continental rise as part of downslope mass-wasting events.

Benthic foraminifer assemblages recovered from clasts in the slumps and debris flows of Site 905 indicate that these mass-wasting events could have been initiated anywhere between $<200$ and $2000 \mathrm{~m}$ water depths. Gradients on the modern continental slope and rise are approximately $4^{\circ}$ and $1^{\circ}$, respectively, and may have been even lower during the Miocene. Transport distances from the upper paleoslope to Site 905 on the continental rise were probably a maximum of $75 \mathrm{~km}$ and a minimum of $35 \mathrm{~km}$ from the base of the paleoslope.

Deformed clasts within clasts and other deformation features suggest that some of these mass-transport deposits record at least three separate episodes of transport and deformation. This suggests entrainment of relict slumps and debris flows during subsequent masswasting events. This is not surprising because sampling of blocks that commonly lie scattered on the floors and walls of the New Jersey continental slope canyons revealed that the blocks are relic Miocene mass-transport deposits (W.B.F. Ryan, K.G. Miller, and C.M. McHugh, unpubl. data from Alvin dives). Such deposits could have easily been entrained by subsequent mass-wasting events. Benthic foraminifer assemblages also indicate that some of these deposits were transported more than once.

\section{RELATIVE CONTRIBUTION OF DOWNSLOPE SEDIMENT TRANSPORT TO THE DEVELOPMENT OF THE CONTINENTAL RISE}

Approximately $30 \%(260 \mathrm{~m})$ of the $910 \mathrm{~m}$ of sediment recovered at Site 905 constitute mass-transport deposits of Facies 1, 8b, and 9 (Fig. 24). The most extensive transport of mass-wasting deposits to the upper rise occurred during the lower Pleistocene, where these deposits are $215 \mathrm{~m}$ thick. The rest of the sediment appears to have been deposited by normal hemipelagic sedimentation. Sedimentation rates of $5.5 \mathrm{~cm} / \mathrm{k}$.y. were calculated for the $322-\mathrm{m}$-thick, lower Pleistocene to upper Miocene interval. Sedimentation rates for middle Miocene sediment $(230 \mathrm{~m}$ thick) were calculated at $9.2 \mathrm{~cm} / \mathrm{k} . \mathrm{y}$. (Mountain, Miller, Blum, et al., 1994; Fig. 24). However, biostratigraphic gaps that could signify episodes of erosion have not been ruled out for the apparently undisturbed middle Miocene interval (Mountain, Miller, Blum, et al., 1994).

During the middle Miocene approximately $30 \mathrm{~m}$ of mass-wasting deposits were deposited on the rise around Site 905. As explained above, the age and composition of the clasts contained in these masstransport deposits indicate episodes of deep canyon erosion or slope excavation (Fig. 3). A possible source for these deposits is the Miocene slope canyon drilled at Site 906 and other buried canyons of the same age observed beneath the modern outer shelf (Mountain et al., this volume). The matrix of the continental rise mass-transport deposits corresponds in age $(\sim 13.5 \mathrm{Ma})$ to the age of initiation of slope canyon excavation at Site 906. Channel excavation also occurred during the middle Miocene on the upper continental rise (Mountain, 
A

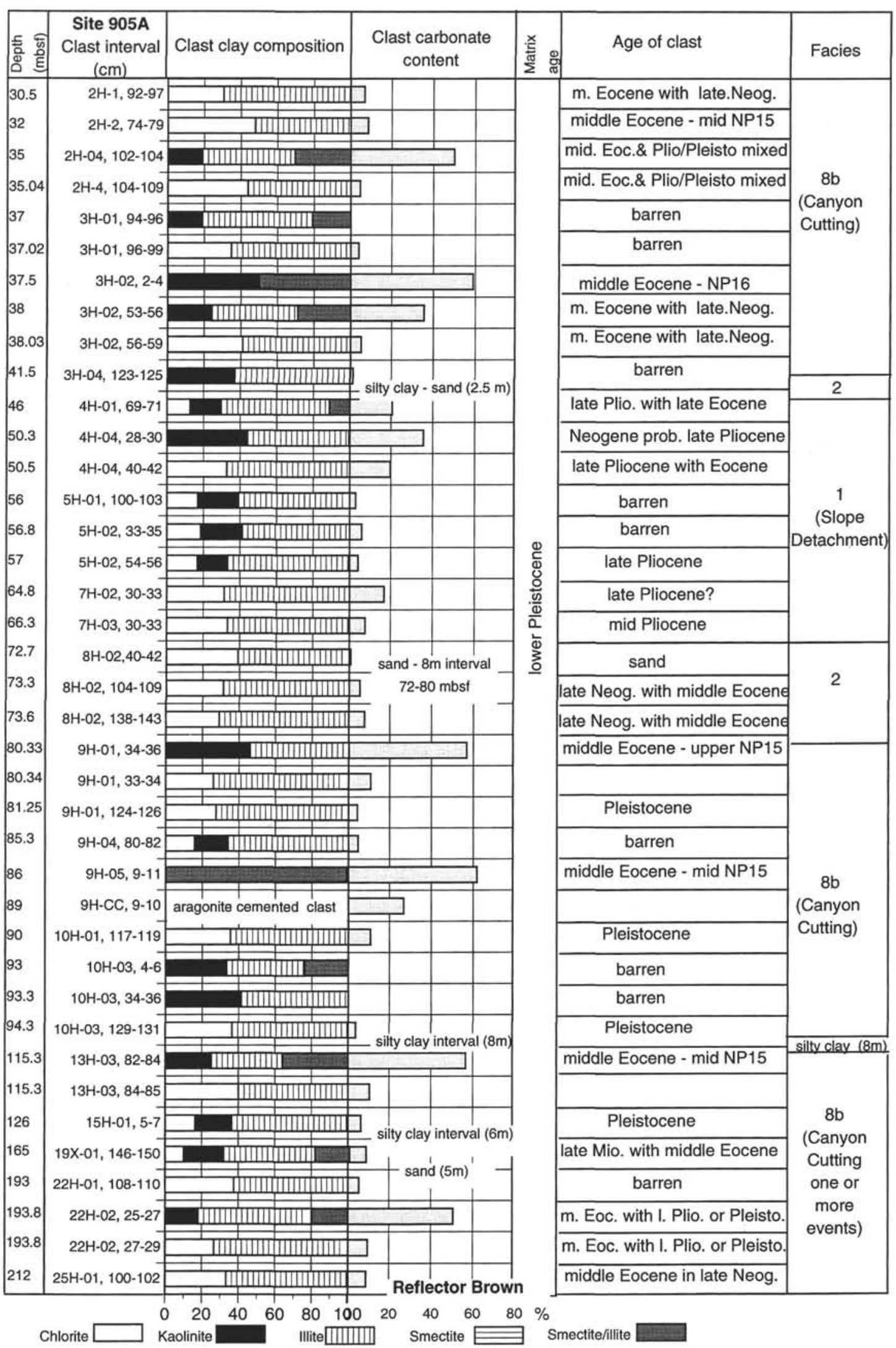

Figure 23. Analyses of clasts from Site 905 mass-transport deposits showing depth below the seafloor of sample (mbsf), clast interval (cm), clast clay-mineral composition, clast carbonate content, age of clast, age of the matrix, and facies type. A. Clasts from lower Pleistocene debris flows and slides composed of Facies 1, 2, and 8b. Reflector Brown correlates with the base of the lower Pleistocene mass-transport deposits. B. Clasts from clast-supported conglomerates of Facies 9 of Miocene age. Reflector Yellow occurs at the base of the middle Miocene deposits. Reflector Merlin is correlated to the base of an upper Miocene deposits. 
B

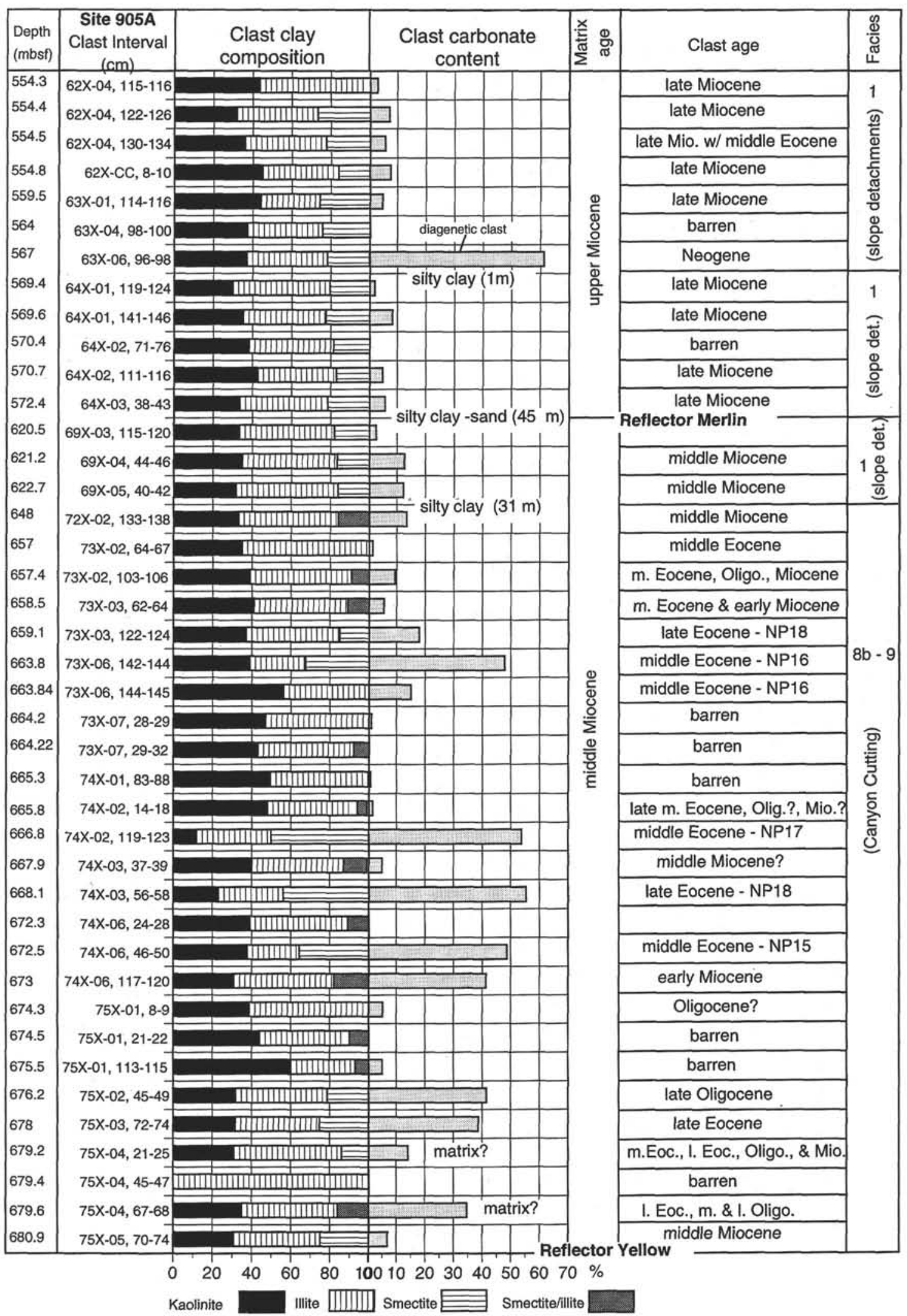

Figure 23 (continued). 


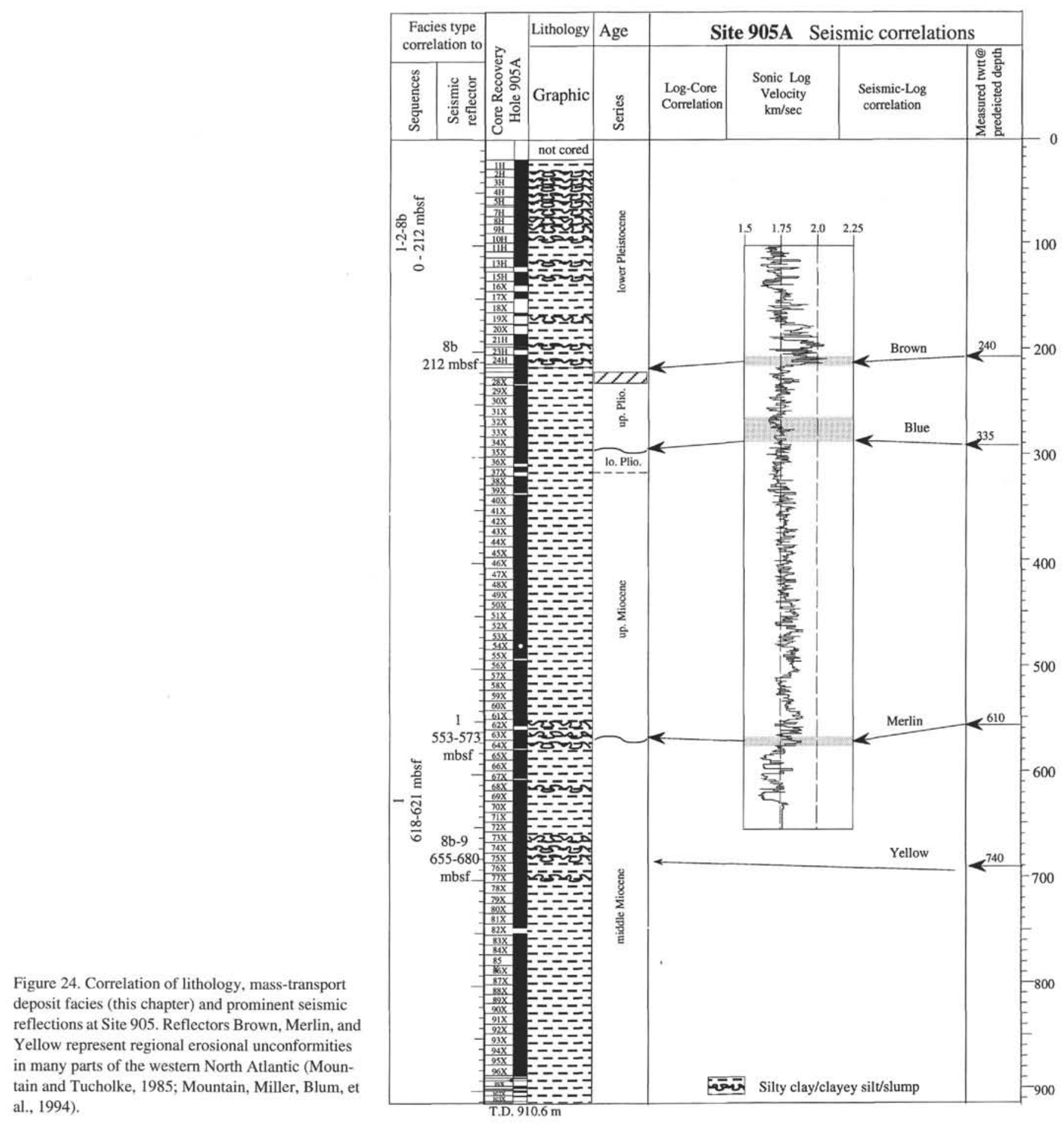

1987). During this episode, channels were cut into Eocene sediment, and slumps and debris flows derived from these events also possibly contributed to the growth of the rise near Site 905. The 30-m-thick interval of mass-transport deposits suggests that the relative contribution of the middle Miocene episode of slope canyon cutting and channel incision to the upper continental rise (in the vicinity of Site 905) was not very significant.

Significant slope erosion and downslope transport from the continental slope to the rise occurred near the middle/late Miocene boundary, when numerous canyons were excavated (Mountain, 1987).
These events deposited a 5-m-thick, middle to late Miocene and a 13$\mathrm{m}$-thick, upper Miocene series of slumps and debris flows in the vicinity of Site 905 . These deposits apparently originated from localized failures of the continental slope. An unconformity that correlates with Reflector Merlin occurs between the middle and upper Miocene mass-wasting deposits and represents an erosional unconformity in many parts of the western North Atlantic (Mountain and Tucholke, 1985). This indicates that the middle and upper Miocene episodes of mass wasting were not isolated events, but rather were common occurrences for the western North Atlantic. However, the $18 \mathrm{~m}$ of trans- 


\section{A}

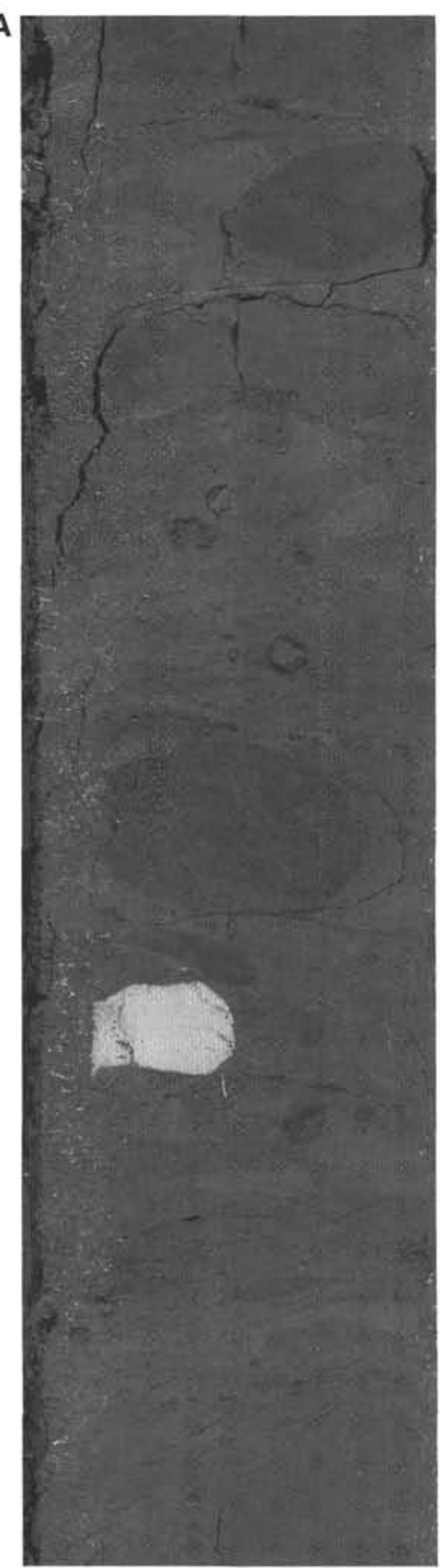

B

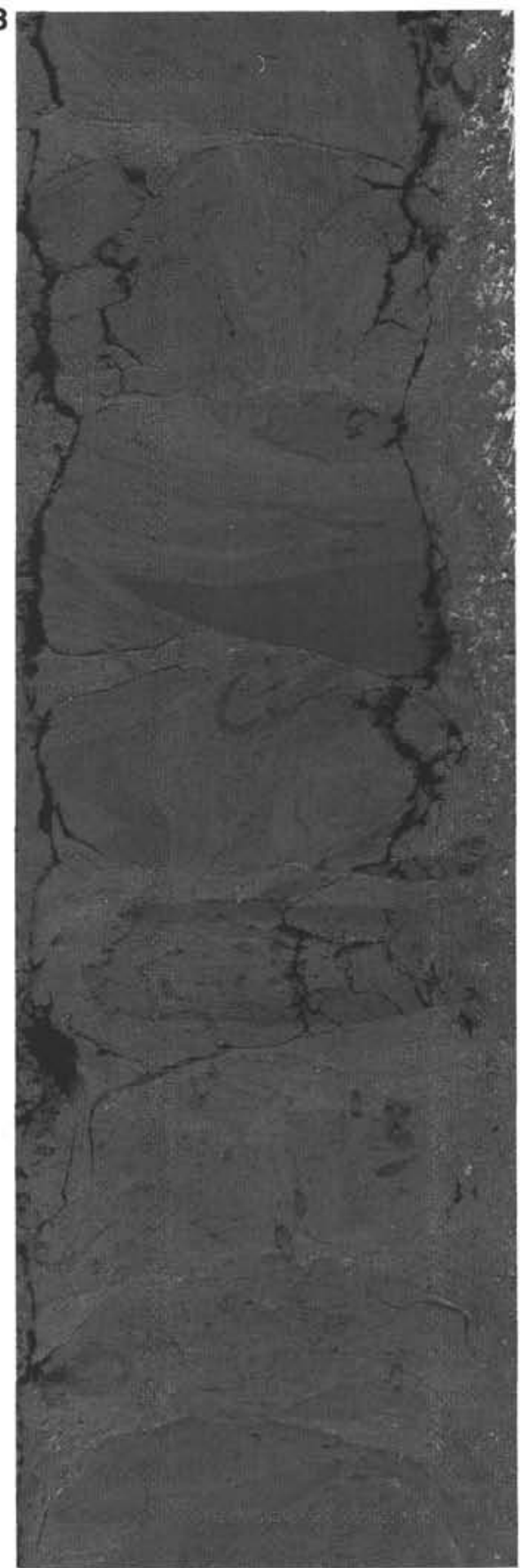

Figure 25. Upper Miocene slope detachments of Facies 1 on the continental rise at Site 905. A. Muddy debris flow with subrounded mud clasts and a diagenetic clast composed of dolomite (Interval 150$905 \mathrm{~A}-63 \mathrm{X}-6,82-106 \mathrm{~cm})$. B. Muddy debris flow with subrounded clasts and soft sediment deformation features (Interval 150-905A-64X-1, 110-130 $\mathrm{cm})$. ported material recovered at Site 905 suggests that these deposits did not contribute significantly to the growth of the upper rise, at least near Site 905.

Pleistocene mass-transport deposits on the continental rise are $\sim 215 \mathrm{~m}$ thick and document episodes of canyon excavation, as well as slope failures. Vassallo et al. (1983) identified a "blocky" sediment slide complex on $3.5-\mathrm{kHz}$ echograms within the general region of Sites 902, 904, 905, and 906. Deformed sediment of Facies 1, 2, 8a, and 8 b occur near the surface at Sites 902,905 , and 906 and may be the source for the "blocky" acoustic character of this slide complex. In more recent studies, the acoustic backscatter of GLORIA imagery from the New Jersey continental rise reveals high-backscatter pathways that continue from submarine-canyon mouths downslope toward the continental rise (Schlee and Robb, 1991). Piston coring and deep-towed sidescan-sonar ground-truthing studies offshore New Jersey reveal that sediment with clasts (mud balls and other more indurated clasts) has more internal volume scatter of sound energy than other sediments (i.e., scattering is more influenced by the geometry of the clasts [Ryan, 1991]). Therefore, these high backscatter trails on the GLORIA images most likely mark the path of mass-transport deposits from canyon mouths to the continental rise. These patterns show that the major canyon systems which have contributed sediment to the continental rise in the vicinity of Site 905 are Carteret, Berkeley, and Tom Canyons. According to Schlee and Robb (1991) sediment is distributed to the continental rise through a dendritic system of channels or "gather area." These channels head from the slope canyons and extend to the continental rise, where they converge into Wilmington Valley, a single major channel. Site 905 is within the 
"Baltimore-Toms gather area" (Twichell, 1986; Schlee and Robb, 1991).

Reflector Brown, which coincides with the base of the Pleistocene slumps and debris flows, has been traced for tens of kilometers to the Hudson Canyon levee (Mountain, Miller, Blum, et al., 1994). The chaotic character of the overlying seismic unit can also be traced along strike to the Hudson Canyon levee (Mountain, Miller, Blum, et al., 1994). This suggests that slope failures and canyon excavation events were prevalent along the western Atlantic continental margin during this Pleistocene interval. Widespread erosion and downslope transport of sediment during the Pleistocene appears to have been much more extensive and contributed more to the growth of the upper continental rise than Miocene episodes of mass wasting.

\section{SUMMARY}

The observed occurrences of mass-transport deposits at the bases of sequence boundaries on the continental slope and on the continental rise suggest that extensive mass wasting is associated with the formation of major erosional unconformities and that large volumes of sediment are transported into the basin during these erosional events, which apparently correlate with sea-level lowerings (i.e., lowstand systems tracts). However, the relationship of mass-transport deposits to sequence boundaries is complex. In the Pleistocene and upper Miocene sections, mass-wasting deposits most frequently correlate with sequence boundaries beneath their respective upper paleoslopes, but this correlation is less frequent downslope. In contrast, from the upper Oligocene to the upper Miocene, the occurrence of mass-transport deposits at sequence boundaries is greatest beneath the respective middle paleoslopes, but is less frequent upslope. These observations suggest a correlation between slope erosion leading to generation of mass-transport deposits and sequence boundaries. However, preservation of mass-wasting deposits was significantly influenced by the morphology and gradient of the existing paleoslope. Steepening of the slope in response to more rapid seaward sediment progradation during the late Miocene to the Pleistocene may have led to increased sediment failure and movement of failed sediment to the continental rise. In contrast, the more gentle gradients of the Oligocene to middle Miocene paleoslopes may have resulted on increased deposition and preservation of mass-transport deposits on the more proximal upper- to middle paleoslopes. The correlation between masstransport deposits and sequence boundaries is further complicated because mass-transport deposits occur within sequences especially in the upper Miocene and Pleistocene.

Approximately $11 \%$ to $15 \%$ of the total sediment recovered at each slope site (902-904) is mass-transport deposits. The rest of the sediment is composed of hemipelagic silts and clays and pelagic biosiliceous chalks. Mass-transport deposits are more abundant in the canyon setting at Site 906 , where such deposits constitute $~ 36 \%$ of the recovered sediment section.

An extremely rapid ( 1 m.y.) episode of canyon excavation and infilling during a single third-order sea-level cycle $(\sim 13.5-12.4 \mathrm{Ma})$ occurred during the middle Miocene at Site 906. The causal mechanism for canyon incision and subsequent infilling can be linked to a sea-level fall (Type 1 unconformity) and rise, and appears to support the Vail-Exxon conceptual sea-level model.

Downslope transport has volumetrically ( $\sim 30 \%$ of the total sediment recovered) contributed to the growth of the continental rise. Sediment transport to the upper rise was much more extensive during the Pleistocene than during the middle and upper Miocene. Slides and debris flows were transported from the slope to the continental rise for distances of at least $75 \mathrm{~km}$. Mass-transport deposits of Facies 8b and 9 reveal numerous canyon-incision episodes. During these excavation events, large blocks were entrainzd and transported from the lower slope canyons to the continental rise. Mass-transport deposits of the continental rise indicate that canyon-cutting events were com- mon during the early Pleistocene. Slope detachments have contributed sediment to the continental rise during the Miocene and Pleistocene. At least three episodes of mass-transport have been documented in middle Miocene slump deposits (Facies 9) on the continental rise.

\section{ACKNOWLEDGMENTS}

We are grateful to G.S. Mountain, K.G. Miller; P. Blum, and the Leg 150 Shipboard Scientific Party for making this study possible. We thank the captain, officers, and the crew of the JOIDES Resolution for their efforts during the collection of the data. We thank William B.F. Ryan, Pierre Biscaye, and Mohammed El Tabak for their contributions to this study. Reviews by Robert Jacobi and Dave Twichell contributed to the improvement of the manuscript. We thank Dee Breger from Lamont-Doherty Earth Observatory (LDEO) for her support in the SEM/EDX analyses, Pat Malone (LDEO) for carbonate analyses, Lenny Canone from Queens College (QC) for the preparation of the petrographic thin sections, and John Walsh (QC) for his support in the X-ray diffraction analyses. This study was supported by JOI/USSAC. This is a Lamont-Doherty Earth Observatory contribution 5451.

\section{REFERENCES}

Biscaye, P.E., 1965. Mineralogy and sedimentation of recent deep-sea clays in the Atlantic Ocean and adjacent seas and oceans. Geol. Soc. Am. Bull., $76: 803-832$.

Bouma, A.H., 1962. Sedimentology of Some Flysch Deposits: A Graphic Approach to Facies Interpretation: Amsterdam (Elsevier).

Christie-Blick, N., 1991. Onlap, offlap, and the origin of unconformitybounded depositional sequences. Mar. Geol., 97:35-56.

Christic-Blick, N., Mountain, G.S., and Miller, K.G., 1990. Stratigraphic and seismic stratigraphic record of sea-level change. In Sea-level Change: Washington (National Academy Press), 116-140.

Damuth, J.E., and Embley, R.W., 1981. Mass-transport processes on the Amazon Cone: western equatorial Atlantic. AAPG Bull., 65:629-643.

Dingle, R.V., 1977. The anatomy of a large submarine slump on a sheared continental margin (SE Africa). J. Geol. Soc. London, 134:293-310.

Embley, R.W., 1980. The role of mass transport in the distribution and character of deep-ocean sediments with special reference to the North Atlantic. Mar. Geol., 38:23-50.

Embley, R.W., and Jacobi, R.D., 1977. Distribution of large sediment slides and slumps on Atlantic continental margins. Mar. Geotechnol., 2:205228 .

1986. Mass wasting in the western North Atlantic. In Vogt, P.R., and Tucholke, B.E. (Eds.), The Western North Atlantic Region. Geol. Soc. Am., Geol. of North Am. Ser., M:479-490.

Farre, J.A., McGregor, B.A., Ryan, W.B.F., and Robb, J.M., 1983. Breaching the shelfbreak: passage from youthful to mature phase in submarine canyon evolution. In Stanley, D.J., and Moore, G.T. (Eds.), The Shelfbreak: Critical Interface on Continental Margins. Spec. Publ.-Soc. Econ. Paleontol. Mineral., 33:25-39.

Farre, J.A., and Ryan, W.B.F., 1987. Surficial geology of the continental margin offshore New Jersey in the vicinity of Deep Sea Drilling Project Sites 612 and 613. In Poag, C.W., Watts, A.B., et al., Init. Repts. DSDP, 95: Washington (U.S. Govt. Printing Office), 725-759.

Fisher, R.V., 1971. Features of coarse-grained, high-concentration fluids and their deposits, J. Sediment. Petrol., 41:916-927.

Gawthorpe, R.L., and Clemmey, H., 1985. Geometry of submarine slides in the Bowland Basin (Dinantian) and their relation to debris flows. J. Geol. Soc. London, 142:555-565.

Greenlee, S.M., Devlin, W.J., Miller, K.G., Mountain, G.S., and Flemings, P.B., 1992. Integrated sequence stratigraphy of Neogene deposits, New Jersey continental shelf and slope: comparison with the Exxon model. Geol. Soc. Am. Bull., 104:1403-1411.

Greenlee, S.M., Schroeder, F.W., and Vail, P.R., 1988. Seismic stratigraphic and geohistory analysis of Tertiary strata from the continental shelf off New Jersey: calculation of eustatic fluctuations from stratigraphic data. In Sheridan, R.E., and Grow, J.A. (Eds.), The Atlantic Continental Margin. Geol. Soc. Am., Geol. of North Am. Ser., 437-444. 
Griffin, J.J., Windom, H., and Goldberg, E.D., 1968. The distribution of clay minerals in the World Ocean. Deep-Sea Res. Part A, 15:433-459.

Hampton, M.A., 1972. The role of subaqueous debris flow in generating turbidity currents. J. Sediment. Petrol., 42:775-793.

Haq, B.U., Hardenbol, J., and Vail, P.R., 1987. Chronology of fluctuating sea levels since the Triassic. Science, 235:1156-1167.

Helwig, J., 1970. Slump folds and early structures, northeastern Newfoundland Appalachians. J. Geol., 78:172-187.

Jacobi, R.D., 1976. Sediment slides on the northwestern continental margin of Africa. Mar. Geol., 22:157-173.

Jansa, L.F., Enos, P., Tucholke, B.E., Gradstein, F.M., and Sheridan, R.E., 1979. Mesozoic-Cenozoic sedimentary formations of the North American Basin, western North Atlantic. In Talwani, M., Hay, W., and Ryan, W.B.F. (Eds.) Deep Drilling Results in the Atlantic Ocean: Continental Margins and Paleoenvironment. Am. Geophys. Union, Maurice Ewing Ser., 3:1-57.

Johnson, A.M., 1970. Physical Processes in Geology: San Francisco (Freeman, Cooper and Co.).

Kastner, M., 1981. Authigenic silicates in deep sea sediments: formation and diagenesis. In Emiliani, C. (Ed.), The Sea (Vol. 7): The Oceanic Lithosphere: New York (Wiley), 915-980.

Laine, E.P., Damuth, J.E., and Jacobi, R.D., 1986. Surficial sedimentary processes revealed by echo-character mapping in the western North Atlantic. In Vogt, P.R., and Tucholke, B.E. (Eds.), The Western North Atlantic Region. Geol. Soc. Am., Geol. of North Am. Ser., M:427-436.

Lancelot, Y., Hathaway, J.C., and Hollister, C.D., 1972. Lithology of sediments from the western from the western North Atlantic. In Hollister, C.D., Ewing, J.I., et al., Init. Repts. DSDP, 11: Washington (U.S. Govt. Printing Office): 901-949.

Malahoff, A., Embley, R.W., Perry, R., and Fefe, C., 1980. Submarine masswasting of sediments on the continental slope and upper rise south of Baltimore Canyon. Earth Planet. Sci. Lett., 49:1-7.

Margins Steering Committee Members, 1993. MARGINS: toward a Novel Science Plan. Eos, 74:570-572

Martinsen, O.J., 1989. Styles of soft-sediment deformation on a Namurian (Carboniferous) delta slope, Western Irish Namurian Basin, Ireland. In Whateley, K.G., and Pickering, K.T. (Eds.), Deltas: Sites and Traps for Fossil Fuels. Geol. Soc. Spec. Publ. London, 41:167-177.

McGregor, B.A., and Bennett, R.H., 1977. Continental slope instability northwest of Wilmington Canyon. AAPG Bull., 61:918-928.

, 1979. Mass movement of sediment on the continental slope and rise seaward of Baltimore Canyon Trough. Mar. Geol., 33:163-174.

, 1981. Sediment failure and sedimentary framework of the Wilmington geotechnical corridor, US Atlantic continental margin. Sediment. Geol., 30:213-234.

McHugh, C.M., Ryan, W.B.F., and Hecker, B., 1992. Contemporary sedimentary processes in the Monterey Canyon fan system. Mar. Geol, 107:35-50.

McHugh, C.M., Ryan, W.B.F., and Schreiber, B.C., 1993. The role of diagenesis in exfoliation of submarine canyons. AAPG Bull., 77:145172

McHugh, C.M., Ryan, W.B.F., Schreiber, B.C., Pratson, L., Pirmez, C., and Miller, K.G., 1991. U.S. east coast continental slope fractures and neptunian dikes, Eos, 72:164

Middleton, G.V., and Hampton, M.A., 1973. Sediment gravity flows: mechanics of flow and deposition. In Middleton, G.V., and Bouma, A.H (Eds.), Turbidites and Deep Water Sedimentation. Short Course Notes, Soc. Econ. Paleontol. Mineral., Pacific. Sect., 1-38.

Miller, K.G., Fairbanks, R.G., and Mountain, G.S., 1987. Tertiary oxygen isotope synthesis, sea-level history, and continental margin erosion. Paleoceanography, 2:1-19.

Miller, K.G., Kent, D.V., Brower, A.N., Bybell, L.M., Feigenson, M.D., Olsson, R.K., and Poore, R.Z., 1990. Eocene-Oligocene sea-level changes on the New Jersey coastal plain linked to the deep-sea record. Geol. Soc. Am. Bull., 102:331-339.

Mitchum, R.M., Sangree, J.B., Vail, P.R., and Wornardt, W.W., 1993. Recognizing sequences and systems tracts from well logs, seismic data, and biostratigraphy: examples from the late Cenozoic of the Gulf of Mexico. Weimer, P., and Posamentier, H. (Eds.), Siliciclastic Sequence Stratigraphy: Recent Developments and Applications. AAPG Mem., 58:163-197.

Mitchum, R.M., Jr., Vail, P.R., and Thompson, S., III, 1977. Seismic stratigraphy and global changes of sea level, Part 2 . The depositional sequence as a basic unit for stratigraphic analysis. In Payton, C.E. (Ed.), Seismic
Stratigraphy: Applications to Hydrocarbon Exploration. AAPG Mem., 26:53-62.

Mountain, G.S., 1987. Cenozoic margin construction and destruction offshore New Jersey. In Ross, C., and Haman, D. (Eds.), Spec. Publ. Cushman Found. Foraminiferal Res., 24:57-83.

Mountain, G.S., Miller, K.G., Blum, P., et al., 1994. Proc. ODP, Init. Repts., 150: College Station, TX (Ocean Drilling Program).

Mountain, G.S., and Tucholke, B.E., 1985. Mesozoic and Cenozoic geology of the U.S. Atlantic continental slope and rise. In Poag, C.W. (Ed.), Geologic Evolution of the United States Atlantic Margin: New York (Van Nostrand Reinhold), 293-341.

Odin, G.S., and Matter, A., 1981. Die glauconarium origine. Sedimentology, 28:611-643.

Pazzaglia, F.J., 1993. Stratigraphy, petrography, and correlation of late Cenozoic middle Atlantic Coastal Plain deposits: implications for late-stage passive-margin geologic evolution. Geol. Soc. Am. Bull., 105:16171634.

Poag, C.W., 1985. Depositional history and stratigraphic reference section for central Baltimore Canyon trough. In Poag, C.W. (Ed.), Geologic Evolution of the United States Atlantic Margin: New York (Van Nostrand Reinhold), 217-263.

Poag, C.W., and Mountain, G.S., 1987. Late Cretaceous and Cenozoic evolution of the New Jersey continental slope and upper rise: an integration of borehole data with seismic reflection profiles. In Poag, C.W., Watts, A.B., et al., Init. Repts. DSDP, 95: Washington (U.S. Govt. Printing Office), 673-724.

Poag, C.W., Watts, A.B., et al., 1987. Init. Repts. DSDP, 95: Washington (U.S. Govt. Printing Office).

Posamentier, H.W., Jervey, M.T., and Vail, P.R., 1988. Eustatic controls on clastic deposition, I: conceptual framework. In Wilgus, C.K., Hastings, B.S., Ross, C.A., Posamentier, H.W., Van Wagoner, J., and Kendall, C.G.St.C. (Eds.), Sea-Level Changes: An Integrated Approach. Spec. Publ.-Soc. Econ. Paleontol. Mineral., 42:109-124.

Posamentier, H.W., and Vail, P.R., 1988. Eustatic controls on clastic deposition, II: sequence and systems tract models. In Wilgus, C.K., Hastings, B.S., Ross, C.A., Posamentier, H.W., Van Wagoner, J., and Kendall, C.G.St.C. (Eds.), Sea-Level Changes: An Integrated Approach. Spec. Publ_-Soc. Econ. Paleontol. Mineral., 42:125-154.

Pratson, L.F., Ryan, W.B.F., Mountain, G.S., and Twichell, D.C., 1994. Submarine canyon initiation by downslope-eroding sediment flows: evidence in late Cenozoic strata on the New Jersey slope. Geol. Soc. Am. Bull., $106: 395-412$

Reynolds, D.J., Steckler, M.S., and Coakley, B.J., 1991. The role of the sediment load in sequence stratigraphy: the influence of flexural isostasy and compaction. J. Geophys. Res., 96:6931-6949.

Robb, J.M., Hampson, J.C., Jr., and Twichell, D.C., 1981. Geomorphology and sediment stability of a segment of the U.S. continental slope off New Jersey. Science, 211:935-937.

Robb, J.M., Kirby, J.R., Hampson, J.C., Jr., Gibson, P.R., and Hecker, B., 1983. Furrowed outcrops of Eocene chalk on the lower continental slope offshore New Jersey. Geology, 11:182-186.

Ryan, W.B.F., 1991. Results of an experiment in ground truth calibration of some imagery on the continental slope, off-shore New Jersey. Eos, $72: 165$.

Schlee, J.S., 1981. Seismic stratigraphy of Baltimore Canyon Trough. AAPG Bull., 65:26-53.

Schlee, J.S., Dillon, W.P., and Grow, J.A., 1979. Structure of the continental slope off the eastern United States. Spec. Publ.-Soc. Econ. Paleontol. Mineral. 27:95-117.

Schlee, J.S., and Robb, J.M., 1991. Submarine processes of the middle Atlantic continental rise based on GLORIA imagery. Geol. Soc. Am. Bull., 103:1090-1113.

Shanmugam, G., and Benedict, G.L., 1978. Fine-grained carbonate debris flow, Ordovician basin margin, Southern Appalachians. J. Sediment. Petrol., 48:1233-1240.

Shanmugam, G., Bloch, R.B., Mitchell, S.M., Beamish, G.W.J., Hodgkinson, R.J., Damuth, J.E., Straume, T., Syvertsen, S.E., and Shields, K.E. 1995. Basin-floor fans in the North Sea: sequence-stratigraphic models vs. sedimentary facies. AAPG Bull., 79:477-512.

Shanmugam, G., Lehtonen, L.R., Straume, T., Syversten, S.E., Hodgkinson, R.J., and Skibeli, M., 1994. Slump and debris flow dominated upper slope facies in the Cretaceous of the Norwegian and Northern North Seas $\left(61^{\circ}-67^{\circ}\right)$ : implications for sand distribution. AAPG Bull., 78:910-937. 
Singer, A., 1984. The paleoclimatic interpretation of clay minerals in sediments: a review. Earth-Sci. Rev., 21:251-293.

Tucholke, B.E., and Vogt, P.R., 1979. Western North Atlantic: sedimentary evolution and aspects of tectonic history. In Tucholke, B.E., Vogt, P.R., et al., Init. Repts. DSDP, 43: Washington (U.S. Govt. Printing Office), 791-825.

Twichell, D.C., 1986. Geomorphic map of the U.S. Atlantic continental margin and upper rise between Hudson and Baltimore Canyons. In Folger, D.W., and Hathaway, J.C. (Eds.), Conference on Continental Margins Mass Wasting and Pleistocene Sea-level Changes, August 13-15, 1980. Geol. Surv. Circ. (U.S.), 961:14-21.

Vail, P.R., 1987. Seismic stratigraphy interpretation using sequence stratigraphy, Part 1. Seismic stratigraphy interpretation procedure. In Bally, A.W. (Ed.), Atlas of Seismic Stratigraphy (Vol. 1). AAPG Stud. Geol., 27:1-10.

Vail, P.R., Audemard, F., Bowman, S.A., Eisner, P.N., and Perez-Cruz, G., 1991. The stratigraphic signatures of tectonics, eustasy, and sedimentology - an overview. In Einsele, G., Ricken, W., and Seilacher, A. (Eds.), Cycles and Events in Stratigraphy: Berlin (Springer), 617-659.

Vail, P.R., Mitchum, R.M., Jr., and Thompson, S., III, 1977. Seismic stratigraphy and global changes of sea level, Part 4. Global cycles of relative changes of sea level. In Payton, C.E. (Ed.), Seismic Stratigraphy: Applications to Hydrocarbon Exploration. AAPG Mem., 26:83-97.

Van Wagoner, J.C., Mitchum, R.M., Campion, K.M., and Rahmanian, V.D., 1990. Siliciclastic Sequence Stratigraphy in Well Logs, Cores, and Out- crops: Concepts for High-Resolution Correlation of Time and Facies. AAPG Methods Explor. Ser., 7.

Varnes, D.J., 1958. Landslide types and processes. In Eckel, E.D. (Ed.), Landslide and Engineering Practice. Highway Res. Board Spec. Rep., 29:20-47.

Vassallo, K., Jacobi, R.D., and Shor, A., 1983. Echo character, microphysiography and geological hazards. In Ewing, J.I., and Rabinowitz, P.H. (Eds.), ODM, Regional Data Synthesis Series Atlas I, Eastern North American Continental Margin and Adjacent Ocean Floor, $34^{\circ}$ to $41^{\circ} \mathrm{N}$ and $68^{\circ}$ to $78^{\circ} \mathrm{W}$ : Washington (JOI), Map \#31.

von Rad, U., and Botz, R., 1987. Diagenetic Fe-Mn carbonates in Cretaceous and Tertiary sediments of the continental rise off eastern North America, Deep Sea Drilling Project Site 603. In van Hinte, J.E., Wise, S.W., Jr., et al., Init. Repts. DSDP, 93 (Pt. 2): Washington (U.S. Govt. Printing Office), 1061-1077.

Woodcock, N.H., 1976. Structural style in slump sheets: Ludlow Series, Powys, Wales. J. Geol. Soc. London, 132:399-415.

, 1979. Sizes of submarine slides and their significance. J. Struct. Geol., 1:137-142.

Date of initial receipt: 2 March 1995

Date of acceptance: 28 November 1995

Ms 150SR-016 